\title{
Recovery of benthic marine communities from the end-Permian mass extinction at the low latitudes of eastern Panthalassa
}

Hofmann, Richard ; Hautmann, Michael ; Brayard, Arnaud ; Nützel, Alexander ; Bylund, Kevin G ; Jenks, James F ; Vennin, Emmanuelle ; Olivier, Nicolas ; Bucher, Hugo

DOI: https://doi.org/10.1111/pala.12076

Posted at the Zurich Open Repository and Archive, University of Zurich ZORA URL: https://doi.org/10.5167/uzh-84501

Journal Article

Originally published at:

Hofmann, Richard; Hautmann, Michael; Brayard, Arnaud; Nützel, Alexander; Bylund, Kevin G; Jenks, James F; Vennin, Emmanuelle; Olivier, Nicolas; Bucher, Hugo (2014). Recovery of benthic marine communities from the end-Permian mass extinction at the low latitudes of eastern Panthalassa. Palaeontology, 57(3):547-589.

DOI: https://doi.org/10.1111/pala.12076 


\title{
RECOVERY OF BENTHIC MARINE COMMUNITIES FROM THE END-PERMIAN MASS EXTINCTION AT THE LOW LATITUDES OF EASTERN PANTHALASSA
}

\author{
by RICHARD HOFMANN ${ }^{1 *}$, MICHAEL HAUTMANN $^{1}$, ARNAUD BRAYARD ${ }^{2}$, \\ ALEXANDER NÜTZEL ${ }^{3}$, KEVIN G. BYLUND ${ }^{4}$, JAMES F. JENKS ${ }^{5}$, \\ EMMANUELLE VENNIN ${ }^{2}$, NICOLAS OLIVIER ${ }^{6}$ and HUGO BUCHER ${ }^{1}$ \\ ${ }^{1}$ Paläontologisches Institut und Museum, Universität Zürich, 8006, Zürich, Switzerland; e-mails: richard.hofmann@pim.uzh.ch, michael.hautmann@pim.uzh.ch, \\ hugo.fr.bucher@pim.uzh.ch \\ ${ }^{2}$ UMR CNRS 6282 Biogéosciences, Université de Bourgogne, 6 boulevard Gabriel, 21000, Dijon, France; e-mails: arnaud.brayard@u-bourgogne.fr, \\ emmanuelle.vennin@u-bourgogne.fr \\ ${ }^{3}$ SNSB-Bayerische Staatssammlung für Paläontologie und Geologie, Department of Earth and Environmental Sciences, Palaeontology and Geobiology, \\ GeoBio-Center LMU, Richard-Wagner-Str. 10, 80333, München, Germany; e-mail: a.nuetzel@lrz.uni-muenchen.de \\ ${ }^{4} 140$ South 700 East, Spanish Fork, UT 84660, USA; e-mail: kevin@ammonoid.com \\ ${ }^{5} 1134$ Johnson Ridge Lane, West Jordan, UT 84084, USA; e-mail: jenksjimruby@comcast.net \\ ${ }^{6}$ Laboratoire de Géologie de Lyon: Terre, Planètes, Environnement, UMR CNRS 5276, Université Lyon 1, Boulevard du 11 Novembre 1918, 69622, Villeurbanne \\ Cedex, France; e-mail: nicolas.olivier@univ-lyon1.fr \\ ${ }^{\star}$ Corresponding author
}

Typescript received 13 June 2013; accepted in revised form 26 August 2013

Abstract: Based on the quantitative community analysis using species-level identifications, we track the restoration of benthic ecosystems after the end-Permian mass extinction throughout the Lower Triassic of the western USA. New data on the palaeoecology of the Thaynes Group and Sinbad Formation are provided, which fill a gap between the recently studied palaeoecology of the Griesbachian-Dienerian Dinwoody Formation and the Spathian Virgin Formation. In the Sinbad Formation and Thaynes Group, 17 species (12 genera) of bivalves, 7 species and genera of gastropods and 2 species and genera of brachiopods are recognized. The new bivalve genus Confusionella (Pteriidae) is described. A comprehensive review of the whole Lower Triassic succession of benthic ecosystems of the western USA indicates that midand inner shelf environments show incipient recovery signals around the Griesbachian-Dienerian transition, during the Smithian and, most profound, during the early Spathian. Ecological data from youngest strata of the Dinwoody Formation as well as stratigraphic ranges of species suggest that the late Dienerian was likely a time interval of environmental stress for benthic ecosystems. Despite some evidence for short-term environmental disturbances (e.g. shift of dominant taxa, transient drop in alpha-diversity) during the Smithian-Spathian transition, benthic ecosystems did not show any notable taxonomic turnover at that time, in contrast to the major crisis that affected ammonoids and conodonts. Whereas alpha-diversity of benthic communities generally increased throughout the Early Triassic, beta-diversity remained low, which reflects a persistently wide environmental range of benthic species. This observation is in accordance with a recently proposed model that predicts a time lag between increasing within-habitat diversity (alphadiversity) and the onset of taxonomic differentiation between habitats (beta-diversity) during biotic recoveries from mass extinction events. The observation that beta-diversity had not significantly increased during the Early Triassic might also provide an explanation for the comparably sluggish increase in benthic diversity during that time, which has previously been attributed to persistent environmental stress.

Key words: recovery, benthic ecosystems, Thaynes, Sinbad, palaeoecology, diversity.
RECENT studies (Krystyn et al. 2003; Brayard et al. 2009; Hautmann et al. 2011, 2013; Hofmann et al. 2011, 2013a) provided evidence that the recovery from the end-Permian mass extinction was more volatile than traditionally portrayed (Hallam 1991; Schubert and Bottjer 1995; Twitchett and Wignall 1996), suggesting that ecosystems suffered from several short-term environmental perturbations during the Early Triassic rather than from long-lasting environmental stress. Furthermore, it has been suggested that intrinsic aspects (Schubert and Bottjer 1995), most notably reduced interspecific competition, had an important impact on the pace of recovery 
(Hofmann et al. 2013a, b). The Lower Triassic of the western USA provides one of the best records of Early Triassic benthic ecosystems worldwide, which facilitates tracing benthic recovery from the end-Permian mass extinction through different time slices, represented by comparable sets of habitats from the same palaeogeographical region. In previous papers (Hautmann et al. 2013; Hofmann et al. 2013a, b), we re-evaluated the taxonomy and palaeoecology of the Griesbachian-Dienerian and the Spathian faunas from the western USA. Here, we add data on Smithian - early Spathian benthic palaeocommunities of the same region. Collectively, these data allow us to draw a complete picture of the recovery of benthic marine ecosystems at the eastern Panthalassa margin. We thereby address the question of intrinsic and extrinsic controls of recovery and test a previously proposed model (Hofmann et al. 2013b) on changes in diversity partitioning during rediversification after major diversity depletions.

\section{GEOLOGICAL AND STRATIGRAPHICAL SETTING OF THE THAYNES GROUP AND THE SINBAD FORMATION}

The Thaynes Group is today exposed over an area stretching from southern Wyoming, eastern and central Idaho, Utah and north-eastern Nevada. It represents a relatively shallow epicontinental marine embayment of the eastern Panthalassa Ocean (Fig. 1). The Thaynes Group reaches a thickness of about $1000 \mathrm{~m}$ in its depot centre (western Utah and south-eastern Idaho, own observation HB) and pinches out towards the south, east and west. The Thaynes Group records generally epicontinental open marine deposits composed of alternating shale, marl, siltstone and limestone (Figs 2, 3A). These strata result from a major transgression reaching its maximum extent during the late Smithian (Collinson and Hasenmueller 1978; Carr and Paull 1983; Paull and Paull 1993). Lucas et al. (2007) proposed raising the Thaynes Formation to Group

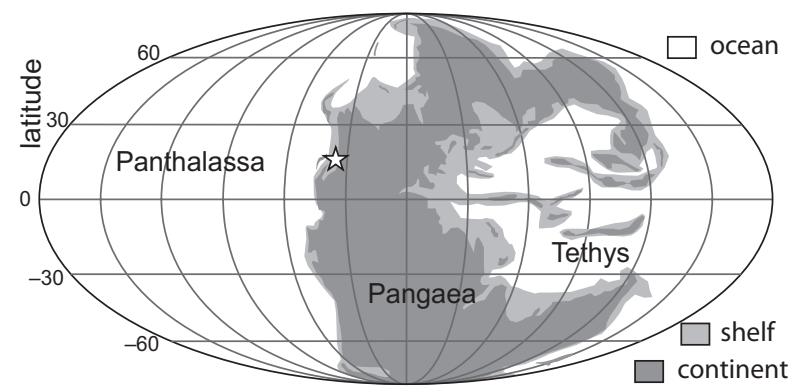

FIG. 1. Palaeogeographical position of the Thaynes Group and Sinbad Formation (star) during the Early Triassic (map after Blakey 2012). status in which he also included shallow and marginal marine deposits of the Sinbad and Virgin Formation (Fig. 2). However, as already noted by Hofmann et al. $(2013 b)$, the typical lithologies of both formations are exclusively developed in southern Utah where they are easily recognized within the Moenkopi Group (as proposed by Poborsky, 1954, and endorsed by Lucas et al. 2007). To retain nomenclatural consistency with respect to the Sinbad Formation and the Virgin Formation, we follow Lucas et al. (2007) and refer to the Thaynes Group for clearly marine Lower Triassic strata of the Confusion Range, and we extend its use into the Pahvant Range and Mineral Mountains. The Sinbad Formation of southern Utah is mainly composed of bioclastic limestones, calcareous sandstones and dolomites deposited in inner shelf and marginal marine settings. It roughly delineates the maximum coastal onlap of marine strata during the Smithian in southern Utah.

Smithian outcrops in Utah generally contain abundant fossils, but no detailed regional biostratigraphic zonation has been proposed for this substage. All previous dates obtained from macrofossils are based on ammonoids with the twofold subdivision suggested by Kummel and Steele (1962): the Meekoceras gracilitatis Zone and the Anasibirites kingianus Zone, in the ascending order. However, Brayard et al. (2009) and Stephen et al. (2010) recently demonstrated that these zones represent only the middle and late Smithian and can be subdivided into more precise different subzones and beds. Based on new ammonoid faunas, older Smithian deposits also occur within some restricted areas. Therefore, we use a new ammonoid biozonation (Fig. 3B; Brayard et al. 2011, 2013).

\section{FIELD LOCALITIES AND METHODS}

Fieldwork was conducted in October 2009 (by RH, AB, $\mathrm{KB}, \mathrm{JJ})$ in the area of the Pahvant Range and the Confusion Range. In June 2011, we ( $\mathrm{RH}, \mathrm{MH}, \mathrm{AB}, \mathrm{JJ}, \mathrm{KB}, \mathrm{EV}$, NO) investigated sections in the Mineral Mountains, the San Rafael Swell and the Torrey area (see Table 1 for detailed geographical information). Bed-by-bed logging was carried out at five sections of the Thaynes Group and two sections of the Sinbad Formation. Fossils were collected from discrete limestone and calcareous sandstone beds by mechanically decomposing large blocks and quantitative sampling for identifiable specimens. In shale intervals, fossils were representatively sampled by collecting from float material. If necessary, standard invertebrate preparation techniques were carried out to facilitate systematic examination. Beds showing evidence of reworking (e.g. notable size sorting, gradation and strong fossil abrasion) were not included in the analysis. Sampling of each 


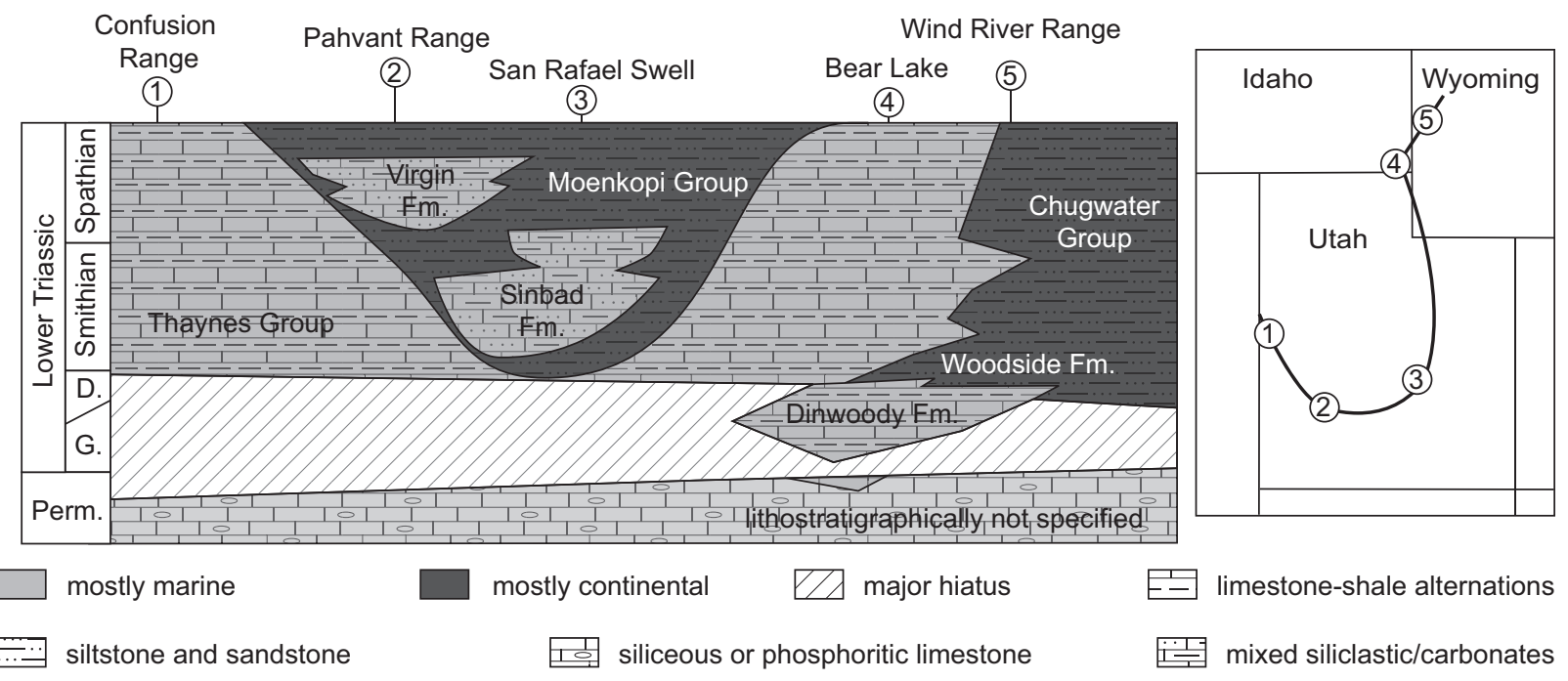

FIG. 2. Principle lithostratigraphical relationships of upper Permian with lower Spathian rocks of Utah, Wyoming and Idaho. Several formations that are recognized in the marginal marine to continental siliciclastic facies of the Moenkopi group were omitted to enhance readability. The scheme rests on visualizations and data provided by Blakey (1974), Clark and Carr (1984), Cavaroc and Flores (1991) as well as own observations. Vertical dimensions are not to scale with actual time or thickness. D., Dienerian; G., Griesbachian; Perm., Permian; Fm., Formation.

bed was conducted until more than 100 specimens were obtained or until additional collecting did not result in finding new taxa. However, some outcrop conditions did not allow for comprehensive sampling.

Sedimentological analysis was mainly based on macroscopic criteria in the field. Taxa recognized herein include bivalves, gastropods and brachiopods. Abundance data of the samples were analysed with PAST, version $2.17 \mathrm{c}$ (Hammer et al. 2001), using unweighted paired group Qmode cluster analysis. The Morisita index of similarity (Morisita 1959) was used as distance measure, which has been recommended for palaeoecological data (Hammer and Harper 2006). This procedure has been applied successfully in Hofmann et al. $(2013 a, b)$ to detect recurrent assemblages of taxa in comparable data sets. All subclusters and respective samples with a Morisita similarity approximately higher than 0.4 were pooled into associations (Aberhan 1992). These new species-abundance data were then used to compute ranked species abundance, trophic nuclei, ecological pie charts and rarefaction analysis. The trophic nucleus is represented by those species that contribute to at least 80 per cent of total specimen number per association (Neyman 1967). Taxonomic evenness of samples is given as dominance index D as obtained from PAST (Hammer et al. 2001).

Diversity partitioning is analysed at the withincommunity level (alpha-diversity) and betweencommunity level (beta diversity). Sepkoski (1988) defined alpha-diversity as the species richness in a single locality or sample. Alternatively, Whittaker (1972) understood alpha-diversity as the number of species in a given area or community. Sample richness (alpha-diversity sensu Sepkoski 1988), is herein referred to as species richness (of a sample). Cluster analysis was used to reconstruct communities based on recurrent associations of species. Accordingly, we use alpha-diversity to describe the bulk diversity of merged samples that constitute an association as an approximation of a palaeocommunity. A single bed would represent an incomplete sample of such a palaeocommunity and, thus, would highly underestimate the alpha-diversity. Beta-diversity is a measure for the taxonomic differentiation between-community (beta-diversity) level, following the original concept of Whittaker (1972, 1977). Some subsequent studies used sample diversity rather than community diversity as 'alpha-diversity' (Bambach 1977; Sepkoski 1988), which has the advantage that it does not depend on the somewhat subjective identification of recurrent assemblages and (probably more important) that it is much less timeconsuming. However, sample diversity is also subjective in the sense that it represents a random fraction from the bulk of palaeontologically identifiable organisms in the palaeocommunity/association, depending on the local conditions at the given sampling point. Additionally, sample or point diversity does not represent a natural ecological entity, as the community does. We therefore prefer using alpha-diversity in the original sense, and we minimalize the subjective aspect of palaeocommunity identification by combining cluster analyses of palaeontological samples with sedimentological data for habitat discrimination. However, sample diversity is additionally discussed in the analyses of temporal and spatial trends. 

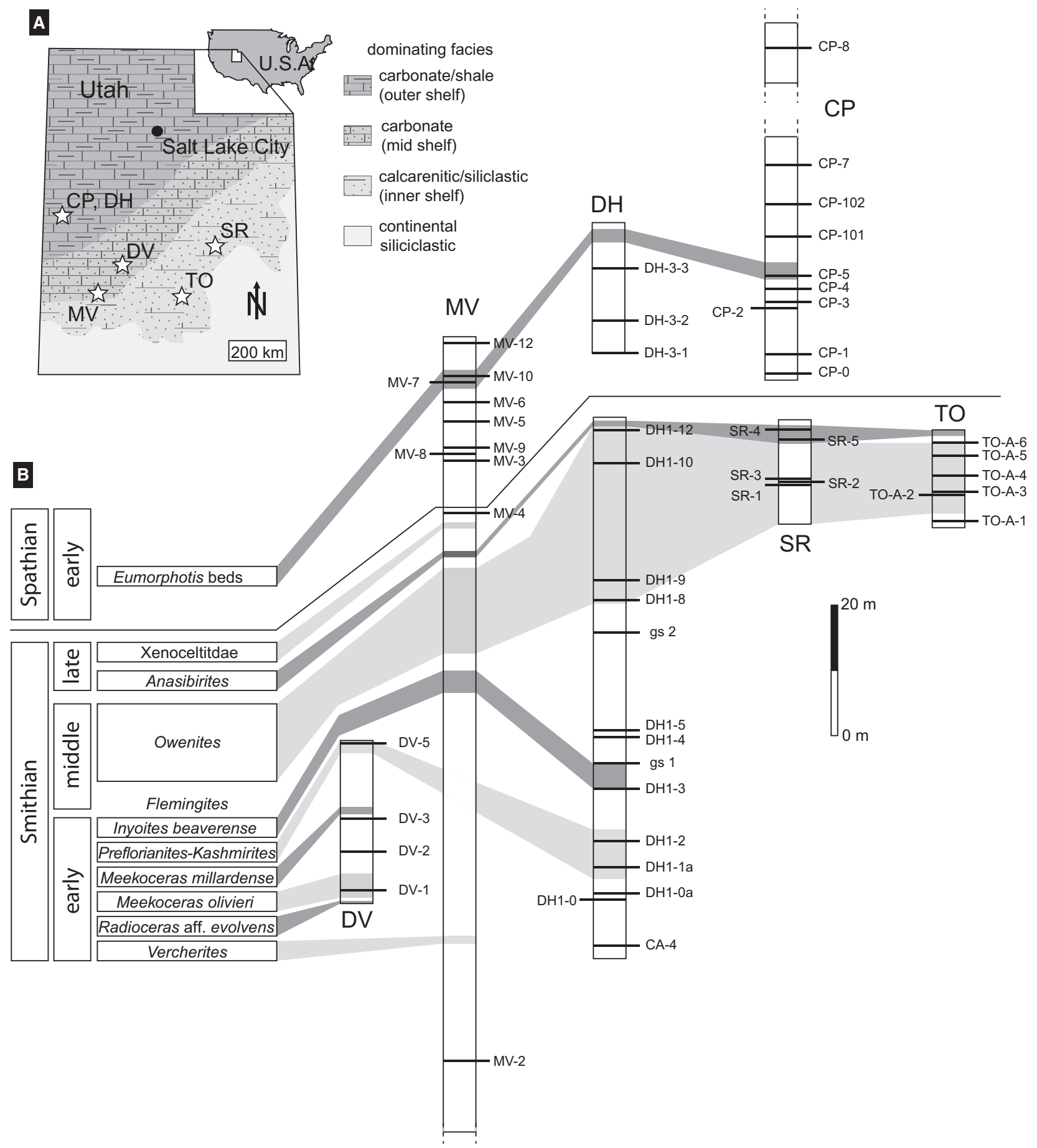

FIG. 3. A, map of the studied sections and their approximate palaeogeographical relationships as indicated by predominating facies types (CP, Cowboy Pass; DH, Disappointment Hills; MV, Mineral Mountains/Minersville; DV, Dog Valley; TO, Torrey; SR, San Rafael Swell). B, stratigraphic correlation of the investigated sections showing the position of the sampled intervals.

Our basic measure of alpha-diversity is species richness, whereas beta-diversity (between associations/habitat diversity) is measured by the mean minimum beta-diversity approach proposed by Hofmann et al. (2013a). Data for this paper, including an Excel file with data sheets showing the full lists of species occurrences, associations and computed alpha- and beta-diversities, are available in the Dryad digital repository (Hofmann et al. 2013c). 
TABLE 1. Geographical information on the logged sections.

\begin{tabular}{llll}
\hline Code & Section & Geographical Information & GPS coordinates (WGS 84) \\
\hline DH-1 & Disappointment Hills 1 & Confusion Range, Utah & $39^{\circ} 24^{\prime} 42.42^{\prime \prime} \mathrm{N}, 113^{\circ} 41^{\prime} 22.23^{\prime \prime} \mathrm{W}$ \\
DH-3 & Disappointment Hills 3 & Confusion Range, Utah & $39^{\circ} 24^{\prime} 52.20^{\prime \prime} \mathrm{N}, 113^{\circ} 40^{\prime} 50.00^{\prime \prime} \mathrm{W}$ \\
CP & Cowboy Pass & Confusion Range, Utah & $39^{\circ} 20^{\prime} 23.55^{\prime \prime} \mathrm{N}, 113^{\circ} 41^{\prime} 43.79^{\prime \prime} \mathrm{W}$ \\
DV & Dog Valley & Pahvant Range, Utah & $38^{\circ} 40^{\prime} 22.80^{\prime \prime} \mathrm{N}, 112^{\circ} 31^{\prime} 18.20^{\prime \prime} \mathrm{W}$ \\
MV & Minersville & Mineral Mountains, Utah & $38^{\circ} 13^{\prime} 43.00^{\prime \prime} \mathrm{N}, 112^{\circ} 53^{\prime} 17.40^{\prime \prime} \mathrm{W}$ \\
SR & Sand Rafael Swell & Central Emery County, Utah & $38^{\circ} 59^{\prime} 49.29^{\prime \prime} \mathrm{N}, 110^{\circ} 40^{\prime} 44.26^{\prime \prime} \mathrm{W}$ \\
TO & Torrey & West Wayne County, Utah & $38^{\circ} 16^{\prime} 20.00^{\prime \prime} \mathrm{N}, 111^{\circ} 23^{\prime} 5.30^{\prime \prime} \mathrm{W}$ \\
\hline
\end{tabular}

\section{AGE AND SEDIMENTARY ENVIRONMENTS OF THE INVESTIGATED SECTIONS}

\section{Confusion Range}

The sampled part of the Disappointment Hills sections includes strata of the Smithian (DH-1, Fig. 4A) and the lowermost Spathian (DH-3, Fig. 4B). Some fossil specimens included in the systematic analysis come from a sampling point called DH-2B of the Disappointment Hills locality. Here, strata are poorly exposed, but ammonoids suggest an early-to-middle Smithian age. The base of the section DH-1 is composed of cherty limestones of the Middle Permian Gerster Formation. The transition to the Triassic is complex. Discontinuous upper surfaces of limestone beds and the presence of breccias, conglomerates and some poorly exposed red beds suggest a complex history of episodes with emersion, erosion and nondeposition. The age of the massive calcarenites above the Permian hiatus is uncertain, but these beds may correspond to Lower Triassic strata. Above this interval, the section DH-1 is mainly composed of olive-to-brown shales and marls alternating with fossiliferous packstone and grainstone beds. Abundant ammonoids allow a precise correlation with Smithian ammonoid zones (Fig. 3). The shale intervals (Fig. 5A) were deposited out of suspension in quiet waters of the outer shelf region. The packstone- and grainstone-associated facies are indicative of storm-induced conditions deposited around the mid-/ outer shelf transition as evidence for active wave reworking (e.g. cross-bedding, ripple cross-lamination) is absent. The overall presence of ammonoids in the section DH-1 indicates an open marine setting. A covered shaly interval with an estimated thickness of about $50 \mathrm{~m}$ separates sections DH-1 and DH-3. The latter section is mainly composed of laminated greenish shales with thin mudstone beds. The section is topped by a series of medium-bedded bioclastic limestone beds (Fig. 5B) with large bivalves of the genus Eumorphotis, which are frequently observed in life position. These beds are widespread in the study area and mark the transition to the Spathian as they characteristically occur between the youngest Smithian and the oldest Spathian (Bajarunia confusionensis beds, Guex et al. 2010) ammonoid zones (Fig. 3). They typically consist of bioclastic grainstone and rudstone and are intercalated with thin marlstones. These beds are poorly sorted and show no evidence of gradation. We suggest that they represent proximal storm deposits, which were colonized by large epifaunal bivalves during quiet phases. Accordingly, they most likely represent deposits of the middle shelf, between the mean fair weather wave base and the storm wave base. The same type of deposits are also recorded in the section at Cowboy Pass section (CP; Fig. 4D) and is herein used as a marker that allows for a continuous correlation of the Thaynes Group throughout the Confusion Range. At Cowboy Pass, the ensuing interval is characterized by red and purple siltstones and claystones, which are interbedded with some thin beds of packstone and grainstone (Fig. 5C). Some levels that exhibit ripple cross-laminated fine-grained sandstones showing some mud drapes suggest deposition in marginal marine and probably tidally influenced settings. The absence of stenohaline organisms such as crinoids and brachiopods, which both became abundant in Spathian deposits of the western USA (Schubert and Bottjer 1995; Hofmann et al. $2013 b$ ), supports a restricted marginal marine setting. The first late early Spathian-aged ammonoid faunas (Guex et al. 2010) and first abundant crinoidal debris suggesting an open marine setting are observed further upsection (c. $100 \mathrm{~m}$ above the Eumorphotis beds). These beds did not yield abundant benthic fauna. The section continues with outer shelf marls and shales, which are very poorly exposed and, thus, were not further investigated.

\section{Pahvant Range}

The base of the section at Dog Valley (DV, Fig. 4C) is composed of calcareous siltstones and marly mudstones (Fig. 5D), which record early Smithian ammonoid faunas (Radioceras aff. evolvens beds). It is suggested that these strata record open marine conditions of a mid- to outer shelf setting. The overlying interval is composed of shales and marls indicative of an outer shelf facies. Overlying the shales and marls is an interval of compact marly and 


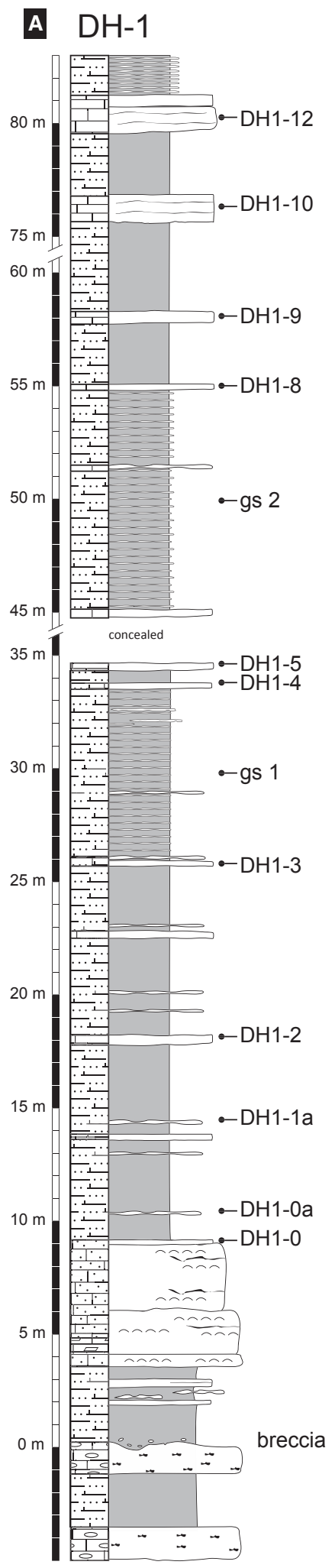

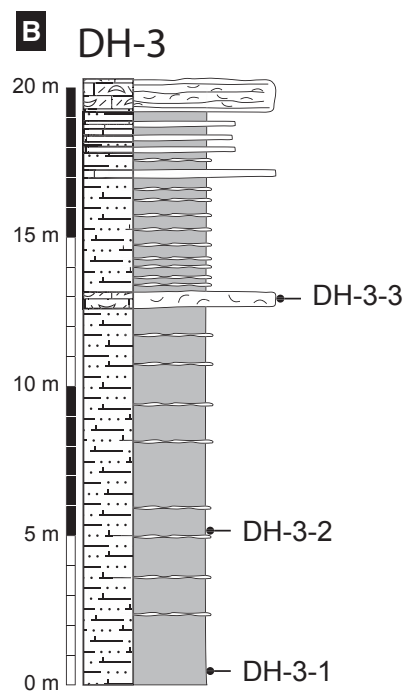
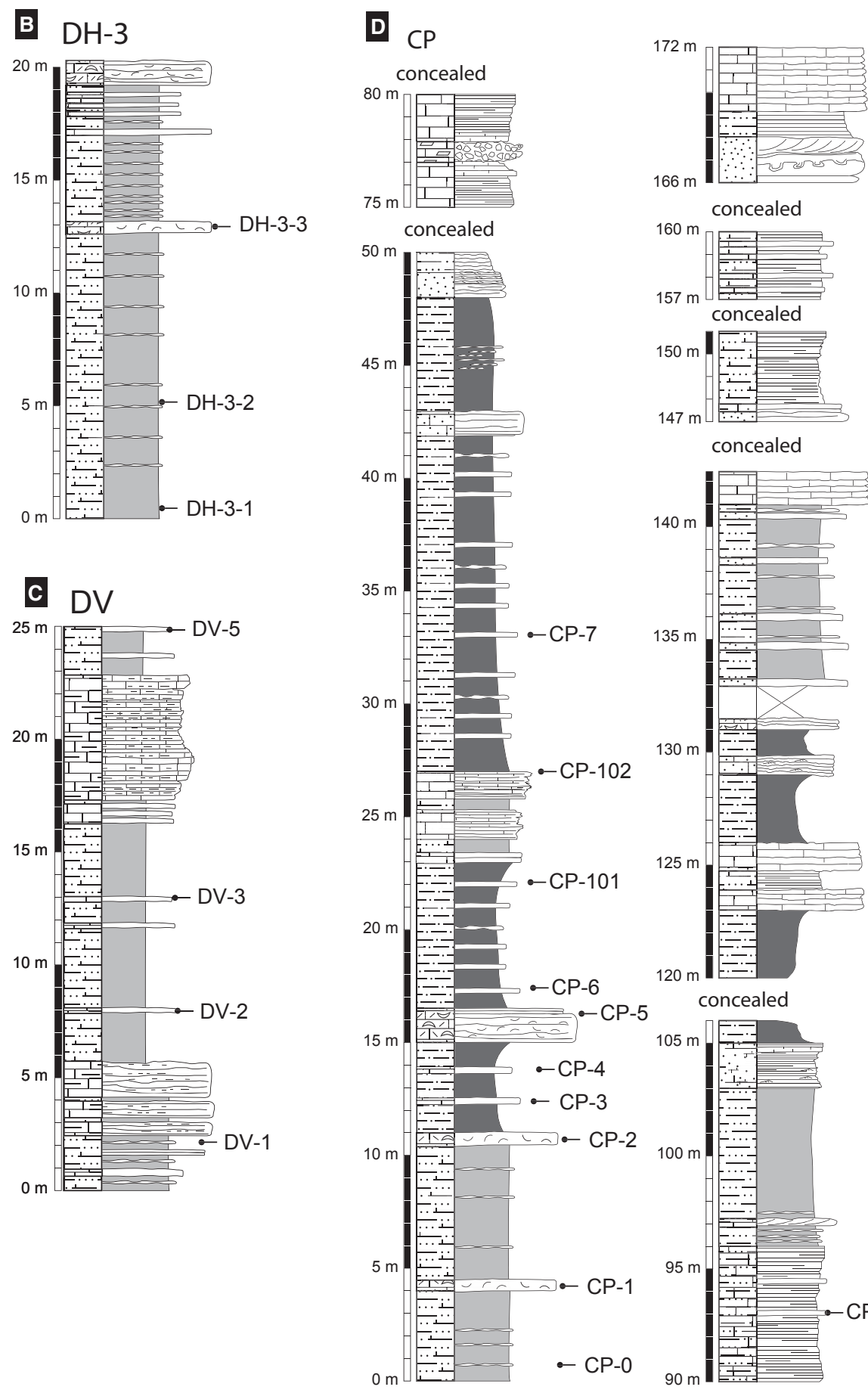

Lithology

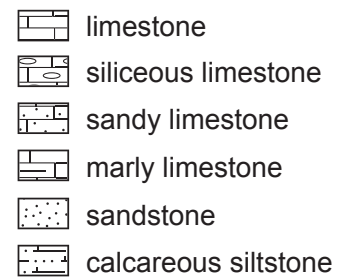

$\because \because$ calcareous sandstone

olive-grey marls/siltstone

marginal marine/

terrestrial red beds

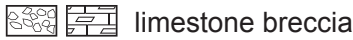

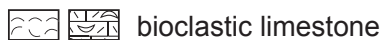
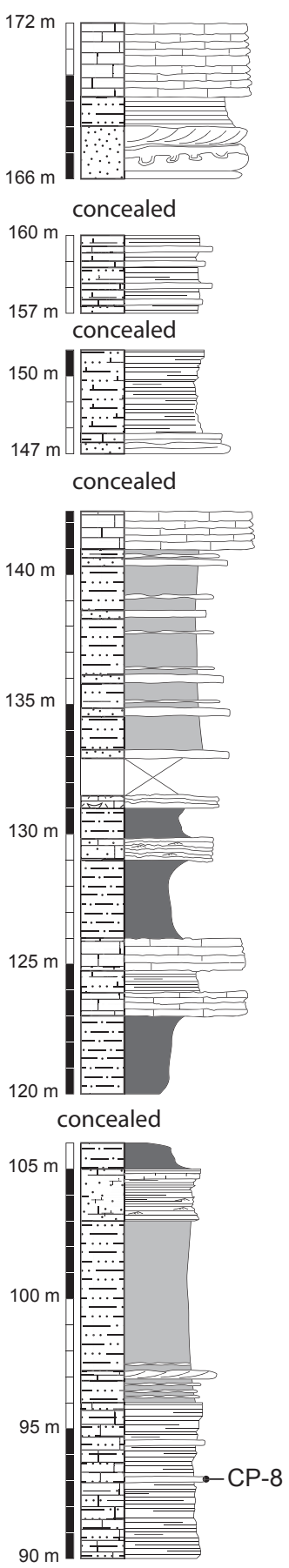

concealed

concealed

$140 \mathrm{~m}$

concealed

Bedding

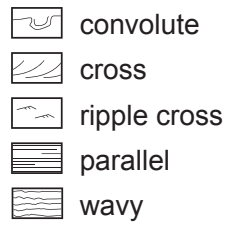

FIG. 4. Sections of the Thaynes Group. A, Disappointment Hills 1. B, Disappointment Hills 2. C, Dog Valley. D, Cowboy Pass. 

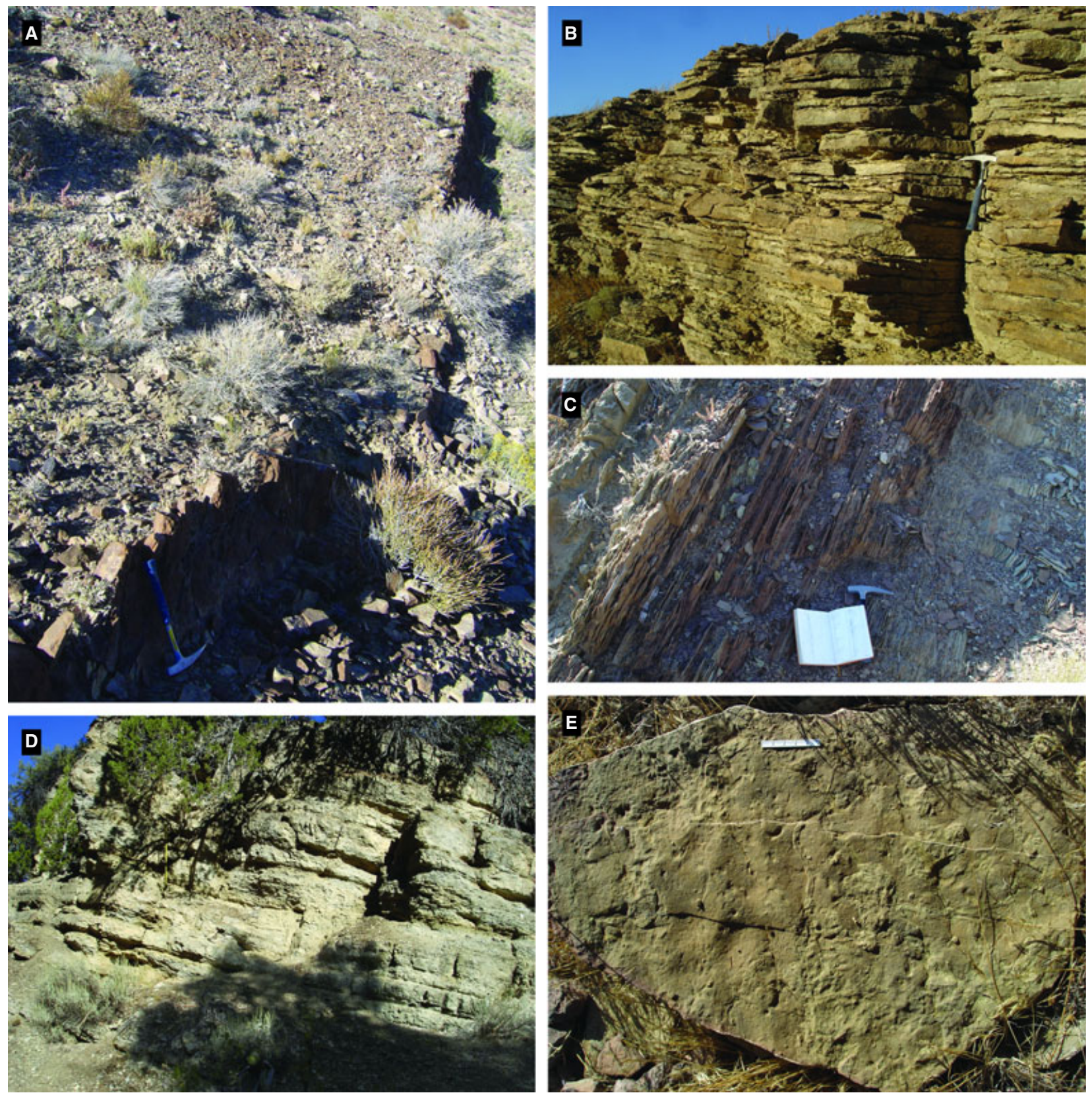

FIG. 5. Field photographs of the Thaynes Group. A, claystone and siltstone intercalated with thin limestone beds of DH-1. Hammer for scale represents $35 \mathrm{~cm}$. B, bioclastic grainstones of the 'Eumorphotis-beds'. Top of section DH-3. Hammer for scale represents $35 \mathrm{~cm}$. C, overturned, thinly bedded to laminated siltstones and claystones intercalated between thin bioclastic limestone around the Smithian Spathian transition of CP section. Fieldbook for scale represents $20 \mathrm{~cm}$. D, lower part of DV section exposing a marly limestone succession. The height of exposure is about $3 \mathrm{~m}$. E, fine-grained sandstone of the upper part of section showing oscillation ripples in upper bedding-plane view. Note the sparse bioturbation. Scale bar represents $5 \mathrm{~cm}$.

sandy limestones with abundant bedding-plane horizontal bioturbation, and occasionally, intercalated beds showing oscillation ripples (Fig. $5 \mathrm{E}$ ) are indicative of shallow water. The top of the section shows the same lithologies of alternating shale and storm-induced limestone beds as observed in the section DH-1, suggesting a mid- to outer shelf setting.

\section{Mineral Mountains}

The base of the section (MV, Fig. 6) is dominated by red beds of terrestrial and probable marginal marine origin (Fig. 7A). The first thick carbonate complex is composed of limestone with brecciated horizons, microbial lamination and bird's-eye structures (Fig. 7B), which are indica- 


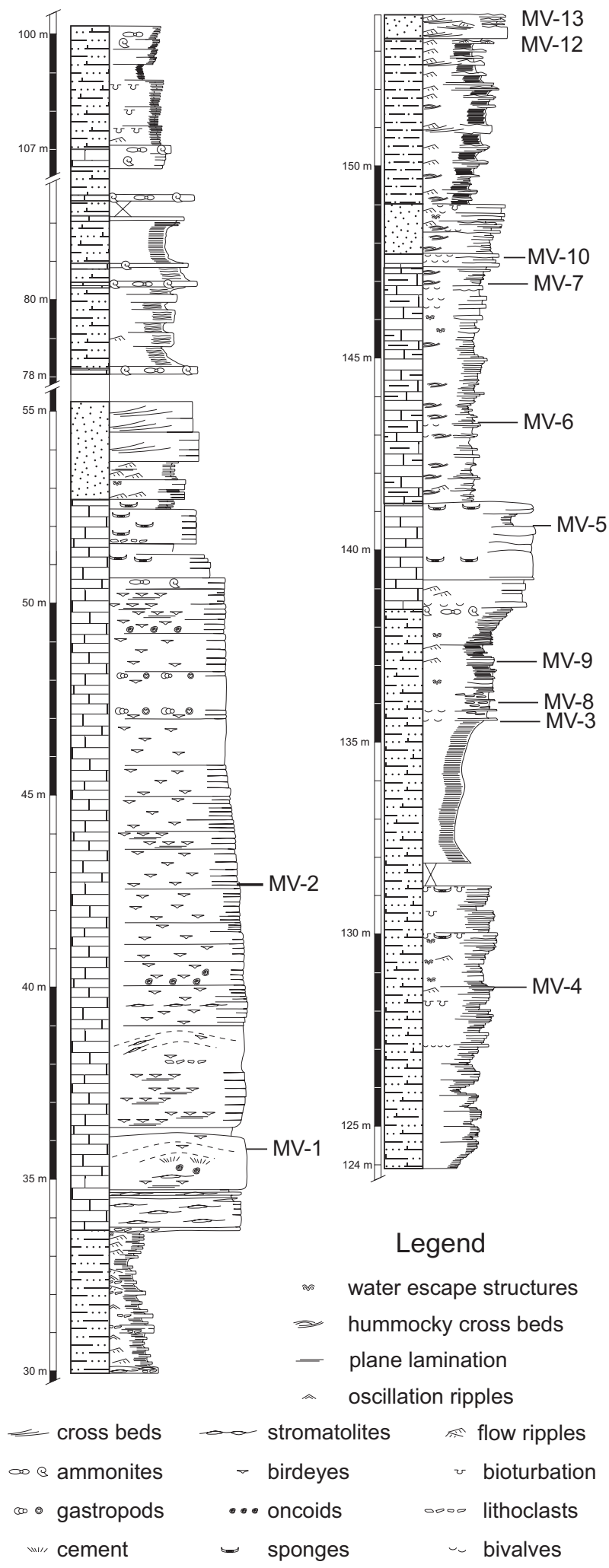

FIG. 6. Sections of the Thaynes Group, Mineral Mountains/ Minersville. tive of a very shallow, restricted marine settings. The top of this complex consists of a microbe-sponge bioherm complex (Brayard et al. 2011) that hosts an abundant marine fauna including ammonoids, thus suggesting a deeper, open marine environment. The overlying interval is characterized by a succession of calcarenitic beds showing bidirectional cross-bedding and mud drapes indicative of a strong tidal influence. The ensuing part of the section (Fig. 7A) records the typical outer shelf facies of the Thaynes Group with intercalated shales and storm-induced limestones. This succession is capped by two occurrences of microbesponge bioherms (Fig. 7E). The upper part of the section is composed of siltstones and marls with abundant ripple cross-bedding (Fig. 7D) and small-scale hummocky crossbedding, being suggestive for an upper mid- to inner shelf setting. These beds are intercalated with bioclastic grainstone and rudstone (Fig. 7C) very similar to the Eumorphotis beds of the Confusion Range. The remainder of the section is represented by marginal marine and continental red beds. The oldest fossiliferous bed, which has been included in the analysis, is recorded $18 \mathrm{~m}$ below the oldest recorded ammonoid zone of the early Smithian (Figs 3B, 6). All sampled beds from the upper part of the section (samples MV-4 to MV-12) represent the SmithianSpathian transition and the lowermost Spathian.

\section{San Rafael Swell}

A recent overview on the stratigraphy and sedimentary facies of the Sinbad Formation in the San Rafael Swell (Fig. 8B) is presented in Nützel and Schulbert (2005) and Goodspeed and Lucas (2007). The Sinbad Formation reaches a thickness of about $20 \mathrm{~m}$ in the study area and is mainly composed of some mixed carbonate-siliciclastic lithologies of inner shelf settings including carbonate shoals, tidal flats, backshore lagoons and shallow subtidal open marine environments (Goodspeed and Lucas 2007). Our sampled section was previously studied by Batten and Stokes (1986), Nützel and Schulbert (2005) and Goodspeed and Lucas (2007). The sedimentary facies inferred in these studies is largely supported by our observations (Fig. 9A-D). All samples were derived from beds indicating high-energy, shallow marine deposition. However, the sampled horizons adequately represent the palaeocommunities because of a good state of preservation, articulation of bivalves and wide spectrum of clast sizes arguing against size sorting (Hautmann and Nützel 2005; Nützel and Schulbert 2005). Preliminary lithostratigraphical correlations and sparse ammonoid data suggest that this section likely begins in the late middle Smithian (top of Owenites beds) and that the uppermost beds represent the late Smithian Anisibirites zone and the earliest Spathian (Fig. 3B). 

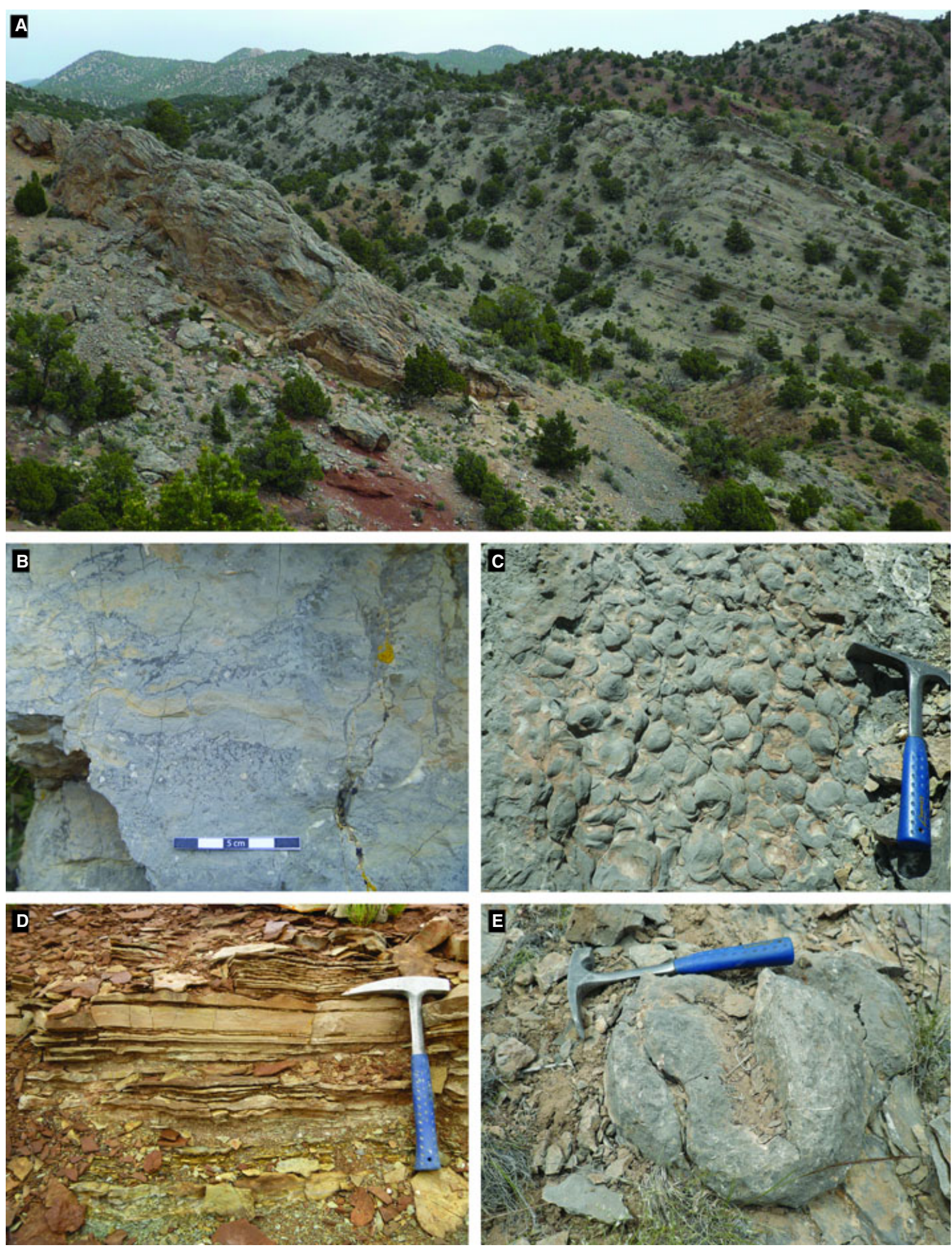

FIG. 7. Field photographs of the Thaynes Formation of the Minersville locality (section MV). A, overview photograph showing the general succession with transitional continental to marine red beds at the base capped by a peritidal microbial complex, which is topped by microbe-sponge bioherms. The largest part of the section is composed of offshore gray marls and limestones. The ridge in the middle part of the picture represents a second level with microbe-sponge build-ups developed in outer shelf settings. The far right shows the red beds of the Moenkopi Formation. B, peritidal limestone with bird's-eye structures. C, mass accumulations of Eumorphotis around the Smithian-Spathian transition. D, ripple cross-bedded sandstones of the Moenkopi Formation intercalated with red siltstones. E, small microbe-sponge build-ups of the Spathian sponge level. Hammer for scale represents $35 \mathrm{~cm}$. 

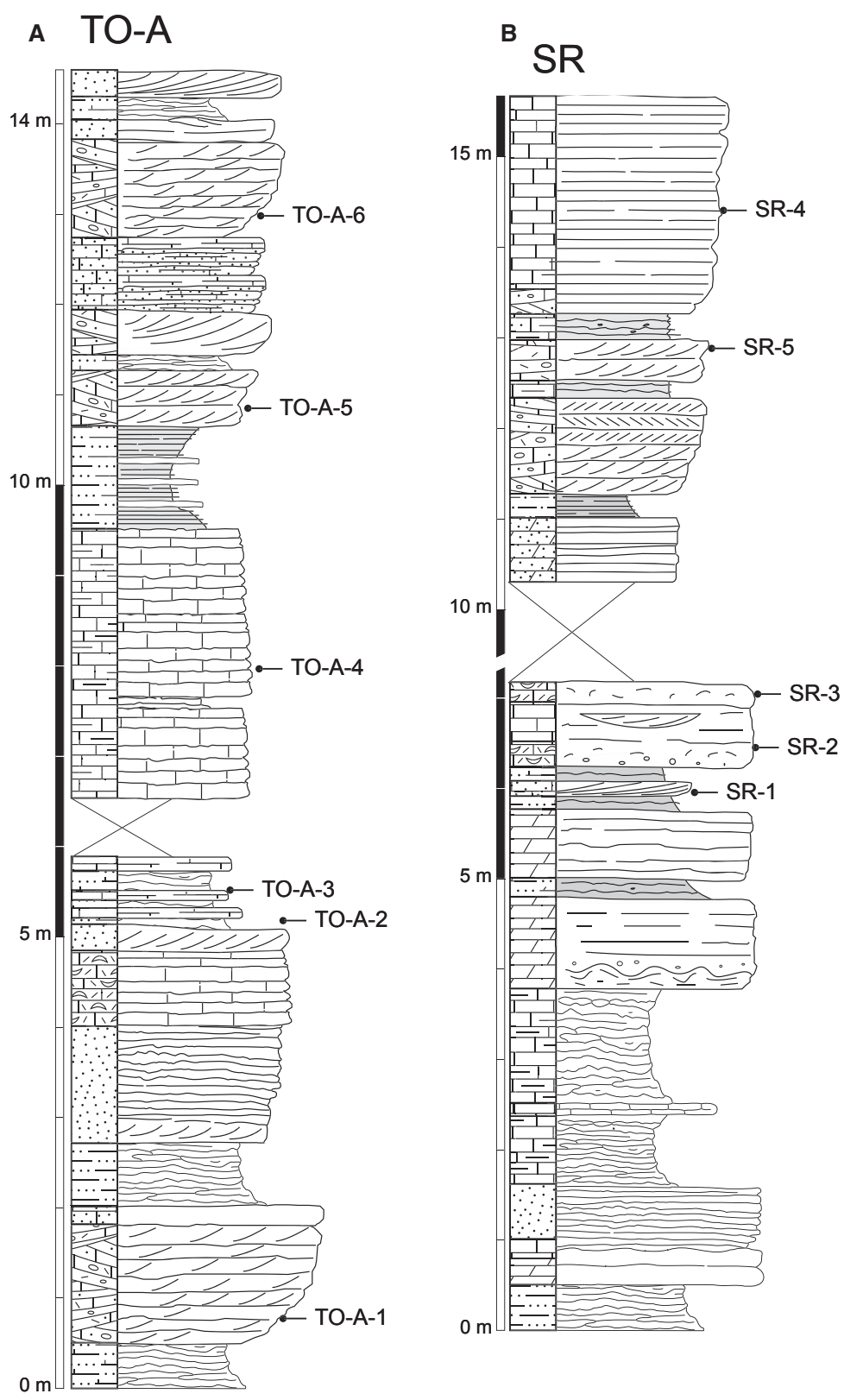

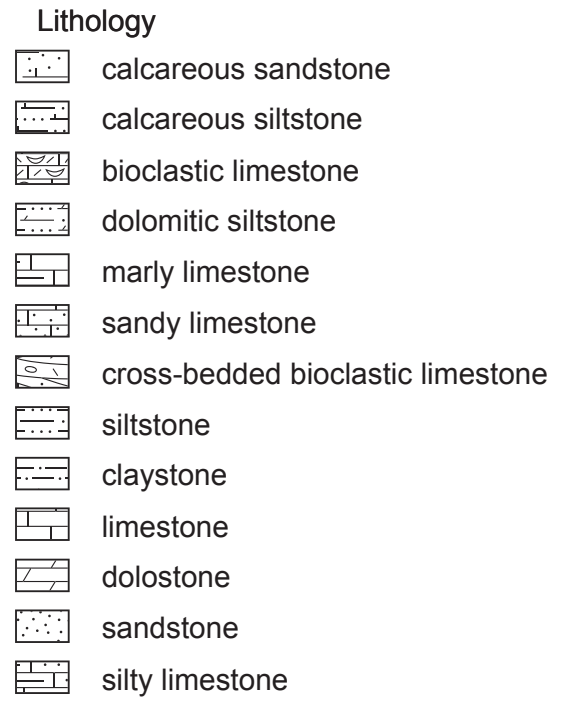

\section{Bedding}

$\triangle$ cross

ripple cross

Earallel

wavy

$\therefore$ stromatolitic lamination

.7. graded tempestite

FIG. 8. Sections of the Sinbad Formation. A, Torrey. B, San Rafael Swell.

\section{Torrey area}

In the area south of Torrey, the Sinbad Formation attains a thickness of about $30 \mathrm{~m}$. Due to the inaccessibility of the lower part of the Formation, we focussed only on the upper $15 \mathrm{~m}$ (Fig. 8A), which corresponds to the middle Smithian Owenites beds and the upper Smithian Anasibirites beds (Fig. 3B). These mixed carbonate-siliciclastic deposits are characterized by crossbedding and tempestitic layers and are thus suggestive of inner and mid-shelf environments. Most samples were derived from intercalated, more fine-grained beds that were deposited between fair weather wave base and storm wave base.

\section{SYSTEMATIC PALAEONTOLOGY}

This published work and the nomenclatural act it contains, have been registered in Zoobank: http://zoobank. org/urn:lsid:zoobank.org:pub:533AF636-F96A-44C9-8E4F8EE6FCFDF768

Benthic fossils from Lower Triassic rocks are notorious for their poor preservation (Schubert and Bottjer 1995; 

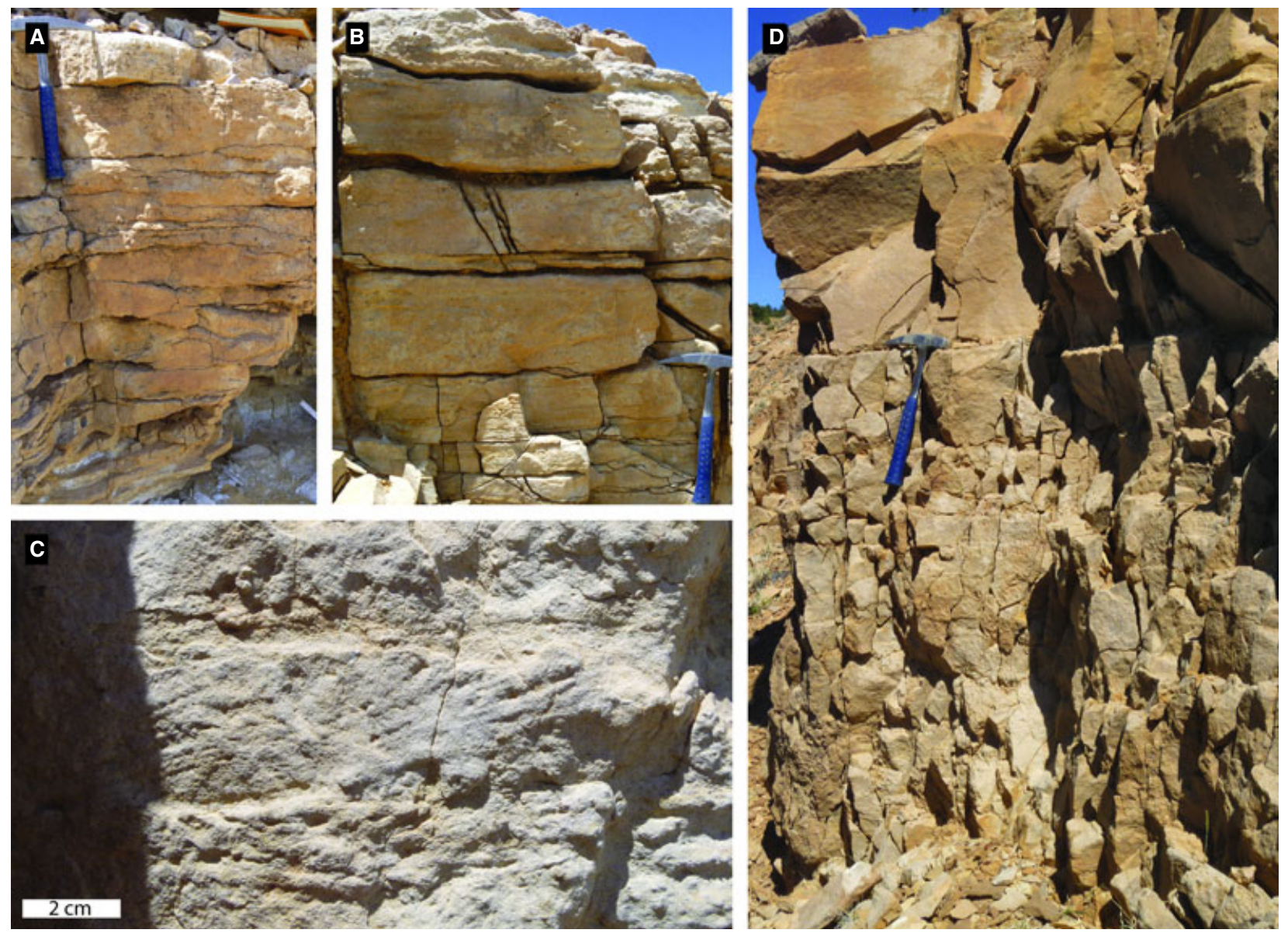

FIG. 9. Field photographs of the Sinbad Formation (San Rafael Swell, section SR: A-C, Torrey, section TO: D). Hammer for scale represents $35 \mathrm{~cm}$. A, medium-bedded bioclastic grainstone of the inner shelf environment. B, medium- to thick-bedded grainstones intercalated with fine-grained intervals indicative of the outer and mid-shelf environment. C, cross-bedded limestones of the inner shelf environment. D, indistinct trough cross-bedded sandy limestone at the base of the section TO.

Hautmann and Nützel 2005). This also applies to much of the material described in this study, which is mainly preserved as internal and external moulds. An in-depth review of the systematic relationship is, thus, hardly possible with the material at hand, but we aimed for specieslevel identification whenever possible. Recent systematic studies of Early Triassic bivalves (Newell and Boyd 1995; Kumagae and Nakazawa 2009; Hautmann et al. 2011, 2013; Wasmer et al. 2012) were used as a taxonomic framework for the palaeoecological analysis.

Gastropod identification is essentially based on the study of Batten and Stokes (1986), which is the only monographic synopsis of the Sinbad Gastropod fauna, and it covers all gastropod species recognized herein. However, supraspecific assignation of many Early Triassic gastropods remains problematic. A revision of taxa described from the Sinbad Formation is currently being carried out by AN. All specimens are housed in collection of Palaeontological Institute and Museum at the University of Zürich (PIMUZ).
Bivalves

by Richard Hofmann and Michael Hautman.

Class BIVALVIA Linnaeus, 1758

Subclass AUTOLAMELLIBRANCHIATA Grobben, 1894 Superorder PTERIOMORPHIA Beurlen, 1944

Order MYTILOIDA de Férussac, 1822

Superfamily MYTILOIDEA Rafinesque, 1815 Family MYSIDIELLIDA Cox, 1964

Genus PROMYSIDIEALLA Waller, 2005

Promysidiella sp $A$.

Figure $10 A-D$

Material. This species is extraordinarily abundant in all samples from the SR section samples TO-A-1 and TO-A-6. It is furthermore recorded in samples DH-1-9, MV-7, CP-101 and TO-A-2. 
558 PALAEONTOLOGY, VOLUME 57
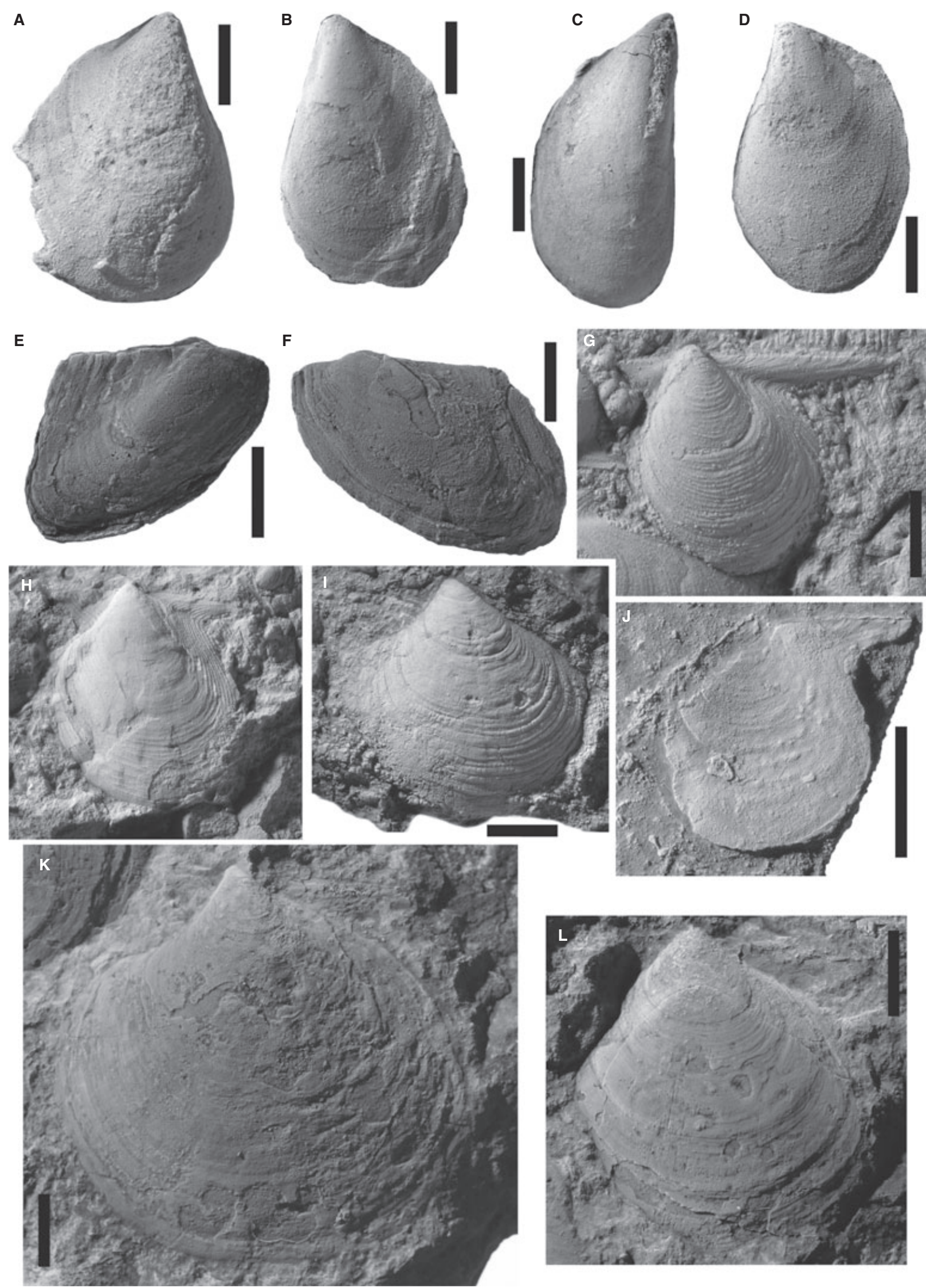
The description is based on numerous specimens from sample SR-4.

Description. Shell equivalved or slightly inequivalved in cases with right valve being less well inflated. Retrocrescent, notably higher than long, well inflated and variable in form ranging from slender mytiliform to broader isognomoniform shapes. Anterior margin straight or slightly concave. Posterio-dorsal margin rounded. Beak narrow and terminal to slightly projecting. Surface smooth except for irregular growth lines. Internal features not observed.

Discussion. Given the high morphological variability, we evaluated the possibility that our material represents two distinct species. However, our survey of 30 left and 31 right valves with regard to equivalved/inequivalved condition, shape of the anterior margin, inclination and shape of the posterior auricle and inflation did not allow morphologically separate populations to be distinguished. All observable morphological characters correspond to the diagnosis of Promysidiella Waller, 2005 (in Waller and Stanley 2005). Another probably related species could be Myalinella postcarbonica, which is described from the Griesbachian-Dienerian Dinwoody Formation (Girty 1927; Hautmann et al. 2011; Hofmann et al. 2013a). Some specimens (e.g. Fig. 10C) of our new collection show close affinities to the material of Girty (1927). However, all specimens observed in the Dinwoody Formation (Hofmann et al. 2013a) have a straight or convex anterior margin. Respective specimens of the Thaynes Group and the Sinbad Formation have a slightly concave anterior margin. Another possible character that is unique to Promysidiella is its clearly projecting beak.

Ecology. The equivalved or near-equivalved condition in combination with a straight anterior margin suggests that this species rested byssally attached with its anterior margin on the substrate. Specimens with a somewhat flattened right valve might have lived in a pleurothetically resting position (Stanley 1972). Regardless of its life position, this species was an epifaunal suspension feeder.

Order PTERIOIDA Newell, 1965

Suborder PTERIINA Newell, 1965

Superfamily PTERIOIDEA Gray, 1847

Family BAKEVELLIIDAE King, 1850

\section{Genus BAKEVELLIA King, 1848 \\ Figure 10E-F}

Bakevellia cf. exporrecta (Lepsius, 1878)

cf. 1878 Gervillia exporrecta Lepsius; p. 352, pl. 1, fig. 6a-c.

1908 Gervillia exporrecta Lepsius; von Wittenburg, p. 279, pl. 4, fig. 10.

1985 Bakevellia exporrecta (Lepsius), Neri and Posenato, p. 92, pl. 1, figs 6, 7 .

2013 Bakevellia cf. exporrecta (Lepsius); Hautmann et al., p. 270, fig. 5I-Q.

Material. This species rarely occurs in the SR, TO and MV sections. It is, however, abundant in sections $\mathrm{DH}-3$ and $\mathrm{CP}$. The description is based on numerous well and completely preserved specimens from bed DH-3-2.

Description. Shell slightly twisted, inequivalve, with left valve being more convex than right valve. Outline of valves trapeziform. Byssal gape not observed. Umbo prosogyrate and located on anterior 30 per cent of the dorsal margin. Beak of left valve slightly projecting above straight hinge line. Shell of both valves covered with fine commarginal growth lines. Internal features not observed.

Discussion. The material described by Hautmann et al. (2013) is conspecific with the material considered in this study. As pointed out in Hautmann et al. (2013), general features agree well with the material figured by Lepsius (1878), but the presence of commissure twisting, which may be relevant in diagnosing species of Bakevellia, cannot be inferred from the figured type material. Accordingly, definite species identification is avoided herein as long as the type material has not been critically examined.

Ecology. This species was a filter feeder that pleurothetically rested on the left valve sunken in the substrate (Hautmann et al. 2013).

$$
\begin{gathered}
\text { Superfamily PTERIACEA Gray, } 1847 \\
\text { Family PTERIIDAE Gray, } 1847
\end{gathered}
$$

Genus CONFUSIONELLA gen. nov.

LSID. urn:lsid:zoobank.org:act:FC20DFE6-D302-4818-B90A6513994AA5C9

FIG. 10. A-D, Promysidiella sp. A from sample SR-4, scale bars represent $3 \mathrm{~mm}$ if not otherwise indicated. A, right valve, PIMUZ 30689. B, left valve, PIMUZ 30687. C, right valve, sample SR-2, scale bar represents $5 \mathrm{~mm}$, PIMUZ 30688. D, left valve, PIMUZ 30690. E-F, Bakevellia exporrecta, sample DH-3-2, all scale bars represent $5 \mathrm{~mm}$. E, right valve, PIMUZ 30692. F, left valve, PIMUZ 30691. G-L, Confusionella loczyi, all scale bars represent $5 \mathrm{~mm}$ if not otherwise indicated. G, left valve, sample DH-1-0, PIMUZ 30686, scale bar represents $3 \mathrm{~mm}$. H, left valve, sample DH-1-5, PIMUZ 30685. I, left valve, sample DH-1-5, PIMUZ 30682. J, right valve, sample DH-1-gs1, PIMUZ 30681. K, left valve, sample DH-2-B, PIMUZ 30683. L, left valve, sample DH-2-B, PIMUZ 30684. 
Type species. Pecten loczyi Bittner, $1901 b$.

Other species. Pseudomonotis laczkoi Bittner, $1901 \mathrm{~b}$.

Derivation of name. Referring to the occurrence in the Confusion Range and the fact that it has been presumably confused with other genera (see discussion).

Diagnosis. Pteriid with suborbicular disc and variable obliquity ranging from infracrescent to retrocrescent. Anterior auricle small, triangular, differentiated from disc by auricular sinus; posterior wing well developed, narrow, distally extending far beyond posterior end of disc.

Remarks. The external shell features and the morphology of anterior auricle and posterior wing in particular are highly suggestive for Pteriidae (see diagnosis in Cox et al. 1969). However, because the ligament system is unknown, there remains the remote possibility that the new taxon may alternatively belong to Pterineidae. However, this family is chiefly Palaeozoic, and no Early Triassic representatives are known. Although several older works figured material that clearly shows the generic characters described above (see synonymy below), the taxonomic affinity of these specimens has not been correctly recognized. They were commonly assigned to Pecten, Pseudomonotis or Aviculopecten, which at that time were understood in a much broader sense than today. With the possible exception of Kumagae and Nakazawa (2009), similar forms have not been reported in more recent studies on Early Triassic bivalves. The excellently preserved material of the Confusion Range gives a hint on the possible cause; the long posterior wing-like projection, which is suggestive of Pteriidae, is prone to mechanical destruction during even short transportation or moderate wave action. If this feature is absent, which is the case in many specimens observed herein (e.g. Fig. $10 \mathrm{H}-\mathrm{I}$ ), the almost equilateral disc resembles entoliids, which are quite abundant in Lower Triassic rocks (see synonymy for examples of possible misidentifications such as Scythentolium or Entolioides).

\section{Confusionella loczyi (Bittner, 1901b)} Figure 10G-L

*1901 Pecten lóczyi, Bittner, p. 89, pl. 9, figs 28-32 (non fig. 30).

1907 Pseudomonotis Lóczyi (Bittner); Frech, p. 22, pl. 6, fig. 6.

1908 Pecten sojalis n. sp., von Wittenburg, p. 21, pl. 1, fig. 6 non 9.
? 1927 Aviculipecten disjunctus n. sp., Girty, p. 437, pl. 30, figs 22-24.

? 1938 Pecten (Chlamys) kryshtofowichi n. sp., Kiparisova, p. 291, pl. 5, figs 7-10.

1972 Scythentolium sojale Wittenburg, Allasinaz, p. 311, pl. 41 , fig. 8 .

? 2004 Entolium ussuricus Bittner, Kashiyama and Oji, p. 213 , fig. 8 d, e.

2009 Entolium sp. indet., Kumagae and Nakazawa, p. 165 , fig. 144.14 .

Revised diagnosis. Confusionella with very regular, fine but distinct commarginal ribs. Radial ornament absent.

Material. Frequently recorded in all samples DH-1-0 to DH-1-9. The description is based on well-preserved specimens (PIMUZ 30686, 30685, 30682, 30681, 30683, 30684).

Description. Shell slightly inequivalve, with left valve being more convex than right valve. Disc suborbicular to ovate with apical angle of $c .85$ degrees. Shell infracrescent to retrocrescent. Hinge margin straight, with orthogyrous to prosogyrous umbo projecting above hinge line. Umbo located on anterior 30 per cent of dorsal margin. Anterior auricle triangular, with well-developed auricular sinus. Posterior wing narrow and strongly elongated. Disc and auricles covered with regular, closely spaced, very fine, but distinct commarginal ribs.

Discussion. A probably closely related species is what Bittner introduced as Pseudomonitis laczkoi, which is very similar with respect to the general shape and configuration of the auricles. It differs from C. loczyi in showing a distinct radial ornament (see also Frech 1907). It is very likely that Pseudomonitis laczkoi pertains to the genus Confusionella as well.

The very conspicuous regular commarginal sculpture and the discoid shape can easily be recognized in hitherto-described material from the western USA (Girty 1927) and Ussuri Bay (Kiparisova 1938; Kumagae and Nakazawa 2009). Having studied the material from the Confusion Range, some 'entoliid' bivalves (Allasinaz 1972; Kashiyama and Oji 2004; Kumagae and Nakazawa 2009) described in the literature may also belong to Confusionella. If our assignation is correct, this genus would be very common in Smithian strata such as the Hidegkut Sandstone of the Balaton Region (Bittner 1901b), the Campil Member of the Dolomites (Wittenburg 1908; Allasinaz 1972) and the Thaynes Group (Girty 1927; this paper).

Ecology. The flat right valve and shallow byssal sinus suggest that Confusionella was a byssally attached epifaunal suspension feeder. 


\section{Order PECTINOIDA Gray, 1854 \\ Suborder PECTININA Waller, 1978 \\ Superfamily AVICULOPECTINOIDEA Meek and Hayden, 1864 Family ASOELLIDAE Begg and Campbell, 1985}

Genus LEPTOCHONDRIA Bittner, 1891

Leptochondria occidanea (Meek, 1877) Figure $11 \mathrm{~A}-\mathrm{C}$

\footnotetext{
${ }^{\star} 1877$ Aviculopecten occidaneus Meek, p. 96, pl. 12, fig. 13a, b.

1909 Pecten viezzensis, Wilckens, p. 147, pl. 5, fig. 25.

1927 Monotis superstricta var. parksi, Girty, 1927, p. 441, pl. 30, figs 20, 21.

1972 Leptochondria viezzensis (Wilckens), Allasinaz, p. 259, pl. 31, figs 5-9.

1995 Leptochondria occidaneus (Meek), Newell and Boyd, p. 70, fig. 51.3-51.9.

2012 Leptochondria viezzensis (Wilckens), Wasmer and Hautmann, p. 1058, fig. 7K-R.
}

Material. Present in all samples of the Disappointment Hills sections except DH-1-gs2, DH-1-5 and DH-1-5. Particularly abundant in sample DH-1-3. Present in DV-5 of the Dog Valley section. The description is based on abundant well-preserved specimens from section DH-1 and sample CP-8.

Description. Disc almost equilateral, orbicular, slightly higher than long. Left valve feebly convex with orthogyrate umbo slightly projecting above straight dorsal margin. Umbo located at anterior 40 per cent of hinge line. Anterior auricle well demarcated from disc, with shallow auricular sinus. Posterior auricle not preserved. Valves covered with up to 45 simple radial ribs, rounded in shape. Few second-order ribs distally inserted by intercalation. Radial ornamentation fading out towards anterior and posterior margin including both auricles. Very weak and dense commarginal riblets present on the entire valve. Internal features unknown. Right valve not observed.

Discussion. The specimens from the Thaynes Group and Sinbad Formation agree well with $L$. occidanea figured in Newell and Boyd (1995), including a relatively pronounced anterior auricular sinus, a large posterior auricle and second-order ribs inserted by intercalation. In terms of ornamentation, Leptochondria viezzenensis is virtually indistinguishable from L. occidanea, but it has been suggested (Wasmer et al. 2012) that the sinuate posterior left auricle is a diagnostic feature of L. viezzenensis. However, published material, which has subsequently been assigned to L. occidanea (e.g. M. superstricta var. parksi Girty 1927), shows the same morphology, which is also the case for material described herein (Fig. 11C). Accordingly, we suggest $L$. viezzenensis is a junior synonym of L. occida- nea. As pointed out by Wasmer et al. (2012), Leptochondria bittneri (Kiparisova, 1938) lacks a sinuate posterior auricle, but is otherwise very similar to L. occidanea. Leptochondria occidanea is very common in the Early Triassic of the western USA, especially throughout the Smithian and Spathian time interval (Newell and Boyd 1995).

Ecology. The genus has a flat right valve with byssal notch (not observed in the present material), which suggests that Leptochondria was a byssally attached epifaunal filter feeder resting pleurothetically on the right valve.

\section{Leptochondria xijinwulanensis Sha 1995 Figure 11D-E}

\footnotetext{
*1995 ?Leptochondria xijinwulanensis sp. Sha, p. 94, pl. 26, figs $1-6$.

1995 Leptochondria cf. albertii (Goldfuss); Sha, p. 92, pl. 26, fig. 7.

1995 Leptochondria albertii (Goldfuss); Sha, p. 92, pl. 26, fig. 9.

1995 Leptochondria sp., Sha, 94, pl. 26, fig. 24.

1996 ?Leptochondria xijinwulanensis (Sha, 1995); Sha and Grant-Mackie, pl. 3, fig. j.

2012 Leptochondria xijinwulanensis (Sha, 1995); Wasmer and Hautmann, p. 1058, fig. 7D-J.
}

Material. Two left valves DH-1-5 and one left valve in DH-1-9. The description is based on the figured specimens PIMUZ 30676 and PIMUZ 30680).

Description. Left valve subcircular, convex, nearly equilateral and slightly higher than long. Auricles subequal in size, obtuse and well demarcated from the disc. Anterior auricle subtriangular. Posterior auricle with shallow sinus. Beak not projecting above straight dorsal margin. Umbo orthogyrate to slightly prosogyrate, located near the midst of dorsal margin. Internal features unknown. Left valve covered with up to 30 simple, relatively widely spaced sharp radial ribs. Second-order ribs are distally inserted by intercalation. Very weak, commarginal riblets present, most notably developed on posterior and anterior side of disc. Right valve and shell interior not observed.

Discussion. The specimens from the Confusion Range agree very well with features of L. xijinwulanensis Sha, 1995 from the Early Triassic of western China. Most notably, the characteristic ornamentation with comparably few widely spaced and pronounced radial ribs is virtually indistinguishable from the material figured by Sha (1995) and Sha and Grant-Mackie (1996). Wasmer et al. (2012) reported the same species from the Spathian of Pakistan and noted a variety of morphological 

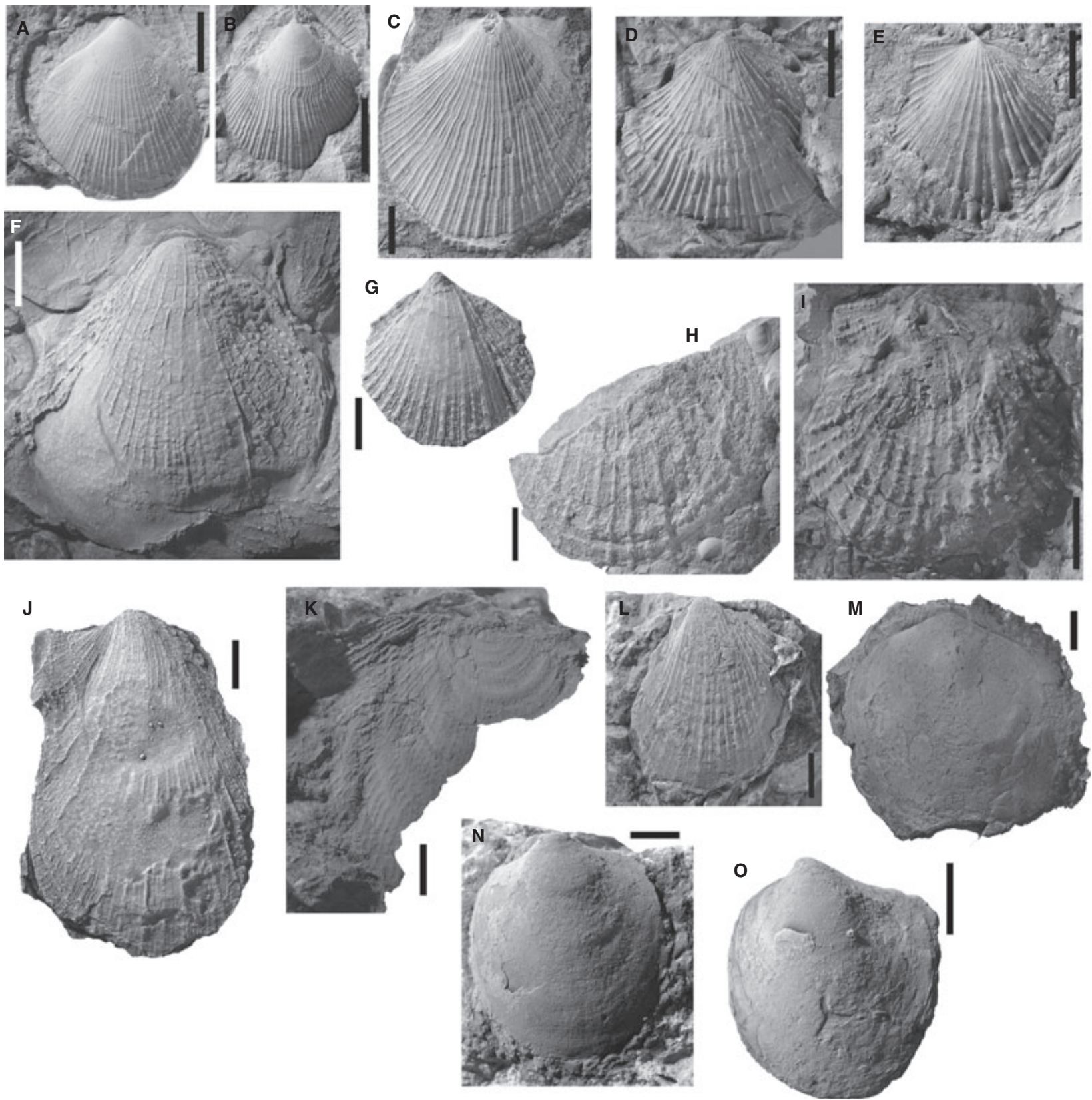

FIG. 11. A-C, Leptochondria occidanea, all scale bars represent $5 \mathrm{~mm}$. A, left valve, sample DH-1-4, PIMUZ 30677. B, left valve, sample DH-1-4, PIMUZ 30678. C, left valve, sample CP-8, PIMUZ 30679. D-E, Leptochondria xijinwulanensis. D, left valve, sample DH-1-5, PIMUZ 30676, scale bar represents 5 mm. E, left valve, sample DH-1-9, PIMUZ 30680, scale bar represents 3 mm. F, Eumorphotis ericius, left valve, float at the top of section DH-3, PIMUZ 30667, scale bar represents $10 \mathrm{~mm}$. G-H, Eumorphotis beneckei. G, left valve, sample DH-2-B, PIMUZ 30668, scale bar represents $5 \mathrm{~mm}$. H, fragment of a left valve, sample DH-1-2, PIMUZ 30669, scale bar represents $10 \mathrm{~mm}$. I, Eumorphotis hinnitidea, left valve, sample CP-4, PIMUZ 30666, scale bar represents $10 \mathrm{~mm}$. J-L, Eumorphotis multiformis, all scale bars represent $5 \mathrm{~mm}$. J, left valve, sample DV-2, PIMUZ 30671. K, right valve, sample DH-3-1, PIMUZ 30670. L, left valve, sample MV-10, PIMUZ 30672. M, Pernopecten? sp. A, right valve, sample TO-A-5, PIMUZ 30673, scale bar represents $10 \mathrm{~mm}$. N-O, Crittendenia? sp. A, all scale bars represent 5 mm. N, left valve, sample SR-3, PIMUZ 30674. O, left valve, DH-2 B, PIMUZ 30675.

features, which further lends support to the species identification of the material presented herein. Sha (1995) figured some specimens of Leptochondria, which he assigned to L. cf. albertii (pl. 26, fig. 7), L. albertii (pl. 26, fig. 9) and L. sp. (pl. 26, fig. 24). We note that all of these specimens closely resemble the type material 
of L. xijinwulanensis in having widely spaced and sharp radial ribs on the shell exterior, which is not found in any other species of Leptochondria (Wasmer et al. 2012). A possible criterion for separating these forms on the species level could be the presence of commarginal riblets in 'L. albertii' and ' $L$. sp' in Sha (1995). However, our material and that described by Wasmer et al. (2012) suggests that this feature is very variable among specimens that are otherwise indistinguishable. This indicates that the development of commarginal ribs or riblets may rather reflect taphonomic and diagnetic effects as well as potential intraspecific variation and, thus, could not be considered as diagnostic criterion for species differentiation. We follow Wasmer et al. (2012) and unite all Leptochondria with this type of ornamentation under L. xijinwulanensis.

Ecology. As for L. occidanea.

Family HETEROPECTINIDAE Beurlen, 1954

Genus EUMORPHOTIS Bittner, 1901a

*1901 Eumorphotis, Bittner, p. 56.

1983 Neomorphotis, Yin and Yin. [In Chinese].

2009 Neomorphotis Fang et al., p. 34. [English translation of original diagnosis].

Discussion. Eumorphotis was erected by Bittner (1901a) to accommodate species of aviculopectinids with well-developed auricles and a flat right valve that were previously placed in Pecten or Pseudomonotis. Neomorphotis Yin and Yin, 1983 agrees well with all typical features of Eumorphotis except for its notably large size and Spondylus-like ornamentation (Fang et al. 2009). However, size is generally a poor criterion for distinguishing between taxa. Furthermore, Bittner (1901a) had already pointed out that Eumorphotis shows a great variability and intergradational stages regarding its ornamentation, including what has been suggested as diagnostic for Neomorphotis. Accordingly, we consider Neomorphotis a junior synonym of Eumorphotis.

Eumorphotis beneckei (Bittner, 1901a) Figure $11 \mathrm{G}-\mathrm{H}$

*1901 Pseudomonotis beneckei, Bittner, p. 574, pl. 23, fig. 5.

1986 Eumorphotis beneckei (Bitter, 1901) Broglio Loriga and Mirabella, p. 271, pl. 3, figs 3-6.

2008 Neomorphotis compta (Goldfuss, 1838) Posenato, p. 101, fig. $4 \mathrm{~A}-\mathrm{G}$.
Material. Two left valves in sample DH-2-B and one left valve in sample DH-1-5. The description is based on two specimens (PIMUZ 30668, 30669).

Description. Left valve moderately inflated, presumably retrocrescent. Umbo orthogyrate and projecting above hingeline. Auricles not preserved. Radial ornamentation with about 15 strong nodular first-order ribs. A set of numerous (up to seven) fine second-order ribs between each two-first-order ribs. Right valve and internal features not observed.

Discussion. Eumorphotis beneckei is distinguished from all other described species of Eumorphotis with strong squamose radial ribs (see discussion of Eumorphotis ericius and Eumorphotis hinnitidea) by numerous delicate second-order ribs. The type specimen has been described from the Anisian of the Dolomites (Bittner 1901a). Posenato (2008) placed E. beneckei in synonymy with Ostrea compta Goldfuss, 1838, based on the striking similarity in ornamentation. However, the original specimen figured by Goldfuss (1838) shows few diagnostic characters in addition to ornamentation, which gave rise to much confusion about the proper definition of this species, summarized in Posenato (2008) and Hautmann and Hagdorn (2013). We therefore prefer to regard Ostrea compta as a nomen dubium and include our material as the well-defined E. beneckei.

Ecology. The flat right valve and the byssal sinus in the left anterior auricle suggest that E. beneckei was epibyssally attached resting on its flat right valve.

Eumorphotis ericius Hautmann et al., 2013 Figure $11 \mathrm{~F}$

?1908 Pseudomonotis beneckei Bittner, von Wittenburg, p. 29, pl. 4, fig. 1.

?1908 Pseudomonotis reticulatus Richthofen; von Wittenburg, p. 30, pl. 2, figs 8,9 .

*2013 Eumorphotis ericius n. sp. Hautmann et al., p. 275, fig. $6 \mathrm{H}-\mathrm{L}$.

Material. Frequently observed in beds around Smithian-Spathian boundary interval. The description is based on several wellpreserved specimens from samples CP-3 and CP-5.

Description. Large, well-inflated left valve, higher than long, usually infracrescent, slightly retrocrescent in early growth stages. Umbo slightly prosogyrate, near mid-point of straight dorsal margin. Anterior auricles with shallow auricular sinus, posterior auricles wide. Radial sculpture well developed, with numerous (up to 70) squamose first-order ribs and weaker second-order ribs inserted by intercalation. Ribs of third order rarely observed. Internal features and right valves not observed. 
Discussion. This species is easily recognized by its numerous squamose ribs. It has been described from the lower Spathian Virgin Formation of the western USA (Hautmann et al. 2013) and is abundant in coeval rocks of the Thaynes Group of the investigated area. It occurs in high abundances in the Confusion Range and at the Mineral Mountains section and forms paucispecific bedding-plane assemblages within the basalmost Spathian. This species is also a typical constituent of diverse benthic inner shelf assemblages of the Virgin Formation (Hofmann et al. 2013b). It has also been tentatively described from the Griesbachian to Dienerian Dinwoody Formation of Montana (Hofmann et al. 2013a). In the Werfen Formation of the Dolomites, it may be represented by 'Pseudomonotis beneckei' of Wittenburg (1908, pl. 4, fig. 1) that closely resembles the type material from the Virgin Formation (Hautmann et al. 2013) in general shape and the characteristic sculpture. Another specimen described as P. reticulatus by Wittenburg (1908, pl. 2, figs 8, 9) is also very similar to E. ericius. However, the type specimen of Eumorphotis reticulata (= Spondylus reticulatus Richthofen, 1860) has never been figured. The description by Richthofen (1860) that has been cited by Wittenburg (1908) does not match completely the Wittenburg material. For instance, the figured specimen of $P$. reticulatus is neither obliquely oval nor does it possess three to four secondary ribs between the primary ribs towards the margin (Richthofen 1860). Accordingly, the affinity of Wittenburg's P. reticulatus and, hence, the relationship of E. ericius with Eumorphotis reticulatus (Richthofen, 1860) remain unclear without an examination of the type material of the Richthofen (1860) material.

Ecology. As for E. beneckei.

Eumorphotis hinnitidea (Bittner, 1898) Figure 111

${ }^{\star} 1898$ Pseudomonotis hinnitidea Bittner, p. 716, pl. 15, figs $8-10$.

1908 Pseudomonotis spinicosta von Wittenburg, p. 76, figs 6, 7.

1986 Eumorphotis hinnitidea (Bittner), Broglio Loriga and Mirabella, p. 266, pl. 4, figs 1-3.

Material. One left valve from sample CP-4.

Description. Relatively large, feebly inflated left valve, subcircular in outline and slightly procrescent. Umbo orthogyrate, located in the midst of straight dorsal margin. Anterior auricle with shallow sinus. Posterior auricle obtuse. One order of about 25 strong spinose radial ribs. Faint commarginal riblets forming a reticulate pattern by intersection with the radial ribs.

Discussion. This species is characterized by its circular outline and comparably few, robust, squamose radial ribs. We follow the revision of Broglio Loriga and Mirabella (1986) who suggested that Eumorphotis spinicosta is a junior synonym of E. hinnitidea. The similar species E. ericius is notably higher than long and has more ribs intercalated in two ranks. This is the first report of E. hinnitidea from Panthalassa, where it is confined to the lowermost Spathian. In the Tethys, this species has been observed in Smithian and Spathian strata Broglio Loriga and Mirabella (1986).

Ecology. As for E. beneckei.

Eumorphotis multiformis (Bittner, 1899)

Figure $11 \mathrm{~J}-\mathrm{L}$

${ }^{\star} 1899$ Pseudomonotis multiformis; Bittner, p. 10, p1. 2, figs 15-22.

1942 Eumorphotis multiformis (Bittner, 1899); Newell and Kummel, p. 957, p1. 2, figs 10, 11.

1963 Eumorphotis multiformis (Bittner, 1899); Ciriacks, p. 77, pl. 15, figs 13, 15.

1963 Eumorphotis multiformis regularaecosta Kiparisova; Ciriacks, 1963, p. 77, pl. 15, fig. 14.

2009 Eumorphotis multiformis (Bittner, 1899); Kumagae and Nakazawa, p. 162, fig. 144.17 (cum synonymis).

Material. Rather rare in samples DV-2, DH-3-1, DH-3-3, SR-1, MV-3, MV-5, MV-6 and MV-10. The description is based on several well-preserved specimens from DV-2, DH-3-1.

Description. Left valve weakly to moderately inflated, almost equilateral, infracrescent. Umbo orthogyrate to slightly prosogyrate, slightly projecting above straight hinge line and placed centrally. Anterior auricle well demarcated from disc, with shallow auricular sinus. Posterior auricle not observed. Left valve covered with three orders of radial ribs being irregularly intercalated.

Discussion. Eumorphotis multiformis is characterized by multiple orders of intercalated, mostly smooth radial ribs in variable configurations. However, no clear distinction of discrete morphotypes has been established so far. Earlier workers introduced a number of varieties or subspecies of E. multiformis (see Broglio Loriga and Mirabella (1986) for overview), but more recent taxonomic practice (Kumagae and Nakazawa 2009) considers the various subspecies of E. multiformis as synonyms of a highly variable species. Eumorphotis multiformis has a cosmopolitan distribution and is reported from the Griesbachian 
(Ciriacks 1963), Dienerian (Broglio Loriga and Mirabella 1986) and the Spathian (Hautmann et al. 2013).

Ecology. As for E. beneckei.

Family DELTOPECTINIDAE Dickins, 1957

Genus CRITTENDENIA Newell and Boyd, 1995

Crittendenia? sp.

Figure $11 \mathrm{~N}-\mathrm{O}$

Material. Rarely recorded in samples DH-2B, DV-3, SR-1, SR-2, SR-3. The description is chiefly based on some well-preserved left valves from sample SR-3.

Description. Left valve suborbicular to slightly retrocrescent, slightly higher than long and distinctly inflated. Umbo prominent, prosogyrous, with beak projecting well beyond hinge line. Posterior auricle poorly differentiated from disc. Valves generally smooth except for very faint commarginal growth lines. Right valve not observed.

Discussion. Newell and Boyd (1995) introduced the genus Crittendenia to accommodate species of the Claraia decidens group of Ichikawa (1958), which are characterized by a well-inflated left valve and absent or very weak ornamentation. Crittendenia, as defined by Newell and Boyd (1995), applies to species with an almost flat right valve, as exemplified by the type species Crittendenia kummeli. Newell and Boyd also included material from the Salt Range in this species, which however has recently been placed in Eobuchia punjabensis (Wasmer et al. 2012). The left valve of Crittendenia is virtually indistinguishable from that of Eobuchia, but its right valve clearly differs in having a strongly prosogyrate umbo and a very wide byssal notch below the anterior auricle (Wasmer et al. 2012). Accordingly, without knowledge on the morphology of the right valve, the material at hand could be assigned to either genus. Because Crittendenia has previously been reported from the Smithian of the Thaynes Group (Newell and Boyd 1995), we provisionally place our material in this genus.

Ecology. Crittendenia was an epifaunal, byssally attached filter feeder (Wasmer et al. 2012).

\section{Suborder ENTOLIIDINA Hautmann, 2011 Superfamily ENTOLIOIDEA Korobkov, 1960 Family ENTOLIIDAE Korobkov, 1960}

Remarks. As noted by Hautmann et al. (2013), splitting the Entoliidae into various families and subfamilies is not justified on the basis of observed morphological differences.

Genus PERNOPECTEN Winchell, 1865

\author{
Pernopecten? sp. A \\ Figure $11 \mathrm{M}$
}

Material. Rarely recorded in samples TO-A-4, TO-A-5 and TOB-5. The description is based on a comparatively well-preserved right valve from sample TO-A-5 (PIMUZ 30673) and poorly preserved left? valves from the same sample.

Description. Shell fairly large, subcircular in outline, orthocline and equilateral. Left valve feebly inflated. Auricles not observed in left valves. Right valve feebly inflated, with small beak not projecting above hinge margin, placed at or near the midst of the straight hinge line. Auricles without scrolls, anterior auricle small, rounded, with very shallow sinus, posterior auricle obtuse and slightly larger than anterior one. Surface of both valves smooth.

Discussion. As noted by Waller (2006), Pernopecten represents the only entoliid genus in which projecting auricles (scrolls in Waller 2006) occur in the left valve and not in the right valve, as is the case in all other entoliids that developed this feature. Entolioides Allasinaz, 1972 lacks scrolls in both valves, but this genus differs in having a well-developed radial ornamentation. Based on the specimens from the Thaynes Group of Nevada, Idaho and Montana, Newell and Boyd (1995) erected Entolioides utahensis, in which the right valve is similar to the material presented herein. Left valves of this species should show a distinct radial sculpture - a trait considered as typical for the genus Entolioides by Allasinaz (1972) and Newell and Boyd (1995, p. 76). We did not observe radial ornamentation of this kind in our material. Although right/left valve determination is uncertain in most cases, we regard it unlikely that left valves are completely lacking in our samples. We therefore tentatively place our material in Pernopecten rather than in Entolioides.

Pernopecten is a chiefly late Palaeozoic genus (Newell 1938), but it also ranges into the Early Triassic (Posenato et al. 2005; Waller 2006; Hautmann et al. 2013). Waller (2006) suggested that Pernopecten gave rise to all younger representatives of the Pectinoidea during the Early Triassic, but this hypothesis was rejected by Hautmann (2010) and Carter and Hautmann (2011) who assumed a diphyletic origin of the entolioid and pectinoid clades.

Ecology. Pernopecten was a free-lying epifaunal filter feeder probably capable of swimming by rapidly clapping its valves (Stanley 1972; Hautmann 2004). 
Subclass HETEROCONCHIA Hertwig, 1895

Superorder PALAEOHETERODONTA Newell, 1965

Order MODIOMORPHOIDA Newell, 1969

Superfamily MODIOMORPHOIDEA Miller, 1877

Family KALENTERIDAE Marwick, 1953

Genus PERMOPHORUS Chavan, 1954

Permophorus cf. bregeri (Girty, 1927)

Figure 12A-D

cf. ${ }^{\star} 1927$ Pleurophorus bregeri n. sp.; Girty, p. 445, pl. 30, figs 40, 41.

cf. 1927 Pleurophorus similis n. sp.; Girty, p. 446, p1. 30, figs $38,39$.

cf. 1927 Pleurophorus rotundus n. sp.; Girty, p. 446, pl. 30, figs $42,43$.

1963 Permophorus? bregeri (Girty); Ciriacks, p. 83, pl 16, figs $8,9$.

Material. Recorded in relatively high numbers in sample SR-4. Description is based on all specimens shown in Fig. 12.

Description. Shell equivalved, subrectangular in outline, considerably longer than high. Umbo almost terminal, strongly prosogyrate, with very small beak slightly projecting above dorsal and anterior margin. Dorsal and ventral margin straight and subparallel. Posterior margin rounded. Anterior margin truncated with small lunule. Straight carina running from the umbo towards the posteroventral corner of shell. Faint radial ridge on the posterio-dorsal part of the valves.

Discussion. We follow Ciriacks (1963) who suggested that all three species of 'Pleurophorus' (P. similis, P. bergeri and $P$. rotundus) represent the species of Permophorus bregeri (see also Hofmann et al. 2013a, for discussion). Given the considerable variability of $P$. bregeri, the material from the Sinbad Formation is best placed within this

A

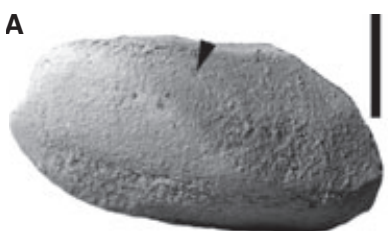

C

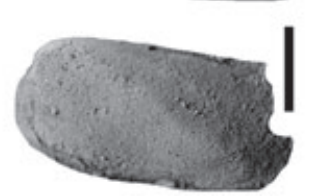

B

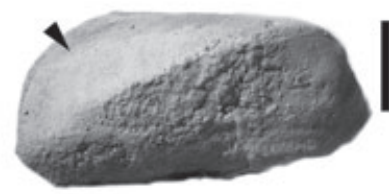

D

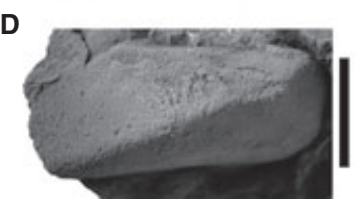

FIG. 12. Permophorus cf. bregeri, all scale bars represent $3 \mathrm{~mm}$. Black arrows point to the faint second diagonal ridge. A, left valve, sample SR-4, PIMUZ 30712. B, right valve, sample SR-4, PIMUZ 30713. C, left valve, sample SR-4, PIMUZ 30714. D, right valve, sample SR-4, PIMUZ 30715.

species. However, it is noted that the diagonal ridge in some specimens is slightly S-shaped (Fig. 12C) and that the specimens from the Sinbad Formation are somewhat more elongated.

We note that the external morphology of this species is very similar to Middle Triassic Protopis Kittl, 1904, provisionally placed in the modiomorphoid family Healeyidae Hautmann, 2008 by Hautmann (2008). Placement of Protopis in Permophoridae appears a possible alternative, depending on the presence or absence of a comparable hinge dentition, which is currently unknown in Protopis.

Ecology. The modioliform shape of $P$. cf. bregeri suggests an endobyssate mode of life (cf. Stanley 1972).

Order UNIONOIDA Stoliczka, 1871

Superfamily ANTHRACOSIOIDEA Amalizky, 1892

Family ANTHRACOSIIDAE Amalizky, 1892

\section{Genus UNIONITES Wissmann, 1841 (in Münster)}

Remarks. We follow the revision of Geyer et al. (2005) that indicates the assignment of Unionites to Anthracosiidae Amalizky, 1892. Most reports of Early Triassic Unionites are based on external morphological characters, which are of limited value in terms of genus identification. Our material is no exception in this respect, and thus, generic assignment to Unionites represents conventional practice rather than new morphological information.

Unionites cf. canalensis (Catullo, 1846)

Figure 13A-B

cf. ${ }^{\star} 1846$ Tellina canalensis; Catullo, p. 56, pl. 4, fig. 4 .

1859 Tellina (Myacites) canalensis Catullo, 1846; Schauroth, p. 327, pl. 2, fig. 17.

1923 Anodontophora canalensis (Catullo, 1846); Diener, p. 230 (cum synonymis).

1963 Unionites canalensis (Catullo, 1846); Ciriacks, p. 81, pl. 16, figs 11, 12 .

2009 Unionites canalensis (Catullo, 1846); Kumagae and Nakazawa, p. 166, fig. 145.1-145.4 (cum synonymis).

Material. Recorded in samples DV-1, DV-2, SR-4 and TO-A-1. Preserved as internal and external moulds. The description is based on relatively well-preserved external moulds from SR-4 (PIMUZ 30700, 30696).

Description. Shell equivalved, outline elongate subelliptical. Ventral margin nearly straight. Umbones prosogyrous, with beak 
projecting above dorsal margin and located approximately in the midst or slightly shifted towards the anterior side of dorsal margin. More or less well-developed umbonal ridge. Posterior margin truncated. Anterior margin rounded. Internal features unknown.

Discussion. Unionites canalensis is a widely reported species from Lower Triassic rocks and is distinguished from the similar Unionites fassaensis by its more elongated outline and more pronounced umbonal ridge (Kumagae and Nakazawa 2009). Ciriacks (1963, p. 82) emphasized a medial location of the umbones in his material of $U$. canalensis, but other descriptions report a position of the umbones in the anterior part of the shell (von Schauroth 1859; Hautmann et al. 2013). In the material at hand, the position of the umbones is variable, but generally anterior to the centre of the dorsal margin (compare figs A and B). Given the lack of diagnostic characters in addition to the general shape, however, the taxon remains poorly defined.

Ecology. Unionites canalensis was a shallow infaunal suspension feeder (Hautmann et al. 2013).

Unionites cf. fassaensis (Wissmann [In Münster]), 1841 Figure 13C-D

cf. ${ }^{\star} 1841$ Myacites fassaensis Wissmann, 1841, p. 9, pl. 16, fig. $2 \mathrm{a}-\mathrm{c}$.

1963 Unionites fassaensis (Wissmann); Ciriacks, p. 82, pl. 16, fig. 13.

?1963 Unionites breviformis (Spath); Ciriacks, p. 81, pl. 16, figs 14,15 .
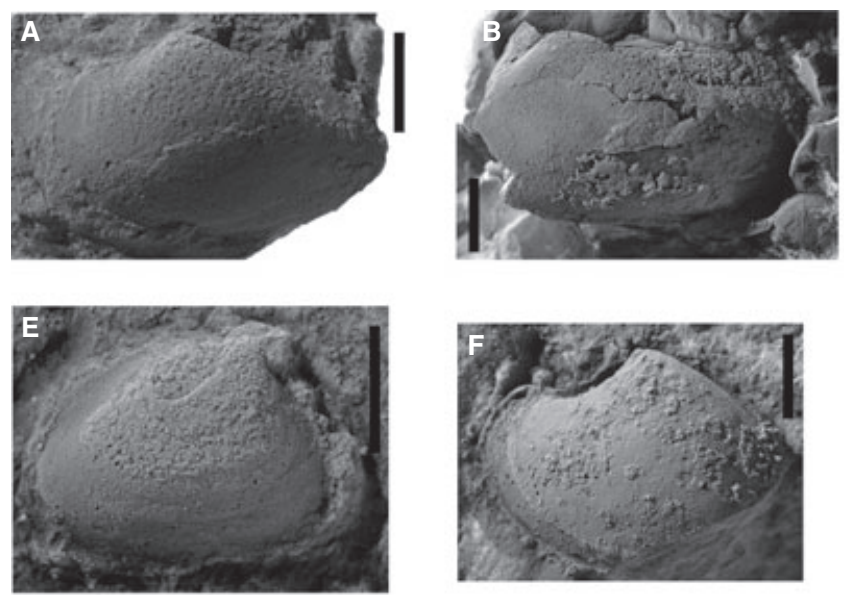

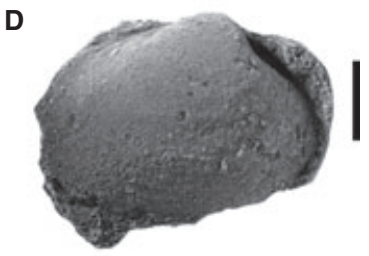

G

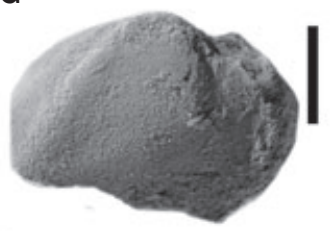

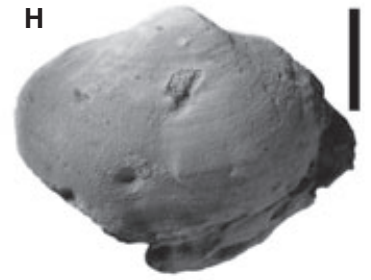

FIG. 13. A-B, Unionites cf. canalensis, all scale bars represent $5 \mathrm{~mm}$. A, left valve, sample SR-4, PIMUZ 30700. B, left valve, sample SR4, PIMUZ 30696. C-D, Unionites cf. fassaensis. C, left valve, sample SR-2, PIMUZ 30699, scale bar represents $5 \mathrm{~mm}$. D, right valve, sample SR-2, PIMUZ 30698, scale bar represents $3 \mathrm{~mm}$. E, Neoschizodus laevigatus, right valve, sample SR-4, PIMUZ 30695, scale bar represents $3 \mathrm{~mm}$. F, Sinbadiella pygmaea, right valve, TO-A-2, PIMUZ 30693, scale bar represents $3 \mathrm{~mm}$. G, Sementiconcha recuperator, right valve, SR-4, PIMUZ 30694, scale bar represents 3 mm. H, Unicardium sp. A, left valve, DH-1-gs2, PIMUZ 30697, scale bar represents 5 mm. 
Neoschizodus laevigatus (Ziethen, 1830)

Figure $13 \mathrm{E}$

${ }^{\star} 1830$ Trigonia laevigata; Ziethen, p. 94, pl. 71, figs 2, 6.

1923 Myophoria laevigata (Ziethen); Diener, p. 174 (cum synonymis).

1963 Myophoria laevigata (Ziethen, 1830); Ciriacks, p. 82 , pl. 18, figs 18,19 .

2009 Neoschizodus cf. laevigatus (Ziethen); Kumagae and Nakazawa, p. 170, fig. 145.10-145.15.

Material. Rarely recorded in samples SR-4, MV-12 and TO-A-6. The description is based on a right valves preserved as mould from sample SR-4 (PIMUZ 30695).

Description. Shell equivalved, moderately inflated, subtrigonal, slightly longer than high and inequilateral. Umbo slightly prosogyrate. Anterior and posterior margin truncated. Shell with sharp umbonal ridge. Surface smooth.

Discussion. The material at hand agrees well in all external morphological features of $N$. laevigatus, which is a widely reported species in Lower and Middle Triassic rocks. Neoschizodus laevigatus shows a high variability in its morphological characters. Accordingly, it is unclear whether the wide geographical and stratigraphic range of this species is a real phenomenon or rather an effect of its morphological indistinctness.

Ecology. Neoschizodus laevigatus was a shallow infaunal suspension feeder (Hautmann et al. 2013).

Superorder HETERODONTA Neumayr, 1884

Order VENEROIDA Adams and Adams, 1856

Superfamily LUCINOIDEA Fleming, 1828

Family LUCINIDAE Fleming, 1828

Genus SINBADIELLA Hautmann and Nützel, 2005

Sinbadiella pygmaea Hautmann and Nützel, 2005 Figure $13 \mathrm{~F}$

*2005 Sinbadiella pygmaea Hautmann and Nützel, p. 1133, pl. 1 figs 1-20, text-fig. 2.

Material. Rarely recorded in samples SR-2 and TO-A-1. The description is based on the well-preserved specimen PIMUZ 30693.

Description. Shell equivalved, moderately inflated, subquadrate in outline, slightly longer than high. Anterior margin extended, posterior margin blunt. Umbones strongly prosogyrate and placed at about 40 per cent of the dorsal margin.
Lunule deep. Ornamentation and internal features not observed.

Discussion. This species is easily identified by its prosogyrate umbo and its deep lunule. The material found herein agrees well with the specimens from the Sinbad Formation figured in Hautmann and Nützel (2005).

Ecology. Having been assigned tentatively to the family Lucinidae, S. pygmaea was possibly a shallow-burrowing infaunal chemosymbiotic bivalve (Hautmann and Nützel 2005).

Family MACTROMYIDAE Cox, 1929

Genus UNICARDIUM Orbigny, 1850

Unicardium? sp. A

Figure $13 \mathrm{H}$

Material. External mould of one left valve from sample DH-1-gs2.

Description. Valve well inflated, subelliptical in outline. Umbo wide, slightly prosogyrate, placed at the midst of dorsal margin.

Discussion. Generic identification is tentative due to the very few observable morphological criteria and the limited amount of material. However, the specimen is clearly distinguished by its broad umbo from other superficially similar forms such as the herein-described species of Unionites. The external morphology is similar to Middle Triassic species assigned to Unicardium (e.g. Unicardium schmidi Geinitz, 1842), in which it is provisionally placed.

Superfamily CRASSATELLOIDEA de Férussac, 1822 Family MYOPHORICARDIIDAE Chavan in Vokes, 1967

Genus SEMENTICONCHA Hautmann et al., 2013

Sementiconcha recuperator Hautmann et al., 2013 Figure 13G

*2013 Sementiconcha recuperator Hautmann et al., p. 284, fig. 8A-L.

Material. One specimen from SR-4 (PIMUZ 30694).

Description. Shell equivalved, moderately inflated, with sharp diagonal carina. Outline of valves subrectangular, posteriorly truncated. Posterior dorsal margin straight. Beak located at anterior 30 per cent of dorsal margin. Umbones prosogyrate. Lunule well developed. Ornamentation and internal features not observed. 
Discussion. Although only one specimen is available, species identification is possible on the basis of the welldeveloped carina and the distinctly prosogyrate umbo. This species, originally described from the Spathian Virgin Formation (Hautmann et al. 2013), occurs there in high numbers in subtidal low-energy deposits (Hautmann et al. 2013). The record in the Sinbad Formation reveals that this species was already present in Smithian of the western USA.

Ecology. Sementiconcha recuperator was a shallow-burrowing suspension feeder (Hautmann et al. 2013).

\section{Gastropods}

by Richard Hofmann and Alexander Nützels.

Class GASTROPODA Cuvier, 1797-1798

Order VETIGASTROPODA Salvini-Plawen, 1980

Superfamily TROCHONEMATOIDEA Zittel, 1895

Family LOPHOSPIRIDAE Wenz, 1938

Genus WORTHENIA De Koninck, 1883

Remarks. The Palaeozoic genus Worthenia and the Triassic genus Wortheniella Schwardt, 1992 closely resemble each other and are distinguished by the morphology of the early teleoconch. The early teleoconch of the few Early
Triassic species assigned to Worthenia are unknown. Thus, these Early Triassic species are left in the previously suggested systematic position until better preserved material becomes available.

\section{Worthenia windowblindensis Batten and Stokes, 1986} Figure $14 \mathrm{~A}$
${ }^{\star} 1986$ Worthenia windowblindensis n. sp. Batten and Stokes, p. 6, figs 1-3.

2005 Worthenia windowblindensis Nützel and Schulbert, p. 507 , fig. $11 \mathrm{H}$.

Material. One specimen recorded from sample DH-1-3 (PIMUZ 30704).

Description. Relatively low-spired shell with gradate whorl profile. Three whorls developed with well-incised sutures. Ornamentation with at least three equidistant spiral chords with intercalated fine spiral threads. Upper whorl face with broad shallow ramp that is flat to slightly concave. Selenizone was probably situated at edge of ramp. Collabral ornament absent. First whorl and aperture not observed.

Remarks. Worthenia windowblindensis is easily recognized by the missing collabral ornament, which is otherwise characteristic for the genus (Batten and Stokes 1986). This species has been erected based on material from the Sinbad Formation (Batten and Stokes 1986), which represents a shallow marine equivalent of the occurrence studied herein.
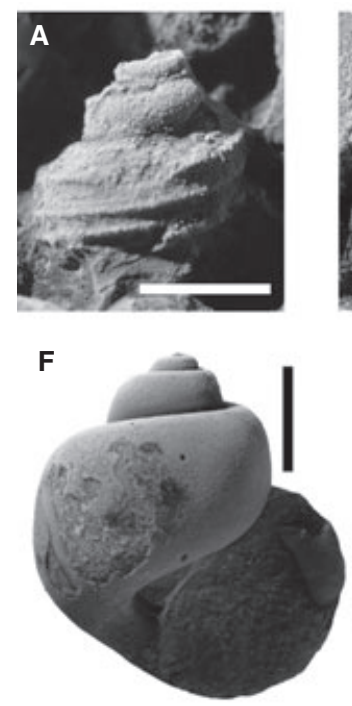

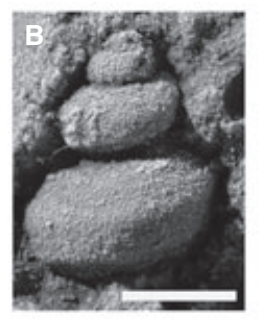

G

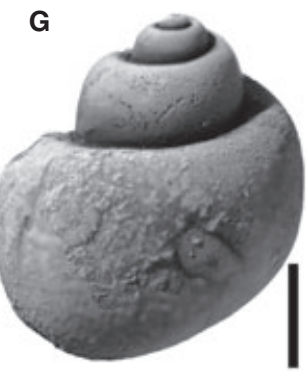

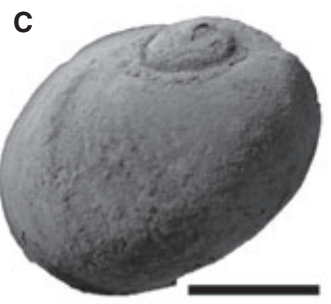

D
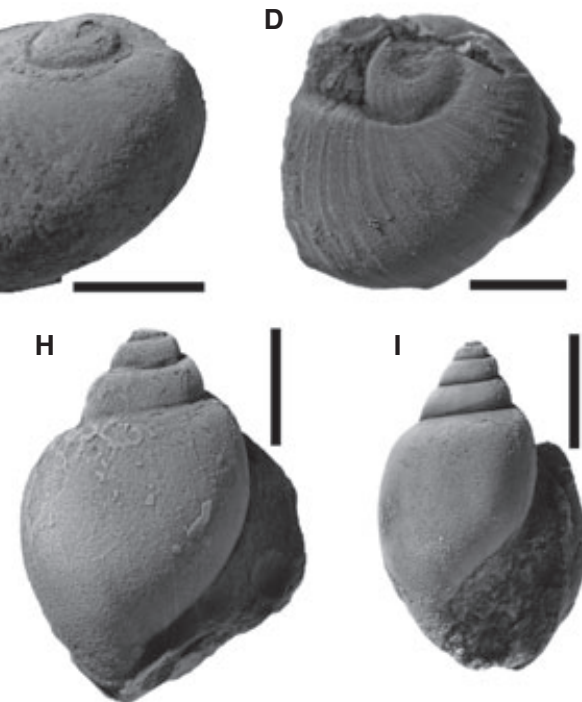

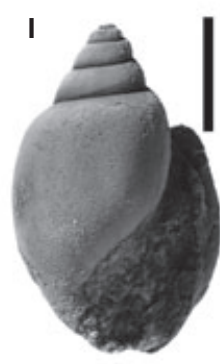

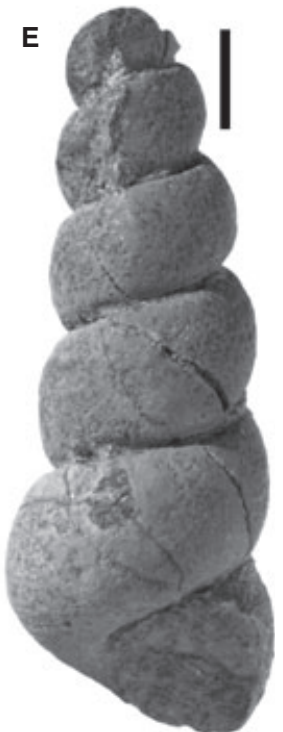

FIG. 14. A, Worthenia windowblindensis, sample DH-1-3, PIMUZ 30704. B, Chartronella sp. A, sample SR-3, PIMUZ 30705. C, Abrekopsis cf. depressispirus, sample SR-3, PIMUZ 30706. D, Neritaria costata, sample, SR-4, PIMUZ 30707. E, Polygyrina sp. A, sample DH-1-gs2, PIMUZ 30708. F-G, Laubopsis? sp. A, sample DH-1-gs1, PIMUZ 30709. F, apertural view. G, lateral view. H, Strobeus batteni, sample DH-1-gs-1, PIMUZ 30710, apertural view. I, Strobeus batteni, DH-1-gs-1, PIMUZ 30711, apertural view. Scale bars represent $2 \mathrm{~mm}$ in $\mathrm{A}-\mathrm{B}, \mathrm{D} ; 4 \mathrm{~mm}$ in $\mathrm{C} ; 5 \mathrm{~mm}$ in $\mathrm{E}-\mathrm{G} ; 10 \mathrm{~mm}$ in $\mathrm{H}-\mathrm{I}$. 
Ecology. Worthenia windowblindensis was an epifaunal detritus feeder.

\author{
Superfamily TURBINOIDEA Rafinesque, 1815 \\ Family ATAPHRIDAE Cossmann, 1915
}

Genus CHARTRONELLA Cossmann, 1902

\section{Chartronella? sp. A}

Figure 14B

Material. Recorded in very low numbers in the lower part of the Sinbad Formation from samples TO-A-1, SR-1, SR-2 and SR-3. The description is based on specimen PIMUZ 30705.

Description. Turbiniform, relatively high-spired shell with deeply incised sutures. Whorls convex, somewhat angulated at or slightly above mid-whorl, moderately inflated with ramp.

Remarks. Given the poor state of preservation, identification of the material at hand is not unequivocal. The only genus reported from the Sinbad Formation by Batten and Stokes (1986), which agrees with the general shape and the presence of a subsutural ramp, is Chartronella.

Ecology. Chartronella sp. A is interpreted as an epifaunal detritus feeder.

\section{Order NERITIMORPHA Koken, 1896 Superfamily NERITOPSOIDEA Gray, 1847 (= Rafinesque, 1815) Family TRICOLNATICOPSIDAE Bandel, 2007}

Genus LAUBOPSIS Bandel, 2007

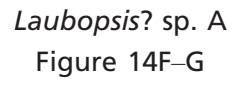

Material. Very common in samples DH-1-gs-1 and DH-1-gs2. The description is based on abundant steinkerns from sample DH-1-gs2.

Description. Shell turbiniform, low-spired with convex inflated, somewhat shouldered whorls. Last whorl much higher than spire. Suture deeply incised. Periphery of mature whorls flattened. Aperture subcircular, oblique, somewhat higher than wide. Base phaneromphalous, possibly with umbilical plug.

Remarks. The present material consists of numerous specimens, which form a distinct species in the collection from beds DH-1-gs1 and DH-1-gs2. However, based on steinkerns, it is almost impossible to determine this spe-

cies properly. It shares the general shape, the phaneromphalous condition and the form of the aperture with the neritimorph genus Laubopsis, which was originally described from the Late Triassic Cassian Formation of the Dolomites (Bandel 2007). Some of the present specimens seem to have an umbilical plug, which could also support a placement within neritimorphs. However, shells like this are also known from other gastropods such as naticids or certain vetigastropods.

Ecology. Epifaunal, probably grazers or detritus feeders.

Superfamily NERITOIDEA Rafinesque, 1815
Family NERITIDAE Rafinesque, 1815

Genus ABREKOPSIS Kaim, 2009

Abrekopsis cf. depressispirus (Batten and Stokes, 1986) Figure $14 \mathrm{C}$

cf. 1986 Naticopsis depresispirus n. sp., Batten and Stokes, p. 12, figs 11-13.

cf. 2009 Abrekopsis depressispirus, Kaim, p. 150, fig. 140.

Material. Fairly abundant in samples SR-1, SR-2, MV-2, DV-3, otherwise recorded in smaller numbers in samples SR-3 and TO-A-1 to TO-A-6. The description is based on a well-preserved specimen from sample SR-3 (PIMUZ 30706).

Description. Shell globose, egg-shaped, very low-spired. Whorls rounded, rapidly increasing, embracing most of the preceding whorls. Shallow suture. Faint prosocline growth lines.

Discussion. This form is probably conspecific with $A$. depressispirus (Batten and Stokes 1986; Kaim 2009). However, because the aperture and the apex are not preserved in our material, we prefer to present it in open nomenclature. This form is known from Early Triassic of the western USA (Batten and Stokes 1986) and Far East Russia (Kaim 2009). Similar neritimorphs have repeatedly been documented from Early Triassic formations of various areas, for example, Naticopsis sp. from the Salt Range, Pakistan, Naticopsis from Oman (Kaim et al. 2013; Wheeley and Twitchett 2005). Due to a low number of shell characters, their taxonomy is very difficult especially if the preservation is not excellent.

Family NERITARIIDAE Wenz, 1938 Subfamily NERITARIINAE Wenz, 1938

Genus NERITARIA Koken, 1892 


\section{Neritaria costata Batten and Stokes, 1986}

Figure 14D

${ }^{\star} 1986$ Neritaria costata Batten and Stokes, p. 16, figs 20, 21.

Material. Recorded with one specimen in sample SR-4 (PIMUZ 30707).

Description. Small depressed neritiform shell with rapidly expanding whorls and deeply incised suture. Ornamentation consists of prosocline, slightly prosocyrt axial ribs. First whorl and aperture not observed.

Remarks. This species was first described from the same locality by Batten and Stokes (1986), which is also the only locality from which it has thus far been reported. Neritimorphs with prominent axial ribs are not very diverse in the Early Triassic. Only 'Natiria' costata is frequently observed in upper Werfen Formation of the Dolomites (Nützel 2005). Bandel (2007) erected two Late Triassic genera, which have a prominent axial ornament: Colubrellopsis and Ladinaticella. Neritaria costata may belong to one of these genera. However, the type species of Neritaria is entirely smooth.

Ecology. Neritaria aequicostata was an epifaunal detritus feeder.

Order CAENOGASTROPODA Cox, 1962

Superfamily ACTEONINOIDEA Cossmann, 1895

Family SOLENISCIDAE Knight, 1931

Genus STROBEUS de Koninck, 1881

Strobeus batteni Kaim et al., 2013

Figure $14 \mathrm{H}$

1986 Strobeus cf. paludinaeformis (Hall); Batten and Stokes, p. 29, figs 49-51.

2005 Soleniscus sp. or Strobeus sp., Nützel, p. 441, fig. 7 middle and right.

2005 Soleniscus?, Wheeley and Twitchett, p. 40, fig. 2L, M.

2010 '?Naticopsis-?Omphaloptycha', Brayard et al., p. 148, fig. 1A, B.

2013 Strobeus batteni, Kaim et al. p. 6, fig. 6C-E, I.

Material. Very common in samples DH-1-gs1, DH-1-gs2 and DH-1-9. The description is based on abundant steinkerns from the sample DH-1-gs2.

Description. Shell egg-shaped, varying from elongated to rather bulbous, low-spired with last whorl much higher than spire. Spire acutely conical. Whorls convex evenly rounded, embracing some- what below suture. Suture distinct. Aperture tear drop-shaped, round anteriorly, acute posteriorly. Parietal lip convex. Columellar fold present, but rarely visible. Aperture probably with weak anterior canal. Growth lines more or less orthocline to slightly prosocyrt.

Remarks. The present material seems to be close to Strobeus batteni as described by Kaim et al. (2013) from the early Smithian of Pakistan. These authors also included material from the Sinbad Formation, which was described as Strobeus cf. paludinaeformis by Batten and Stokes (1986). However, the assignment is somewhat tentative due to the steinkern preservation of the present material. There are broader, bulbous specimens (Fig. 14H) as well as somewhat more slender specimens (Fig. 14I) present in our collection. We interpret this as intraspecific variability although it is possible that two species are present.

Ecology. Epifaunal to semi-infaunal, detritus or sediment feeders, microcarnivory possible.

Family POLYGYRINIDAE Bandel, 1993

Genus POLYGYRINA Koken, 1892

Poylgyrina sp. A

Figure 14E

?1986 Coelostylina species b, Batten and Stokes, p. 25, fig. 40.

2010 'Polygyrina', Brayard et al., p. 148, figs 1C-H, 3.

Material. Rather rare in the samples TO-A-1, TO-A-2, SR-2, SR-3, DH-1-0, DH-1-gs2. Fairly abundant in the samples MV-2 and TO-A-2. The description is based on the comparatively large specimens from sample DH-1-gs2 (PIMUZ 30708).

Description. High-spired shell. Whorls smooth, convex, evenly inflated. Suture well-incised and straight. Protoconch and aperture missing.

Remarks. Similar high-spired gastropods of the Early Triassic were traditionally assigned to the genus Coelostylina. However, most of the Early Triassic material assigned to Coelostylina is preserved as steinkerns and provides very few criteria to facilitate a precise genus and species identification. Accordingly, species tend to be lumped into poorly defined dustbin genera such as Coelostylina or Polygyrina (Nützel 2005). The same is true for the material of the Sinbad Formation and the Thaynes Formation. The specimens observed in this study are very likely conspecific with 'Polgyrina' reported in Brayard et al. (2010) from the same bed as the specimen figured herein, but no systematic discussion accompanied that study. Coelostylina spe- 
cies b in Batten and Stokes (1986) from the Sinbad Limestone (San Rafael Swell) agrees well with our material and could be conspecific although it has a slightly larger apical angle. The Late Triassic type species of Coelostylina and Omphaloptycha are small- to medium-sized shells, which have a much lower spire than the present material, that is, the last whorl exceeds the spire height by far in both genera. Moreover, they have umbilical niches. The general shape of the present material is close to that of Polygyrina lommeli from the Late Triassic Cassian Formation where it is most abundant in autochthonous soft bottom communities or algal meadow assemblages (Fürsich and Wendt 1977). However, material with shell preservation is required for a precise taxonomic assignment.

Ecology. Polygyrina was an epifaunal detritus feeder.

\author{
Brachiopods \\ by Richard Hofmann
}

\author{
Phylum BRACHIOPODA Dumeril, 1806 \\ Class LINGULATA Goryansky and Popov, 1985 \\ Order LINGUILIDA Waagen, 1895 \\ Family LINGULIDAE Menke, 1828
}

\section{Genus LINGULARIA Biernat and Emig, 1993}

Discussion. Lower Triassic lingulids were traditionally (Bittner 1899; Newell and Kummel 1942) but also in more recent studies (Rodland and Bottjer 2001, Hofmann et al. 2013b) placed in Lingula. Biernat and Emig (1993) pointed out that Palaeozoic and many Mesozoic 'Lingula' show marked internal differences to extant species of the genus, such as the shape of the posterior adductor muscle, the size of the lophophoral cavity and shorter ventral vascular lateralia. The state of preservation in our material does not allow identification of these features with certainty. However, the conspicuous, relatively deep paired grooves (Fig. 15A) along the midline join at the posterior end of the shell and are suggestive of Lingularia because they imply the presence of a symmetrical heart-shaped adductor muscle scar diagnostic for this genus (Biernat and Emig 1993). In Lingula, this structure is reduced to one lateral scar, which results in curved continuous pedicle grooves.

\section{Lingularia borealis (Bittner, 1899)}

\section{Figure 15A}

${ }^{\star} 1899$ Lingula borealis nov. spec.; Bittner, p. 25, pl. 4, figs $1-7$.
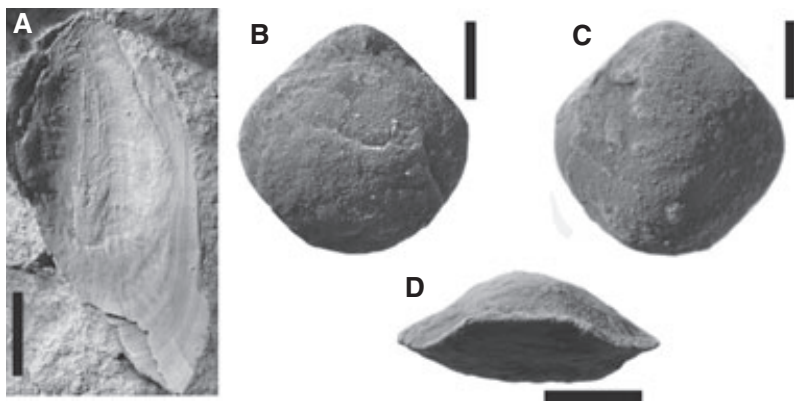

FIG. 15. A, Lingularia borealis, sample DV-1, ventral valve, PIMUZ 30701. B-D, Obnixia thaynesiana, sample CP-102. B, dorsal view, PIMUZ 30703. C, ventral view, PIMUZ 30703. D, anterior view, PIMUZ 30702. All scale bars represent $3 \mathrm{~mm}$.

1942 Lingula borealis Bittner; Newell and Kummel, p. 953 , pl. 2, figs $1-4$.

?1993 Lingularia similis sp. n.; Biernat and Emig, p. 11, fig. 3.

2013 Lingula borealis Bittner; Hofmann et al., p. 868, fig. 8.24.

Material. Recorded from the samples DH-1-0, DH-1-1a, DH-13, DV-1, DV-2, DH-3-1.

Description. Shells elongate and oval in outline, lateral margins subparallel, posterior parts of both valves weakly inflated along median longitudinal line. Shell surface generally smooth except for concentric fine growth lines. Ventral valve with parallel pedicle ridge terminating towards the posterior part.

Discussion. The specimens from the Thaynes Group agree well with figures and the description of 'Lingula' borealis (Bittner 1899; Newell and Kummel 1942), which has been included in the type species of Lingularia ( $L$. similis) by Biernat and Emig (1993). This allocation remains dubious because it was based on the fact that Bittner (1899) did not provide descriptions of criteria considered as diagnostic by Biernat and Emig (1993). This might be unfortunate, but does not justify priority of their new species $L$. similis. If Bittner's material turns out to share the same diagnostic characteristics with $L$. similis, $L$. borealis would be the older and thus valid synonym (Holmer and Bengtson 2009). In our view, $L$. borealis is, thus, a valid species, and the figures provided by Bittner (1899) and Newell and Kummel (1942) allow a precise allocation of our material.

Peng and Shi (2008) erected the new species Sinolingularia huananensis, which is very similar to L. borealis. This has been also noted by Peng and Shi (2008) who tentatively assigned 'some [...] Early Triassic Lingula borealis into the new species Sinolingularia huananensis'. However, without a proper synonymy list, it remains unclear which published Lingula borealis' were 
assigned to S. huananensis. According to Peng and Shi (2008), the diagnostic differences between Lingularia and Sinolingularia are the presence of separated dorsal anterolateral muscle scars and posteriorly extended pedicle grooves in the ventral valve. Our material does not allow a clear differentiation because the dorsal valves are too poorly preserved. However, because Biernat and Emig (1993) noted the close morphological similarity of the specimens of Newell and Kummel (1942) to L. similis, we prefer to include our material in Lingularia.

Lingularia borealis has been frequently reported from the Panthalassa margin (Bittner 1899; Rodland and Bottjer 2001; Shigeta et al. 2009). The prolific appearance of Lingularia in the aftermath of the end-Permian mass extinction has been linked to particular ecological conditions, environmental stress or a combination of both factors (Rodland and Bottjer 2001). Lingularia is particularly abundant in the Griesbachian to Dienerian Dinwoody Formation (Rodland and Bottjer 2001). Our studies (Hofmann et al. 2013a) suggest that the wide occurrence of $L$. borealis may be attributed to a combination facies effects and ecospace vacation, which enables eurytopic taxa such as Lingularia to thrive in habitats, which are inhabited by more specialized taxa during background times. Observations in the Dinwoody Formation indicate that $L$. borealis becomes rare or absent as soon as other taxa became established in benthic communities. This supports the hypothesis that the proliferation of Lingularia seems, besides certain facies effects, a real phenomenon that is attributed to a preceding extinction event. With respect to this consideration, it is interesting to note that L. borealis is exclusively recorded in lower Smithian strata in the investigated area, which could indicate that benthic ecosystems may have been affected by faunal decimation just before the initial Thaynes transgression.

Ecology. Based on the ecology of similar extant species of Lingula, L. borealis is interpreted as a shallow infaunal suspension feeder.

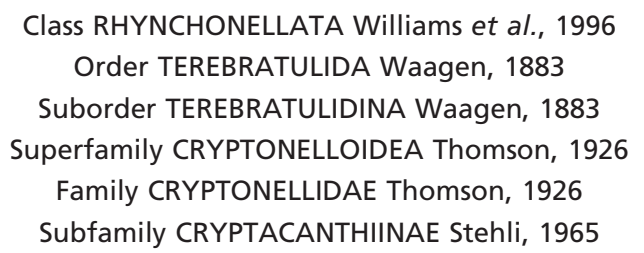

Genus OBNIXIA Hoover, 1979

Obnixia thaynesiana (Girty, 1927)

Figure 15B-D

\footnotetext{
*1927 Terebratula thaynesiana n. sp., Girty, p. 435, pl. 30, figs 8-11.

?1979 Protogusarella smithi n. sp. Perry and Chatterton, p. 317, pl. 2, figs 1-32, text-figs 4-6.

1979 Obnixia thaynesiana (Girty, 1927), Hoover, p. 12, pl. 2 figs $8-27$, pl. 3 figs $1-13$.
}

Material. This species is exclusively record in sample CP-102. The description is based on the well-preserved specimens PIMUZ 30703 and 30702.

Description. Shell rounded subpentagonal, length and width being subequal. Ventral valve notably more convex than dorsal valve. Apex suberect. Commissure wide uniplicate. Surface smooth.

Remarks. This species is exclusively observed from the Early Triassic of the western USA (Hoover 1979). Very few terebratulide brachiopod species, on which Hoover (1979) gave a systematic overview, are known from the Early Triassic of the western USA. The material observed herein agrees very well with the features and figures of O. thaynesiana, which was originally introduced as T. thaynesiana by Girty (1927). Although the internal morphology has not been figured in Girty (1927), we follow Hoover (1979) in suggesting that the material of Girty (1927) is conspecific with his specimens. A very similar form, P. smithi, was erected by Perry and Chatterton (1979). This species probably differs from T. thaynesiana in being more equiconvex, having a weaker ventral fold, possessing a dorsal sulcus and lacking a medial plication. However, Girty (1927) noted that his T. thaynesiana is morphological highly variable. Unfortunately, he did not figure internal features, which are important for a correct identification. The internal features figured by Hoover (1979) refer to the paralectotype, and thus, it cannot be excluded that P. smithi and O. thaynesiana (sensu Girty 1927) are conspecific. If this is the case (1) P. smithi is an obsolete species, and (2) Obnixia takes priority over Protogusarella or vice versa. Both genera were erected in 1979, and it has to be worked out which one was published earlier.

Ecology. Obnixia thaynesiana was a pedunculate epifaunal suspension feeder.

\section{PALAEOECOLOGY OF THE THAYNES GROUP AND SINBAD FORMATION}

In the Smithian part of the Thaynes Group and Sinbad Formation, the most dominant benthic guilds (sensu Aberhan 1994) are shallow infaunal, epibyssate and endobyssate epifaunal (bivalves) suspension feeders as well as 
epifaunal grazers (gastropods). The gastropod Strobeus, which is locally abundant, probably represents an epi- to semi-infaunal carnivore. Free-lying suspension feeders (Pernopecten) are also present, but rare. Sinbadiella pygmaea was possibly an infaunal chemosymbiotic lucinid bivalve (Hautmann and Nützel 2005). Although not recognized in this study, sponges as cementing suspension feeders became definitely established by Smithian times in the western USA (Brayard et al. 2011). Ophiuroids and asteroids, which are epifaunal carnivores or detritus feeders, were very rarely observed and were not recognized in samples contributing to the associations studied herein. However, microfacies analysis that is currently carried out (Vennin et al. in. prep.) demonstrates that they may be extremely abundant in thin sections. This adds up to 9 of 13 typically Mesozoic benthic guilds (Aberhan 1994). The ecological spectrum of the Spathian part of the Thaynes Formation (sections MV and CP) is the same with the only exception that crinoids and articulate brachiopods are locally abundant. Brachiopods are absent before the Spathian in the investigated sections.

Faunal associations and assemblages are obtained by Qmode cluster analysis (Fig. 16), which groups individual samples based on the occurrence and abundance of taxa within the data set. Seven associations and one assemblage (sensu Fürsich 1984) are recognized in the Thaynes Group and the Sinbad Formation. These are characterized in the following paragraphs.

Unionites cf. canalensis association. This association (Fig. 17A) is represented by samples DV-1 and DV-2. The trophic nucleus comprises the species Unionites cf. canalensis, L. borealis and Eumorphotis mutliformis. Also recorded is the infaunal suspension feeding bivalve Unionites cf. fassaensis. Species richness is 3 in both samples. Dominance is moderate with $D$ values ranging from 0.52 to 0.55 . The ecological spectrum comprises epifaunal and infaunal suspension feeders. The rarefaction curve indicates that further sampling would not have significantly increased alpha-diversity of this association. Although the low number of samples and specimens impedes reliable statements, this association shows a very low alpha- and guild diversity, and it is confined to the lowermost Smithian interval of the investigated area.

Eumorphotis ericius association. This association (Fig. 17B) comprises samples CP-2, CP-3, CP-5 and MV10. The trophic nucleus involves E. ericius and E. mutliformis. The remaining species are Bakevellia cf. exporrecta, L. occidanea, Unionites cf. canalensis and Permophorus cf. bregeri. Sample species richness ranges from 1 to 5 (mean 2.75). Dominance ranges from 0.33 to 1 (mean 0.69). Guild diversity is 3 with epifaunal suspension feeding biv- alves representing the main constituents. Semi-infaunal and infaunal bivalves play only a minor role, especially in terms of absolute abundance of guilds. The rarefaction curve indicates that the overall diversity of six species approximates expected diversity. The E. ericius association is most notably recorded in strata, which are early Spathian in age. Abundant occurrences of large E. ericius and E. multiformis, which form thick-bedded bioclastic limestones, were observed in all sections exposing strata of this time interval, which suggests that these species experienced a rapid expansion, at least in mid- and inner shelf habitats.

Bakevellia cf. exporrecta association. This association (Fig. 17C) is represented by samples CP-101, MV-4, MV3, CP-4, MV-12, MV-7, CP-0, MV-9 and MV-3-2. Bakevellia cf. exporrecta constitutes its trophic nucleus. All other species (E. ericius, E. multiformis, E. hinnitidea, L. occidanea, N. laevigatus, Unionites cf. fassaensis, Promysidiella sp. A and Permophorus cf. bregeri) are recorded in very small numbers. Sample diversity ranges from 1 to 5 (mean 2.3). Dominance values range from 0.34 to 1 (mean 0.69). Guild diversity is 3 with epifaunal, semiinfaunal and infaunal suspension feeding bivalves recorded. Epifaunal bivalves dominate in terms of species per guild, whereas semi-infaunal bivalves clearly dominate in terms of abundance. The rarefaction curve indicates that the merged diversity of nine species is slightly lower than expected diversity. This association is limited to the lowermost Spathian in all sections where strata of this time interval are exposed.

Strobeus batteni association. The Strobeus batteni association (Fig. 17D) comprises samples DH-1-gs1 and gDH-1-s2. The trophic nucleus includes Strobeus batteni and Laubopsis? sp. A. C. loczyi may be abundant. All other species (L. occidanea, Polygyrina sp. A and Unicardium sp. A) are rare. Sample diversity is $4-5$ (mean 4.5 ), and dominance is $0.39-0.41$ (mean 0.4 ). The trophic guild diversity is 4 with epifaunal grazers, carnivores and suspension feeders as well as infaunal suspension feeders that are balanced in terms of species per guild. In absolute abundances, infaunal suspension feeders are merely an accessory element. The overall diversity of six taxa seems to reflect the actual diversity as indicated by the rarefaction curve. This association is confined to an interval of the section DH-1, which exposes shales intercalated with thin limestone beds.

Leptochondria occidanea association. This association (Fig. 18A) is represented by samples CP-8, CP-7, CP-1, TO-A-5 and DH-1-3. The trophic nucleus is formed by L. occidanea. The second most common species is C. loczyi. All other species (L. borealis, Abrekopsis cf. depressispirus, Pernopecten sp. A, Bakevellia cf. exporrecta, 


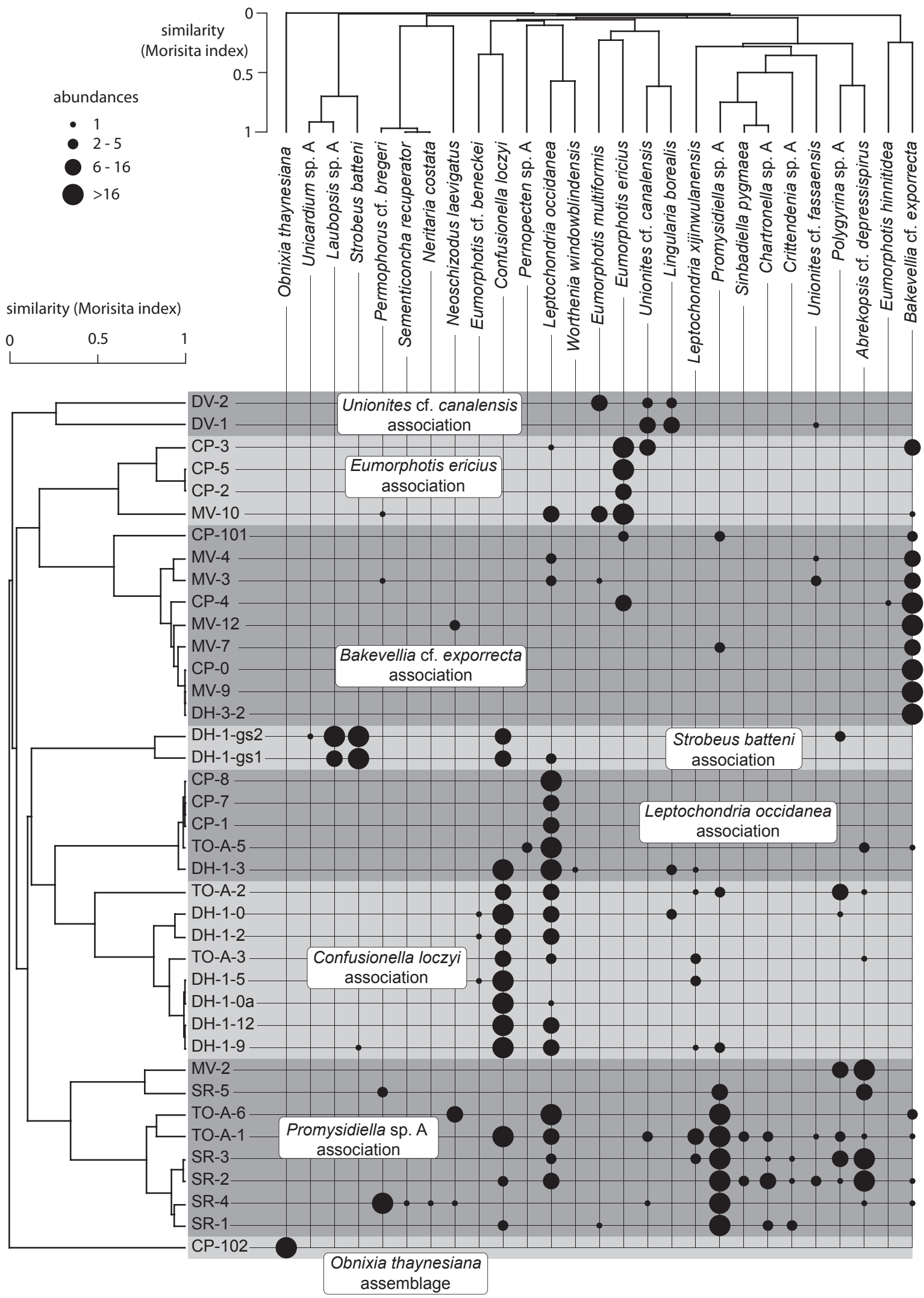

FIG. 16. Q-mode (samples) and R-mode (species) cluster analysis using the unweighted paired group algorithm and Morisita index of similarity. Classes of abundances (circle size) represent the quartiles of absolute abundance frequencies. 
L. xijinwulanensis and $W$. windowblindensis) are very rare. Sample diversity ranges from 1 to 5 (mean 2.4), and dominance values range from 0.66 to 1 (mean 0.89). Trophic guild diversity is 5, with free-lying, epifaunal, semi-infaunal and infaunal suspension feeders as well as
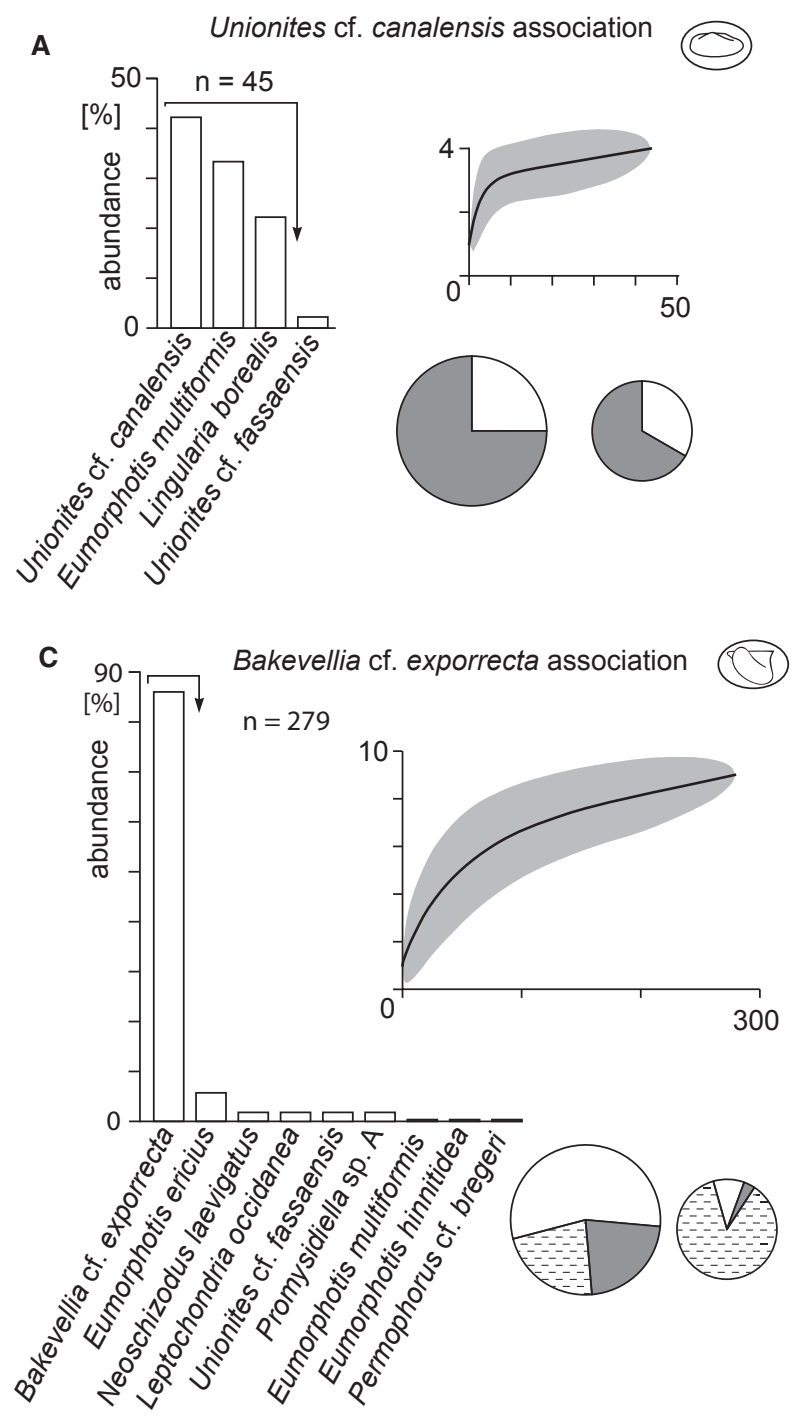

Legend

Ecological guilds
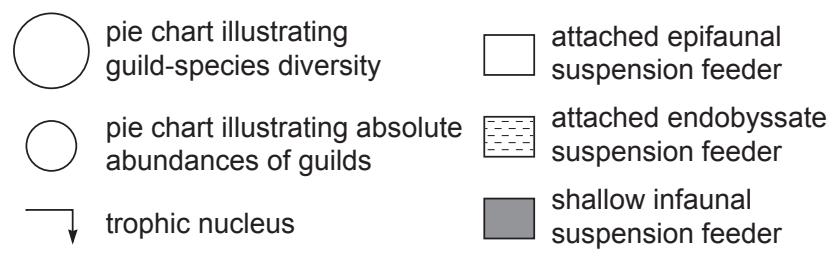

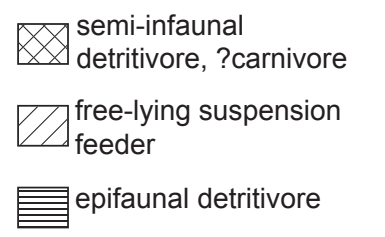

epifaunal grazers. Whereas the species per guild spectrum is balanced, the absolute abundance pattern shows that epifaunal suspension feeding bivalves are overwhelmingly dominant in this association. The overall diversity of eight taxa slightly underestimates the expected diversity as

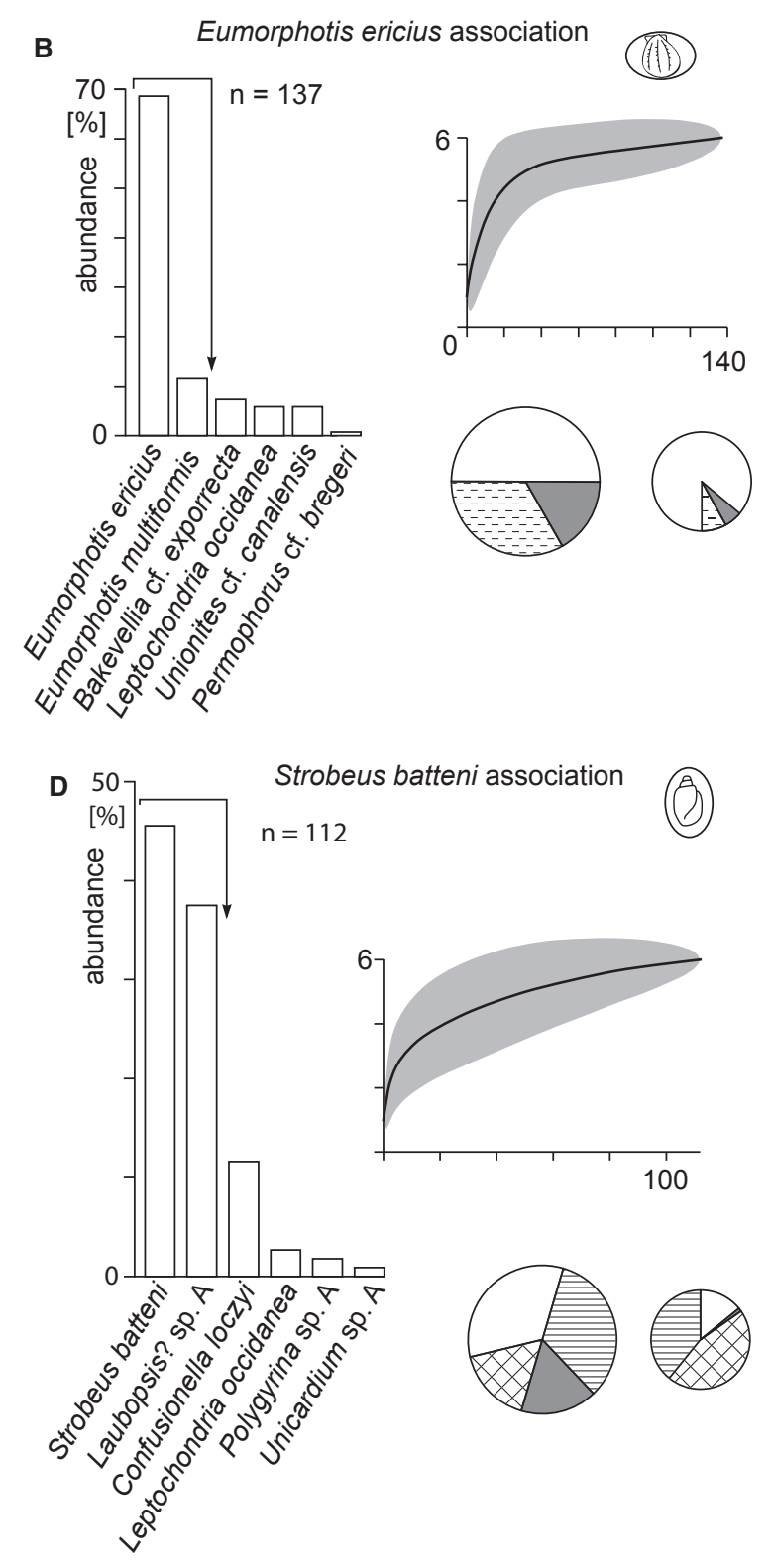

FIG. 17. Features of the benthic association between the Thaynes Group and Sinbad Formation. A, Unionites cf. canalensis association. B, Eumorphotis ericius association. C, Bakevellia cf. exporrecta association. D, Strobeus batteni association. 


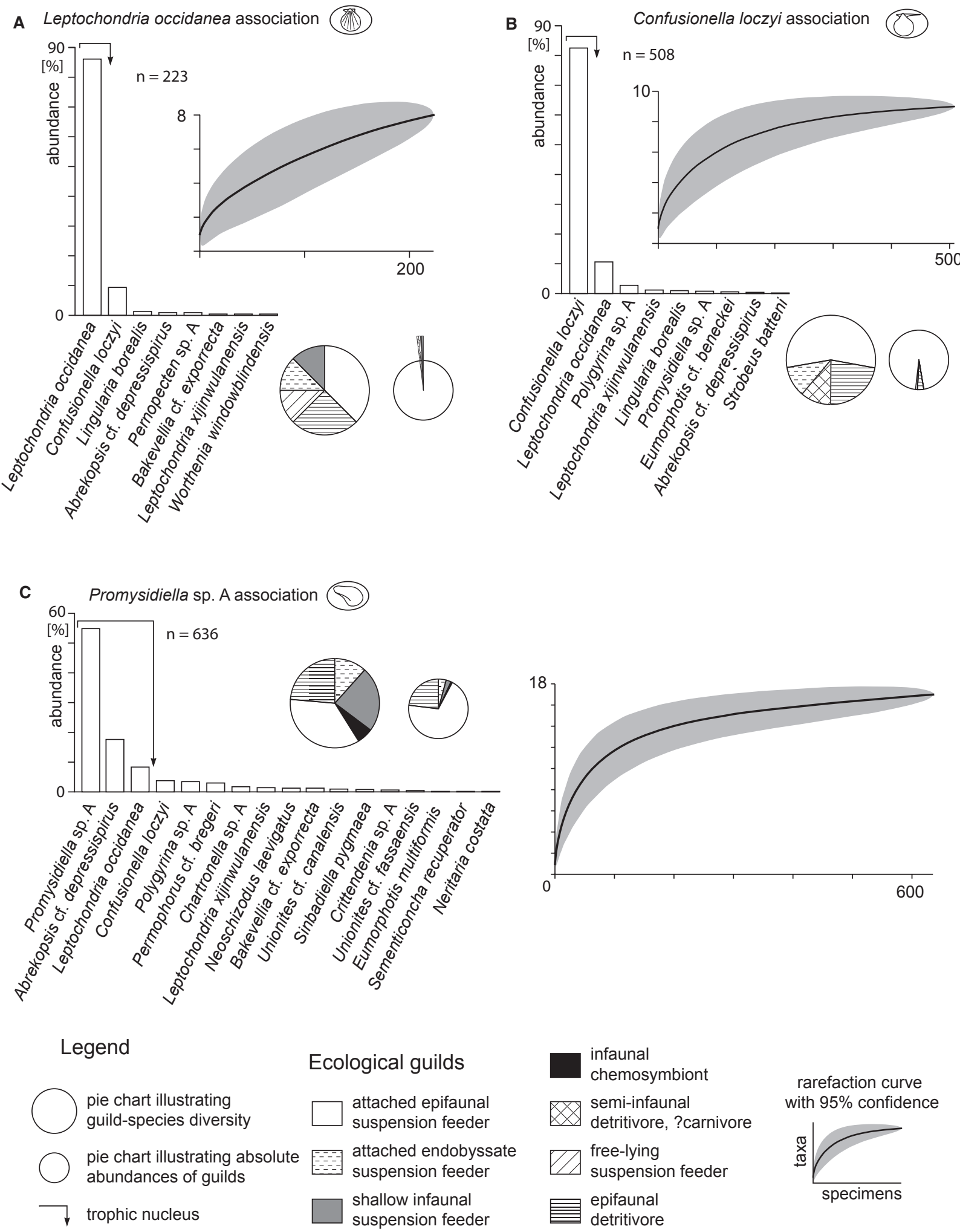

FIG. 18. Features of the benthic association of the Thaynes Group and Sinbad Formation. A, Leptochnodria occidanea association. B, Confusionella loczyi association. C, Promysidiella sp. A association. 
indicated by the rarefaction curve. The L. occidanea association occurs in both inner and outer shelf settings and is not confined to a certain stratigraphic level.

Confusionella loczyi association. This association (Fig. 18B) is recorded by samples TO-A-2, DH-1-0, DH1-2, TO-A-3, DH-1-5, DH-1-0a, DH-1-12 and DH-1-9. The trophic nucleus is represented by C. loczyi. Also recorded but not particularly abundant are the species L. occidanea and Polygyrina sp. A. Accessory elements are the species L. xijinwulanensis, L. borealis, Promysidiella sp. A, Eumorphotis cf. beneckei, Abrekopsis cf. depressispirus and Strobeus batteni. Diversity ranges from 2 to 6 (mean 3.6). Dominance values range from 0.28 to 0.94 (mean 0.57). Trophic guild diversity is 4 , with epifaunal and semi-infaunal suspension feeders being present in addition to epifaunal grazers and carnivores. Species guild diversity is balanced, but the epifaunal suspension feeders form the numerically dominating group. The well-levelled rarefaction curve indicates that the overall diversity of nine species in this association is close to the expected diversity. The C. loczyi association is predominantly recorded in outer shelf settings of section $\mathrm{DH}-1$ and to far lesser extent in section TO-A.

Promysidiella sp. A association. This association (Fig. 18C) is recorded by samples: SR-1, SR-2, SR-3, SR4, SR-5, MV-2, TO-A-6 and TO-A-1. The trophic nucleus is represented by the species Promysidiella sp. A, Abrekopsis cf. depressispirus and L. occidanea. Minor elements are C. loczyi, Polygyrina sp. A and Permophorus cf. bregeri.
The remaining species are very rare (Chartronella sp. A, L. xijinwulanensis, N. laevigatus, Bakevellia cf. exporrecta, Unionites cf. canalensis, S. pygmaea, Crittendenia sp. A, Unionites cf. fassaensis, E. multiformis, S. recuperator, N. costata). Sample diversity ranges from 2 to 10 (mean 6.1 ), and dominance values range from 0.24 to 0.67 (mean 0.47). Trophic guild diversity is 4 and involves epifaunal, semi-infaunal and infaunal suspension feeders, as well as epifaunal grazers. The species per guild diversity is balanced, whereas in terms of absolute abundance, epifaunal bivalves are clearly dominating. The well-levelled rarefaction curve suggests that the overall diversity of 17 species matches the expected diversity of this association. This association is largely confined to inner shelf habitats of the Sinbad Formation.

\section{Spatial and temporal trends}

The most notable pattern (Fig. 19) shown by the Smithian data is a distinction between inner and outer shelf communities with some overlap seen in mid-shelf settings. The Promysidiella sp. A association is exclusively found in strata deposited above the storm wave base. The C. loczyi association and the Strobeus batteni and the L. occidanea associations predominate in outer- and midshelf settings of the Confusion Range. The Unionites cf. canalensis association, found exclusively in the basal part of the section at Dog Valley, is recorded just above the oldest ammonoid beds (early Smithian) observed in the area, which could indicate a stratigraphic signal. Section

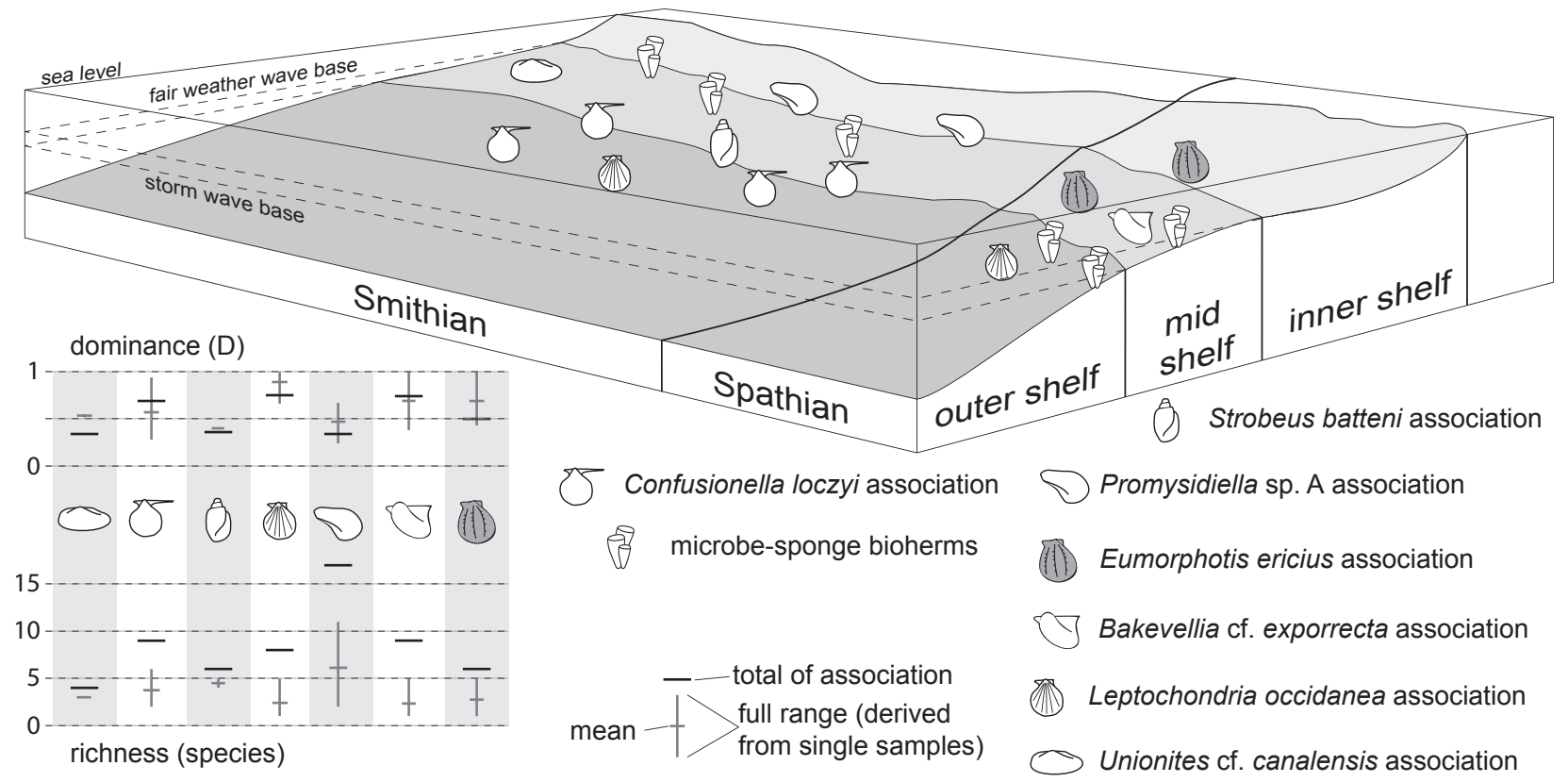

FIG. 19. General distribution of benthic associations from Smithian to Spathian in inner to outer shelf settings. 
DH-1 contains beds rich in benthic fauna from late early to latest Smithian. Faunal composition does not change over the recorded time span. The interfingering of the C. loczyi, Strobeus batteni and L. occidanea associations is most likely related to proximal-distal trends. The Strobeus batteni association is restricted to rhythmic fine-scale interbeddings of marly shales and limestones, which points to a more proximal position in an upper mid-shelf position. The other two associations are exclusively recorded in packstone and grainstone that occur within barren shale intervals, which are typical of mid- and outer shelf settings. Benthic communities were thus not affected by significant turnovers during the Smithian.

Beds of Spathian age indicate a remarkable shift in faunal composition. As observed in all settings, there is a shift from typical Smithian association to associations that are dominated by Bakevellia cf. exporrecta and E. ericius. The latter seems to be more common in thick bioclastic limestones deposited in mid- and inner shelf facies. In the early Spathian, outer shelf deposits again contain the L. occidanea association.

In conjunction with the distribution of the associations (Fig. 19), some trends in alpha-diversity (or sam- ple richness per association) and dominance can be deduced with respect to facies (Fig. 20) and time (stratigraphic age). The Promysidiella sp. A association, which is predominantly observed in inner shelf settings, exhibits the highest mean and bulk diversity. All other associations have a much lower range of sample richness, a lower mean and overall diversity. The exceedingly higher overall diversity of the Promysidiella sp. A association may partly indicate some mixing of communities in the more heterogeneous inner shelf habitats. However, the fact that its species composition is reproduced relatively well in several samples (Fig. 16) suggests that this effect is of minor importance. The E. ericius assemblage dominates in lower Spathian inner shelf environments and is characterized by much lower diversity values. The Bakevellia cf. exporrecta association, which is predominantly recorded in Spathian outer shelf settings, also exhibits a low species diversity and high dominance value.

Trends in dominance values seem to be indistinct. Samples with high and low dominance values are essentially present over the whole stratigraphic and spatial range (Fig. 20). The only notable pattern is that domi-

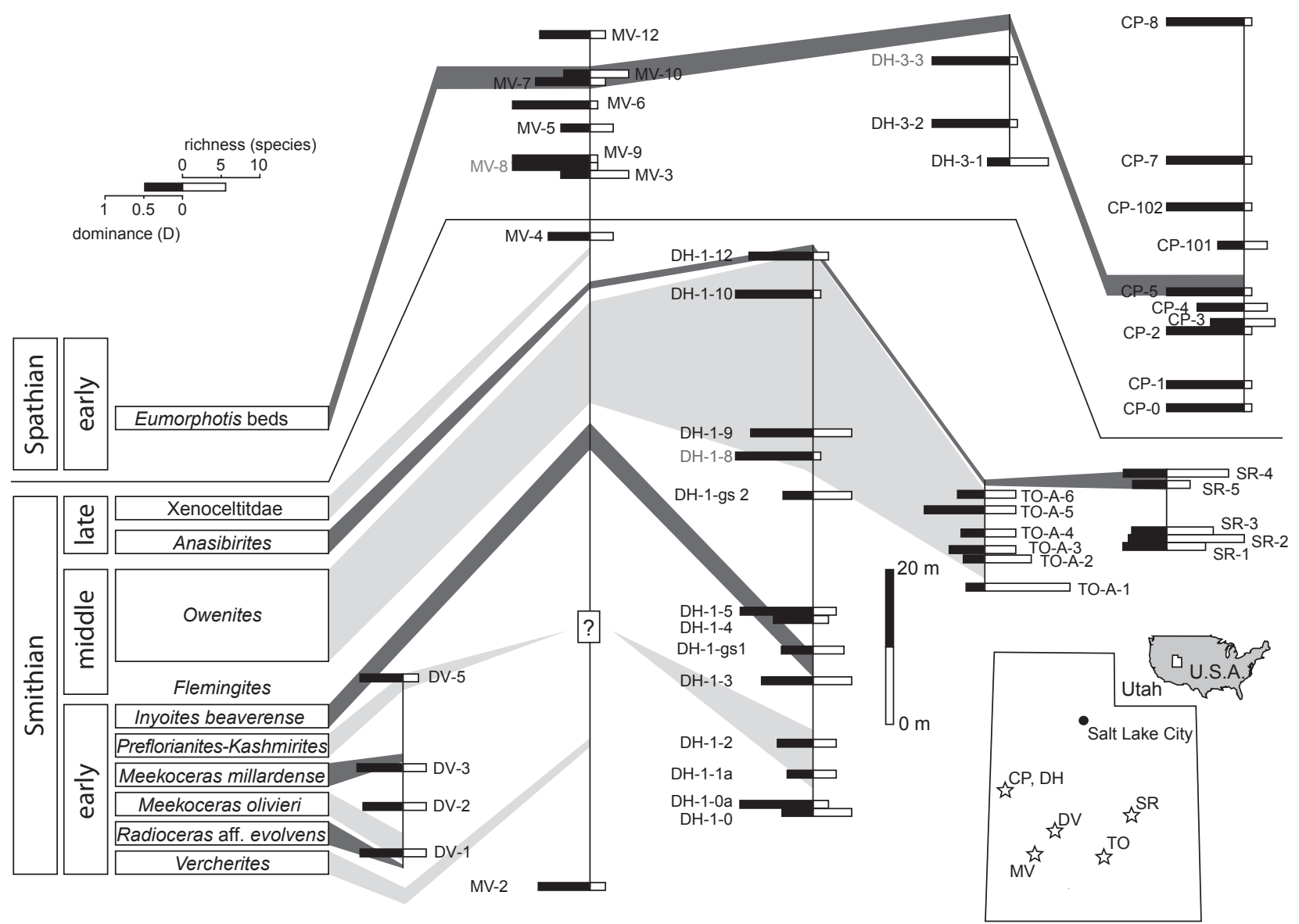

FIG. 20. Stratigraphic distribution of individual sample diversity (species richness) and dominance (Simpson $D)$ in the study area; stratigraphic correlations are based on ammonoids. 
nance increases in lowermost Spathian samples when compared to samples from the Smithian (Fig. 20).

\section{DISCUSSION}

Earlier studies (Schubert and Bottjer 1995) suggested that recovery in benthic ecosystems did not start before the last stage of the Early Triassic (Twitchett and Wignall 1996) and that full recovery did not occur before the Middle Triassic (Schubert and Bottjer 1995). However, there is now a growing body of evidence for at least incipient benthic recovery during the Early Triassic (Krystyn et al. 2003; Shigeta et al. 2009; Kaim et al. 2010; Brayard et al. 2011; Hautmann et al. 2011, 2013; Hofmann et al. 2011). In combination with previous studies on the Early Triassic of the western USA (Hofmann et al. 2013a, $b$ ), new data presented herein enable a comprehensive reevaluation of the benthic recovery at the eastern margin of the tropical Panthalassa ocean. We outline and discuss below these data with respect to possible controls by intrinsic and extrinsic factors.

\section{The early aftermath of the end-Permian mass extinction}

Hofmann et al. (2013a) documented relatively diverse communities around the Griesbachian-Dienerian boundary in shallow marine habitats of the Dinwoody Formation, in accordance with observations of the same time interval in other regions such as Far East Russia (Shigeta et al. 2009), western (Krystyn et al. 2003; Hofmann et al. 2011) and eastern Tethys (Hautmann et al. 2011). This observation implies a relatively fast recovery during the Griesbachian, given the low richness and high dominance of faunas from the early Griesbachian. Communities of outer shelf settings have a poor record in the Dinwoody Formation and, where present, are mostly low in richness and high in dominance. This pattern could reflect harsh environmental conditions such as oxygen deficiency (Wignall and Hallam 1992) in the more distal settings or alternatively an onshore-offshore trend, with higher richness in more proximal settings (Jablonski et al. 1983; Miller 1988; Bottjer et al. 1996), poor preservation and record or a combination of each of these factors.

\section{A Dienerian crisis?}

The upper part of the Dinwoody Formation is poorly constrained in terms of biostratigraphy. The presence of the bivalve species Claraia mulleri and Claraia stachei, which were recently correlated with ammonoid data (Ware et al. 2011), suggests an age close to the Griesbachian-Dienerian boundary. Strata above this interval remain biostratigraphically unresolved, and the biostratigraphic context of the probable diachronous retreat of marine sedimentation in the Dinwoody basin is virtually unknown. Despite these uncertainties, strata above the last occurrence of $C$. mulleri and thus of a Dienerian age show a significant decline back to simple benthic communities in the Gros Ventre Canyon section (Hofmann et al. 2013a). Data from Far East Russia (Shigeta et al. 2009) show the same trend with the highest benthic diversity observed in the upper Griesbachian and the lower Dienerian and a subsequent drop before a new diversification at the base of the Smithian. The significance of this signal in the western USA is unknown, but an overall review of species ranges in the Early Triassic of the western USA indicates a notable turnover between postGriesbachian and pre-Smithian strata in the western USA, with 13 of 19 species disappearing (Fig. 21). Four of these species became extinct on a global scale.

Some support for deleterious environmental conditions during the Dienerian is provided by environmental data. Ware et al. (2011) showed that anoxic conditions in open oceanic settings of eastern Panthalassa were confined to the Dienerian. The same environmental signal has been shown by means of geochemistry for mid-latitude settings of eastern Panthalassa (Grasby et al. 2012). Palynofacies analysis confirms oxygen-restricted conditions for equatorial Tethyan successions of the Salt Range (Hermann et al. 2011). A further hint of at least local environmental deterioration is indicated by the proliferation of the disaster brachiopod genus Lingularia, which may be locally abundant in stressed habitats or becomes widespread in normal marine habitats by expanding into vacant ecospace after large defaunation events (Rodland and Bottjer 2001). Although Lingularia occurs throughout the Dinwoody Formation, it clearly dominates in the immediate aftermath of the extinction, but retreats in younger communities (Hofmann et al. $2013 a$ ), with the exception of a short resurgence in the early Smithian of the study area. In all but these two time intervals of the Early Triassic, Lingula is absent or very rare in the western USA. This pattern seems to support the hypothesis that environmental conditions deteriorated during or before the lowermost Smithian.

In summary, a comparison between the Dinwoody Formation and the Thaynes Group in combination with data from other regions suggests that the Dienerian was likely a time of crisis for benthic communities, although direct information is absent due to the lack of marine strata in the western USA.

\section{The Smithian}

Data presented in this paper show that faunas were ecologically and taxonomically relatively stable throughout 


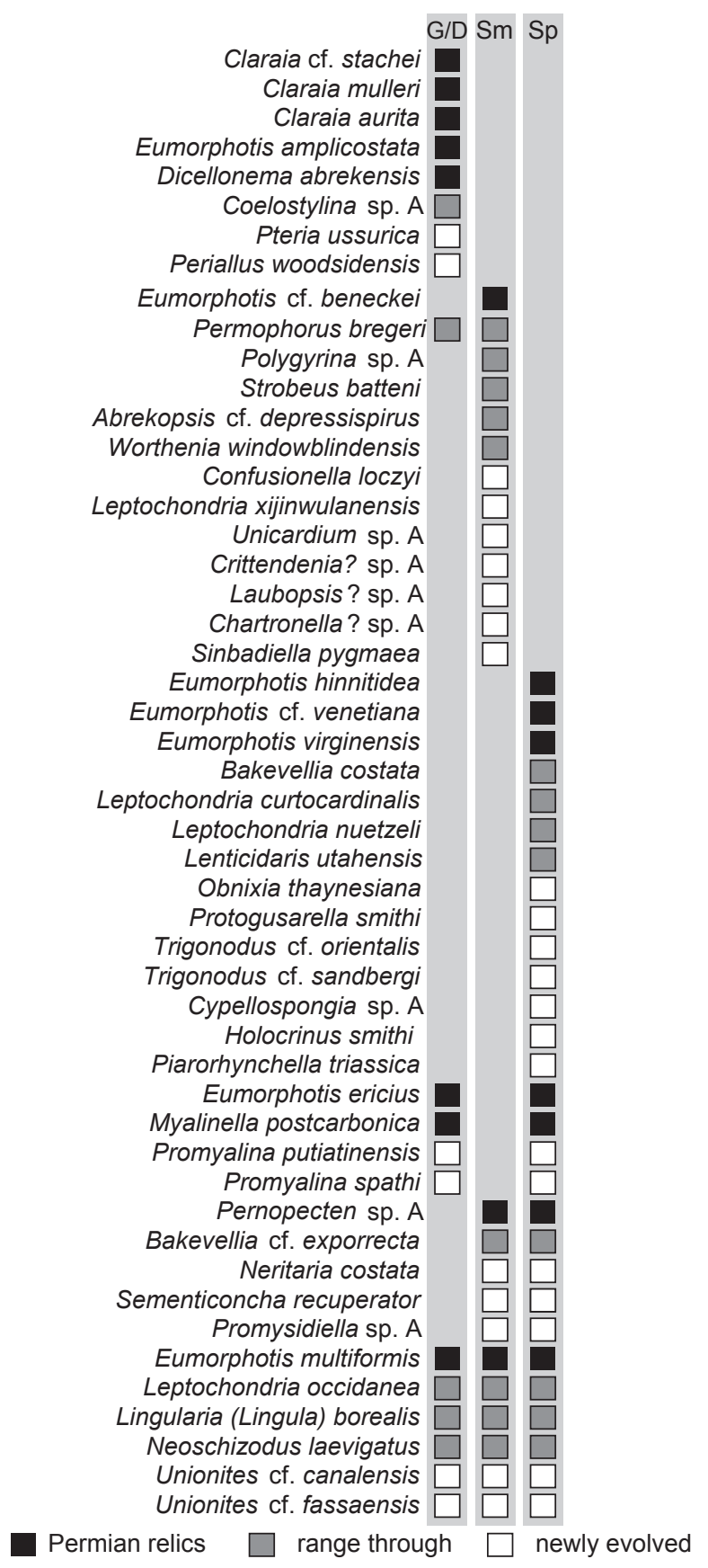

FIG. 21. Stratigraphic range of species reported by Hofmann et al. $(2013 a, b)$ and this work. G/D, Griesbachian-Dienerian; $\mathrm{Sm}$, Smithian; Sp, Spathian. Grey scale code refers to evolutionary fate of respective genera.

the Smithian substage. Correlation of the benthic associations with the ammonoid zonation (Figs 19, 20) indicates that variations in diversity, dominance, ecological and taxonomic composition are independent of their chronostratigraphic context. The only discernible trend is observed in the spatial distribution of communities. More diverse and balanced assemblages are confined to inner and mid-shelf habitats of the Sinbad Formation. Accordingly, an onshore-offshore diversity trend, which is already seen in the Dinwoody Formation (Hofmann et al. $2013 a$ ), continues in the Thaynes Group and the Sinbad Formation. The mean alpha-diversity as well as overall diversity of the Smithian associations is higher than in the Griesbachian and the Dienerian. The stratigraphic range of species (Fig. 21) shows that this rise is related to the establishment of species (18 of 24) that were not recorded in the Dinwoody Formation. It is unlikely that all of these species evolved in the course of Smithian in this area. We therefore assume that the transgression during the early Smithian produced a more open marine shelf setting in comparison with the Dinwoody Formation, which promoted immigration of species, as previously suggested by Schubert and Bottjer (1995). This observation is further supported by the fact that ammonoids were virtually absent in the study area until the Smithian.

The late Smithian witnessed a dramatic and global decline in ammonoid diversity, which is also well documented in rocks in the western USA (Brayard et al. 2009). Romano et al. (2013) recently demonstrated that this crisis is associated with large-scale fluctuations in the oxygen isotope record, which indicates dramatic climatic change across the Smithian substage. These fluctuations ranged from presumably temperate conditions during the early Smithian, hot conditions during the middle Smithian and dramatic cooling during the late Smithian. Evidence for a benthic crisis is scarce. On a global scale, bellerophontoid gastropods became virtually extinct during the Smithian. They were diverse and globally distributed in Lower Triassic formations prior to the Spathian (Kaim and Nützel 2011). Only one younger occurrence of the bellerophontoid Dicellonema is reported from the Anisian of Tibet (Yü 1975), but remains controversial (see Kaim et al. 2013 for discussion). However, in the data from the Thaynes Group, there is no indication that the nekton crisis had an equivalent in benthic ecosystems. Samples from the ammonoid extinction interval (i.e. the Anasibirites Zone) are not notably different in taxonomic composition, ecological structure, diversity or dominance (Fig. 20). To test whether benthic ecosystems suffered from any type of stress during the terminal Smithian, a comparison with samples from the Spathian is necessary.

\section{A Smithian-Spathian boundary event?}

Examined strata occur notably below the oldest Spathian ammonoid zone recognized by Guex et al. (2010) and above the youngest Smithian ammonoid zone. As noted 
earlier, this time interval documents a remarkable shift in the composition of dominant species in benthic faunas of the western USA. Fine-grained intervals typically host the Bakevellia cf. exporrecta association, while bioclastic limestones record the E. ericius association. This signal is accompanied by a drop in diversity and a rise in dominance of faunas (Fig. 20), possibly resulting from transient environmental changes. This shift is significant (Mann-Whitney $U$-test p-values $<0.05$, performed with PAST and R) for the diversities from all Smithian and all Spathian samples, even if more diverse samples from the Sinbad Formation are excluded from the data set. The same is true for the dominance values, but not if the samples of the Sinbad Formation are excluded $(\mathrm{p}=0.11)$.

The bloom of the E. ericius association is observed in all sections described. We herein refer to this bloom as the 'Eumorphotis bioevent', which may be of stratigraphic value for intrabasinal correlations. In contrast to the Dienerian-Smithian transition, there is however, no genus that actually went extinct at the Smithian-Spathian boundary. The shift in taxonomic composition of the benthic associations is not predominantly generated by the origination or immigration of new taxa, but by the increasing abundance of previously rare species. The majority of species that apparently disappeared in the lowermost Spathian belong to newly evolved or rangethrough lineages that have a rich record later in the Triassic. Despite high dominance values and reduced species richness, there is thus no evidence for extinction of benthic taxa during this time interval.

\section{The Spathian}

Data from the late early Spathian Virgin Formation indicate that richness and ecological diversity of benthic faunas significantly increased in comparison with the Smithian. This is reflected by the high alpha-diversity, high guild diversity and the generally more diverse ecological spectrum (Hofmann et al. 2013b) as well as by the high overall diversity (Hautmann et al. 2013). In terms of diversity and guild structure, the Virgin Fauna is actually more similar to Anisian benthic faunas than to any preSpathian fauna (McGowan et al. 2009; Hofmann et al. 2013b). Contrary to previous reports (Pruss and Bottjer 2004; Mata and Bottjer 2011), recent geochemical and palaeoecological data (Marenco et al. 2012) suggest that the strata of the Virgin Formation did not accumulate under oxygen-restricted conditions. This view is well supported by the faunal analysis of Hofmann et al. (2013b). The base of the Spathian, which has been sampled in the Thaynes Group only (this study), is taxonomically and ecologically less diverse than the benthic communities of the Virgin Formation. This difference may be partly due to more advanced recovery in the slightly younger Virgin Formation, but it also appears possible that the main cause is an onshore-offshore trend with higher diversities occurring more proximally (i.e. in the Virgin Formation), as already observed in the Griesbachian-Dienerian and Smithian. In addition, there are fewer samples from the Spathian Thaynes Group than from the Virgin Formation, which possibly adds a bias when data are directly compared. A preliminary comparison with data from the western tropical Tethys (Hofmann et al. $2013 b$ and references therein) suggests a significant interregional early Spathian recovery pulse.

\section{Patterns in alpha- and beta-diversity}

Eurytopicity has frequently been cited as a typical trait of Early Triassic faunas (Schubert and Bottjer 1995) and was usually interpreted as evidence for ongoing environmental stress (Boyer et al. 2004; Pruss and Bottjer 2004; Mata and Bottjer 2011). An alternative explanation has been proposed by Hofmann et al. (2013a, b), who suggested that reduced competition after the end-Permian mass extinction allowed species to exploit virtually the full range of their fundamental niches until competition exceeded a certain threshold. Accordingly, the prediction was made that an increase in within-habitat diversity (alpha-diversity) precedes an increase in between-habitat diversity (beta-diversity) during rediversifications from mass extinction events (Fig. 22A). This explanation accounts for the conflicting observations of (1) a relatively advanced ecological recovery and high within-habitat diversity (alpha-diversity) contrasted by (2) the eurytopic character of most species, expressed in ongoing low beta-diversity.

Assuming that the contribution of beta-diversity to global biodiversity is higher than the contribution of alpha-diversity (Holland 2010), this model may also account for the accelerated increase in interregional diversity in post-Early Triassic times (rebound sensu Sepkoski 1998). The underlying rationale is that the major increase in diversity occurs when competition fosters speciation events by differential adaption of species along environmental gradients, thereby increasing betadiversity.

Our data from the Lower Triassic of the western USA allow the predictions of the model for the first recovery phase to be tested. This is documented in three consecutive time slices: the Griesbachian - ?lower Dienerian of the Dinwoody Formation (Hofmann et al. 2013a), the Smithian Thaynes Group (this paper) and the Spathian part of the Thaynes Group (this paper) together with the late early Spathian Virgin Formation (Hofmann et al. 2013b). These 
A

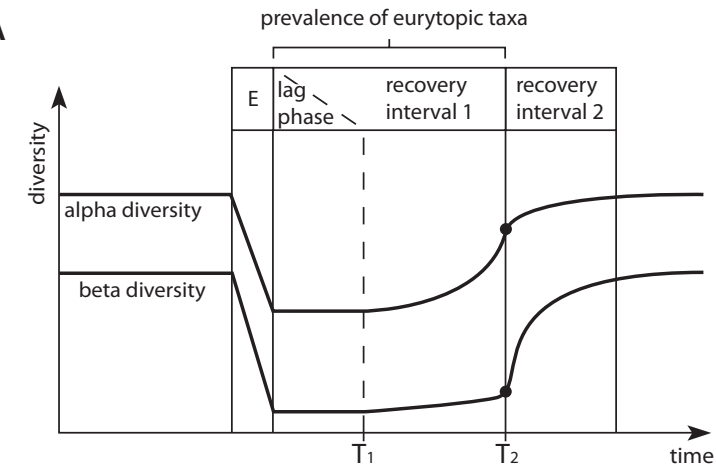

B

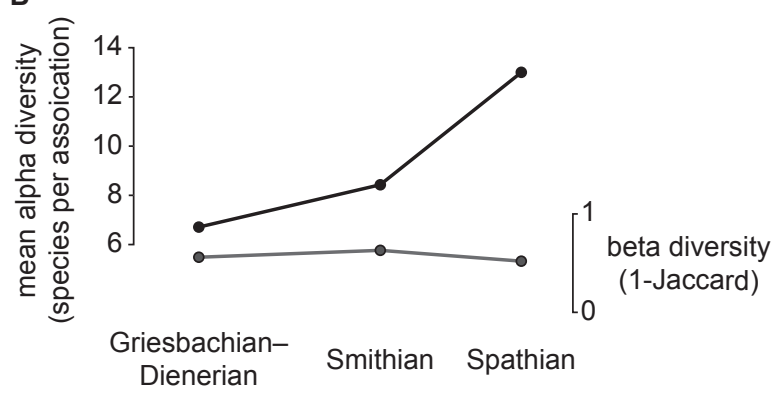

FIG. 22. A, generalized model (after Hofmann et al. 2013b) illustrating the role of habitat saturation in recovery processes. The drop in alpha-diversity during the course of an extinction (E) leads to a corresponding loss of beta-diversity and highly reduced competition among species. A lag phase marks a time interval in which no significant radiation and increase in alphadiversity are observed (Erwin 2001). After initial diversification (T1, start of recovery interval 1), competition within habitats increases following the recovering alpha-diversity. Beta-diversity remains low throughout this interval because adding new species does not result in significant competition for resources. Eventually, alpha-diversity reaches a threshold value where a critical number of species compete for the same, limited resources. The time when this habitat saturation is reached is herein referred to as T2. From this time onward (recovery interval 2), species are increasingly restricted to particular niches because of competitive exclusion from neighbouring habitats. Recovery interval 2 ends when all curves level off. Logistic growth of alpha-diversity is adopted from Erwin (2001). B, test of the model based on own field data. Data for the Griesbachian-Dienerian are from the Dinwoody Formation (Hofmann et al. 2013a). Data for the Smithian are from the Sinbad Formation and the Smithian part of the Thaynes Group (this study). Data for the Spathian are from the Virgin Formation (Hofmann et al. 2013b).

data confirm the model prediction that alpha-diversity increases during the first phase, whereas beta-diversity remains stable (Fig. 22B). The somewhat lower beta-diversity of the Virgin Limestone is most likely due to the much shorter time interval and smaller outcrop area of the Spathian samples. Further work is necessary to confirm: (1) whether the post-Early Triassic diversification of marine invertebrates is associated with an increase in beta-diversity, whereas average alpha-diversity remained stable; and (2) whether the postrecovery level of betadiversity is comparable to pre-extinction times.

\section{CONCLUSIONS}

In addition to the description of the benthic palaeoecology of the Thaynes Group and the Sinbad Formation of the western USA, we have presented a revised interpretation of the recovery from the end-Permian mass extinction at the tropical eastern Panthalassa margin. The succession of faunas and palaeoecological parameters suggests that benthic ecosystems probably suffered from environmental perturbations during parts of the Dienerian, but not from long-lasting deleterious conditions during the entire Early Triassic. The late Smithian-Spathian transition might have been another time of environmental stress, which however had no long-term effect on benthic ecosystems. Notable restoration signals are recorded in shallow shelf settings during the late Griesbachian to early Dienerian, the Smithian and the early Spathian. Diversity of outer shelf communities remains rather low throughout the studied time interval. We interpret this to represent a general proximal-distal trend that reflects an evolutionary delay of rediversification in distal settings compared with more proximal settings where evolutionary innovations are concentrated (cf. Jablonski et al. 1983; Miller 1988). The wide environmental range of taxa probably relates to a nonactualistic low degree of competition in Early Triassic ecosystems. We conclude that the Early Triassic recovery pattern of benthic ecosystems was largely driven by intrinsic dynamics of low-competition ecosystems and short-lived environmental perturbations.

Acknowledgements. This work was supported by the Swiss National Science Foundation project 200020_140350/1 (to $\mathrm{MH})$, the Région Bourgogne and the CNRS INSU Interrvie $(\mathrm{AB}, \mathrm{NO}, \mathrm{EV})$. AN received financial support from the Deutsche Forschungsgemeinschaft (NU 96/6-1, 6-1). All fossil localities mentioned in this report are located on US public land under the stewardship of the Bureau of Land Management (BLM) of the US Department of the Interior and the US Forest Service (Fishlake National Forest) of the US Department of Agriculture; their management and access to these lands are much appreciated. Valuable suggestions by Matthew Clapham (University of California, Santa Cruz) and an anonymous reviewer are gratefully acknowledged. Gilles Escarguel (Universite de Lyon) and Martin Wasmer (Zürich) are thanked for their field assistance. This is a contribution to the IGCP 572.

Editor. George Sevastopulo 


\section{DATA ARCHIVING STATEMENT}

Data for this study are available in the Dryad Digital Repository: http://dx.doi.org/10.5061/dryad.mp40j

\section{SUPPORTING INFORMATION}

Additional Supporting Information may be found in the online version of this article:

Appendix S1. Faunas

Appendix S2. Associations

Appendix S3. Diversity USA

\section{REFERENCES}

ABERHAN, M. 1992. Palökologie und zeitliche Verbreitung benthischer Faunengemeinschaften im Unterjura von Chile. Beringeria, 5, 1-174.

- 1994. Guild-structure and evolution of Mesozoic benthic shelf communities. Palaios, 9, 516-545.

ADAMS, H. and ADAMS, A. 1856. The genera of recent Mollusca arranged according to their organization, 2. Bivalvia. John van Voorst, London, $661 \mathrm{pp}$.

AllasinaZ, A. 1972. Revisione dei Pettinidi Triassici. Rivista Italiana di Paleontologia e Stratigrafia, 78, 189-428.

AMALIZKY, W. 1892. Ueber die Anthracosien der Permformation Russlands. Palaeontographica, 39, 125-213.

B AMB ACH, R. K. 1977. Species richness in marine benthic habitats through the Phanerozoic. Paleobiology, 3, 152-167.

BANDEL, K. 1993. Caenogastropoda during Mesozoic times. Scripta Geologica, Special Issue, 2, 7-56.

- 2007. Description and classification of Late Triassic Neritimorpha (Gastropoda, Mollusca) from the St Cassian Formation, Italian Alps. Bulletin of Geosciences, 82, 215-274.

BATTEN, R. L. and STOKES, W. L. 1986. Early Triassic gastropods from the Sinbad Member of the Moenkopi Formation, San Rafael Swell, Utah. American Museum Novitates, 2864, 1-33.

BEGG, J. G. and CAMPBELL, H. J. 1985. Etalia, a new Middle Triassic (Anisian) bivalve from New Zealand, and its relationship with other pteriomorphs. New Zealand Journal of Geology and Geophysics, 28, 725-741.

BEURLEN, K. 1944. Beiträge zur Stammesgeschichte der Muscheln. Sitzungsberichte der Mathematisch-Naturwissenschaftlichen Abteilung der Bayerischen Akademie der Wissenschaften zu München, 1, 133-145.

— 1954. As faunas de lamellibranquios do sistema genduanico no Parana. 107-136. In LANGE, F. W. (ed.). Paleontologia do Parana. Comissao de Comemoracoes do Centenario do Parana, Curitiba, 210 pp.

BIERNAT, G. and EMIG, C. C. 1993. Anatomical distinctions of the Mesozoic brachiopods. Acta Palaeontologica Polonica, 38, 1-20.

BITTNER, A. 1891. Triaspetrefakten von Balia in Kleinasien. Jahrbuch der Kaiserlich-Königlichen Geologischen Reichsanstalt, 41, 97-116.
1898. Beiträge zur Paläontologie, insbesondere der triadischen Ablagerungen centralasiatischer Hochgebirge. Jahrbuch der Kaiserlich-Königlichen Geologischen Reichsanstalt, 48, 689-718.

_ 1899. Trias-Ablagerungen des Süd-Ussuri-Gebietes in der ostsibirischen Küstenprovinz. Mémoires du Comité Géologique, 7, 1-35.

- 1901a. Ueber Pseudomonotis Telleri und verwandte Arten der unteren Trias. Jahrbuch der Kaiserlich-Königlichen Geologischen Reichsanstalt, 50, 559-592.

— 1901b. Lamellibranchiaten aus der Trias des Bakonyer Waldes, Abhandlung 3. 1-107. In HÖLZEL, E. (ed.). Resultate der wissenschaftlichen Erforschung des Balatonsees, Band 1, Teil 1, Anhang: Palaeontologie der Umgebung des Balatonsees, Band 2. Balaton-Ausschuss der Ungarischen Geographischen Gesellschaft, Wien, 107 pp.

BLAKEY, R. C. 1974. Stratigraphic and depositional analysis of the Moenkopi Formation, southeastern Utah. Utah Geological and Mineral Survey, Bulletin, 104, $81 \mathrm{pp.}$

2012. Global Paleogeography. http://www2.nau.edu/rcb7/ globaltext2.html (accessed May 2012).

BOTTJER, D. J., SCHUBERT, J. K. and DROSER, M. L. 1996. Comparative evolutionary palaeoecology: assessing the changing ecology of the past. Geological Society, London, Special Publications, 102, 1-13.

BOYER, D. L., BOTTJER, D. J. and DROSER, M. L. 2004. Ecological signature of Lower Triassic shell beds of the western United States. Palaios, 19, 372-380.

BRAYARD, A., ESCARGUEL, G., BUCHER, H., HOFMANN, R., GOUDEMAND, N. and GUEX, J. 2009. Good genes and good luck: ammonoid diversity and the endPermian mass extinction. Science, 325, 1118-1121.

— NÜTZEL, A., STEPHEN, D. A., BYLUND, K. G., JENKS, J. and BUCHER, H. 2010. Gastropod evidence against the early Triassic Lilliput effect. Geology, 38, 147150.

— VENNIN, E., OLIVIER, N., BYLUND, K. G., JENKS, J., STEPHEN, D. A., BUCHER, H., HOFMANN, R., GOUDEMAND, N. and ESCARGUEL, G. 2011. Transient metazoan reefs in the aftermath of the end-Permian mass extinction. Nature Geoscience, 4, 693-697.

- BYLUND, K. G., JENKS, J. F., STEPHEN, D. A., OLIVIER, N., ESCARGUEL, G., FARA, E. and VENNIN, E. 2013. Smithian ammonoid faunas from Utah: implications for Early Triassic biostratigraphy, correlation and basinal paleogeography. Swiss Journal of Palaeontology. doi: 10. 1007/s13358-013-0058-y, published online 30 August 2013.

BROGLIO LORIGA, C. and MIRABELLA, S. 1986. Il genere Eumorphotis Bittner 1901 nella biostratigrafia dello Scitico, Formazione di Werfen (Dolomiti). Memorie di Scienze Geologiche, 38, 245-274.

BRONN, H. G. 1849. Index Palaeontologicus oder Übersicht der bis jetzt bekannten fossilen Organismen. Zweite Abtheilung. Enumerator palaeontologicus: systematische Zusammenstellung und geologische Entwickelungs-Gesetze der organischen Reiche. Schweizerbart, Stuttgart, 776 pp.

CARR, T. R. and PAULL, R. K. 1983, Early Triassic stratigraphy and paleogeography of the Cordilleran miogeocline. 3955. In REYNOLDS, A. and DOLLY, E. D. (eds). Mesozoic 
Paleogeography of the West-Central United States. SEPM, Denver, CO, $391 \mathrm{pp}$.

CARTER, J. G. and HAUTMANN, M. 2011. Shell microstructure of the basal pectinid Pleuronectites laevigatus: implications for pectinoid phylogeny (Mollusca: Bivalvia: Pteriomorphia). Journal of Paleontology, 85, 464-467.

CATUlLO, T. A. 1846. Memoria geognostico-paleozoica sulle Alpi Venete. Memorie della Società Italiana delle Scienze Residente in Modena, 24, 1-158.

CAVAROC, V. V. and FLORES, R. M. 1991. Red beds of the Triassic Chugwater Group, Southwestern Powder River Basin, Wyoming. U.S. Geological Survey Bulletin, 1917-E, 17 p.

CHAVAN, A. 1954. Les Pleurophorus et genres voisins. Cahiers Géologiques Seyssel, 22, 200.

CIRIACKS, K. W. 1963. Permian and Eotriassic bivalves of the Middle Rockies. Bulletin of the American Museum of Natural History, 125, 1-100.

CLARK, D. L. and CARR, T. R. 1984. Conodont biofacies and biostratigraphic schemes in western North America: a model. Geological Society of America Special Paper, 196, $1-9$.

COLlinsON, J. W. and HASENMUElleR, W. A. 1978. Early Triassic paleogeography and biostratigraphy of the Cordilleran miogeosyncline. In HOWELL, D. G. and McDOUGALL, K. A. (eds). Mesozoic paleogeography of the western United States. Society of Economic Paleontologists and Mineralogists, Pacific Section, Pacific Coast Paleogeography Symposium, 2, 175-187.

COSSMANN, M. 1895. Essais de Paléoconchologie Comparée. Première Livraison. M. Cossmann, Comptoir Géologique, Paris, $161 \mathrm{pp}$.

1902. Rectification de nomenclature. Revue Critique de la Nomenclature, 6, $233 \mathrm{pp}$.

1915. Étude complementaire sur le Charmoutien de la Vendée. Mémoires de la Société Linnéenne de Normandie, Section Geologique, 33, 113-159.

COX, L. R. 1929. A synopsis of the Lamellibranchia and Gastropoda of the Portland beds of England. Part 1. Lamellibranchiata. Proceedings of the Dorset Natural History and Archaeological Society, 50, 131-202.

1962. New genera and subgenera of Mesozoic Bivalvia. Palaeontology, 4, 592-598.

1964. Notes concerning the taxonomy and nomenclature of fossil Bivalves (mainly Mesozoic). Proceedings of the Malacological Society of London, 36, 39-48.

— NEWELL, N. D., BOYD, D. W., BRANSON, C. C., CASEY, R., CHAVAN, A., COOGAN, A. H., DECHASEUX, C., FLEMING, C. A., HAAS, F., HERTLEIN, L. G., KAUFFMAN, E. G., KEEN, A. M., LA ROCQUE, A., McAleSTER, A. L., MOORE, R. C., NUTTALL, C. P., PERKINS, B. F., PURI, H. S., SMITH, L. A., SOOT-RYEN, T., STENZEL, H. B., TRUEMAN, E. R., TURNER, R. D. and WEIR, J. 1969. Bivalvia. In MOORE, R. C. (ed.). Treatise on invertebrate paleontology, Part N, Mollusca. 6. Geological Society of America and University of Kansas Press, Boulder, Colorado and Lawrence, Kansas, 1224 pp.
CUVIER, G., 1797-1798. Tableau élémentaire de l'histoire naturelle des animaux. Baudouin, Paris, $710 \mathrm{pp}$.

DALL, W. H. 1899. Pelecypoda. 346-429. In ZITTEL, K. A. and EASTMAN, C. R. VON. (eds). Text-book of Palaeontology. MacMillan \& Co., New York, 520 pp.

DICKINS, J. M. 1957. Lower Permian pelecypods and gastropods from the Carnarvon Basin, Western Australia. Commonwealth of Australia, Department of National Development, Bureau of Mineral Resources, Geology and Geophysics, Bulletin, 41, 1-71.

DIENER, C. 1923. Lamellibranchiata triadica. Fossilium catalogus I: Animalia. Pars 19. W. Junk, Berlin, 257 pp.

DUMERIL, A. M. C. 1806. Zoologie analytique ou méthode naturelle de classification des animaux. Allais, Paris, xxiv, 364 pp.

ERWIN, D. H. 2001. Lessons from the past: biotic recoveries from mass extinctions. Proceedings of the National Academy of Sciences of the United States of America, 98, 5399-5403.

FANG, Z.-J., CHEN, J., CHEN, C., SHA, J., LAN, X. and WEN, S. 2009. Supraspecific taxa of the Bivalvia first named, described, and published in China (1927-2007). The University of Kansas Paleontological Contributions, New Series, 17, 1-157.

FÉRUSSAC, A. E. DE. 1822. Tableaux systématiques des animaux mollusques classés en familles naturelles, dans lesquels on a établi la concordance de tous les systèmes; suivis d'un prodrome général pour tous les mollusques terrestres ou fluviatiles, vivants ou fossiles. Bertrand, Paris, $111 \mathrm{pp}$.

FLEMING, J. 1828. A history of British animals, exhibiting the descriptive characters and systematical arrangement of the genera and species of quadrupeds, birds, reptiles, fishes, Mollusca and Radiata of the United Kingdom; including the indigenous, extirpated, and extinct kinds; together with periodical and occasional visitants. Bell and Bradfute, Edinburgh, xxiii +554 pp.

FRECH, F. 1907. Die Leitfossilien der Wefener Schichten und Nachträge zur Fauna des Muschelkalkes der Cassianer und Raibler Schichten sowie des Rhaet und des Dachsteinhauptdolomites (Hauptdolomit). Resultate der Wissenschaftlichen Erforschung des Balatonsees, Anhang, Palaeontologie der Umgebung des Balatonsees, 1, 1-95.

FÜRSICH, F. T. 1984. Paleoecology of boreal invertebrate faunas from the Upper Jurassic of Central East Greenland. Palaeogeography Palaeoclimatology Palaeoecology, 48, 309-364.

— and WENDT J. 1977. Biostratinomy and palaeoecology of the Cassian formation (Triassic) of the Southern Alps. Palaeogeography, Palaeoclimatology, Palaeoecology, 22, 257-323.

GEINITZ, H. B. 1842. Über einige Petrefakten des Zechsteins und Muschelkalks. Neues Jahrbuch für Mineralogie, 1842, 576579.

GEYER, G., HAUTMANN, M. T., HAgDORN, H., OCKERT, W. and STRENG, M. 2005. Well-preserved molluscs from the Lower Keuper (Ladinian) of Hohenlohe (Southwest Germany). Palaeontologische Zeitschrift, 79, 429460.

GIEBEL, C. 1855. Kritisches über die Myophorien des Muschelkalkes. Zeitschrift für die Gesamten Naturwissenschaften, 5, 34-36. 
GIRTY, G. H. 1927. Descriptions of new species of Carboniferous and Triassic fossils, 434-446. In MANSFIELD, G. R. (ed.). Geography geology and mineral resources of part of southeastern Idaho With descriptions of Carboniferous and Triassic fossils. US Geological Survey Professional Paper, 152, 453 pp.

GOLDFUSS, G. A. 1833-1840. Petrefacta Germaniae. Abbildungen und Beschreibungen der Petrefacten Deutschlands und der angränzenden Länder, unter Mitwirkung des Herrn Grafen Georg zu Münster, herausgegeben von August Goldfuss. Zweiter Teil. Arnz and Co., Düsseldorf, 211 pp.

GOODSPEED, T. H. and LUCAS, S. G. 2007. Stratigraphy, sedimentology, and sequence stratigraphy of the Lower Triassic Sinbad Formation, San Rafael Swell, Utah. New Mexico Museum of Natural History and Science Bulletin, 40, 91-102.

GORYANSKY, V. Y. U. and POPOV, L. E. 1985. Morphology, systematic position and origin of the inarticulate brachiopods with calcareous shells. Paleontologicheskii Zhurnal, 1985, 3-14.

GRASBY, S. E., BEAUCHAMP, B., EMBRY, A. and SANEI, H. 2012. Recurrent Early Triassic ocean anoxia. Geology, 41, 175-178.

GRAY, J. E. 1847. A list of the genera of Recent Mollusca, their synonyms and types. Proceedings of the Zoological Society of London, 15, 129-219.

GROBBEN, C. 1894. Zur Kenntnis der Morphologie, der Verwandtschaftsverhältnisse und des Systems der Mollusken. Sitzungsberichte der Akademie der Wissenschaften Wien, 103, 61-86.

GUEX, J., HUNGERBÜHLER, A., JENKS, J. F., O'Dogherty, L., ATUdorei, V., TAYlor, D. G., BUCHER, H. and BARTOLINI, A. 2010. Spathian (Lower Triassic) ammonoids from western USA (Idaho, California, Utah and Nevada). Mémoires de Géologie Lausanne, 49, $82 \mathrm{pp}+\mathrm{LX} \mathrm{pl}$.

HALLAM, A. 1991. Why was there a delayed radiation after the end-Palaeozoic extinctions? Historical Biology, 5, 257262.

HAMMER, Ø. and HARPER, D. A. T. 2006. Paleontological data analysis. Blackwell Publishers, Malden, MA, x, 351 pp.

— $—$ and RYAN P. D. 2001. Past: paleontological statistics software package for education and data analysis. Palaeontologia Electronica, 4, 1-9.

HAUTMANN, M. 2004. Early Mesozoic evolution of alivincular bivalve ligaments and its implications for the timing of the "Mesozoic marine revolution". Lethaia, 37, 165-172.

— 2008. Taxonomy and phylogeny of the Triassic bivalve families Mysidiellidae Cox, 1964 and Healeyidae new family. Journal of Paleontology, 82, 555-564.

- 2010. The first scallop. Paläontologische Zeitschrift, 84, 317322.

— 2011. Suborder Entoliidina Hautmann, nov.; Family Pleuronectitidae Hautmann, nov.; Family Antijaniridae Hautmann, nov.; Family Ornithopectinidae Hautmann, nov. In CARTER et al. A synoptical classification of the Bivalvia (Mollusca). Paleontological Contributions, 4, 1-47.

— and HAGDORN H. 2013. Oysters and oyster-like bivalves from the Middle Triassic Muschelkalk of the Germanic Basin. Palaeontologische Zeitschrift, 87, 19-32.
- and NÜTZEL A. 2005. First record of a heterodont bivalve (Mollusca) from the Early Triassic: palaeoecological significance and implications for the 'Lazarus problem'. Palaeontology, 48, 1131-1138.

— BUCHER, H., BRÜHWILER, T., GOUDEMAND, N., KAIM, A. and NÜTZEL, A. 2011. An unusually diverse mollusc fauna from the earliest Triassic of South China and its implications for benthic recovery after the end-Permian biotic crisis. Geobios, 44, 71-85.

— SMITH, A. B., MCGOWAN, A. J. and BUCHER, H. 2013. Bivalves from the Olenekian (Early Triassic) of southwestern Utah: systematics and evolutionary significance. Journal of Systematic Palaeontology, 11, 263-293.

HERMANN, E., HOCHUli, P. A., MÉHAY, S., BUCHER, H., BRÜHWILER, T., WARE, D., HAUT MANN, M., ROOHI, G., UR-REHMAN, K. and YASEEN, A. 2011. Organic matter and palaeoenvironmental signals during the Early Triassic biotic recovery: the Salt Range and Surghar Range records. Sedimentary Geology, 234, 19-41.

HERTWIG, C. W. T. R. 1895. Lehrbuch der Zoologie, Third edition. Fischer, Jena, 599 pp.

HOFMANN, R., GOUdEMAND, N., WASMER, M., BUCHER, H. and HAUTMANN, M. 2011. New trace fossil evidence for an early recovery signal in the aftermath of the end-Permian mass extinction. Palaeogeography, Palaeoclimatology, Palaeoecology, 310, 216-226.

- HAUtmanN, M. and BUCHER, H. 2013a. A new paleoecological look at the Dinwoody Formation (Lower Triassic, western US): intrinsic versus extrinsic controls on ecosystem recovery after the end-Permian mass extinction. Journal of Paleontology, 87, 854-880.

- WASMER, M. and BUCHER, H. 2013b. Palaeoecology of the Spathian Virgin Formation (Utah, USA) and its implications for the Early Triassic Recovery. Acta Palaeontologica Polonica, 58, 149-173.

— — BRAYARD, A., NÜTZEL, A., BYLUND, K. G., JENKS, J. F., VENNIN, E., OLIVIER, N. and BUCHER, H. 2013c. Data from: Recovery of benthic marine communities from the end-Permian mass extinction at the low-latitudes of Eastern Panthalassa. Dryad Digital Repository. http://dx.doi.org/10.5061/dryad.mp40j

HOLMER, L. E. and BENGTSON, P. 2009. The first occurrence of a lingulid brachiopod from the Cretaceous of Sergipe, Brazil, with a restudy of 'Lingula' bagualensis Wilckens, 1905 from southern Patagonia. Paläontologische Zeitschrift, 83, 255266.

HOLLAND, S. M. 2010. Additive diversity partitioning in palaeobiology: revisiting Sepkoski's question. Palaeontology, 53, 1237-1254.

HOOVER, P. R. 1979. Early Triassic Terebratulid brachiopods from the western interior of the United States. United States Geological Survey Professional Paper, 1057, 1-21.

ICHIKAWA, K. 1958. Zur Taxionomie und Phylogenie der Triadischen "Pteriidae" (Lamellibranch.). Palaeontographica, Abteilung A, 111, 131-212.

JABLONSKI, D., SEPKOSKI, J. J., BOTTJER, D. J. and SHEEHAN, P. M. 1983. Onshore-offshore patterns in the 
evolution of Phanerozoic shelf communities. Science, 222, $1123-1125$.

KAIM, A. 2009. Gastropods. In SHIGETA, Y., ZAKHAROV, Y. D., MAEDA, H. and POPOV, A. M. (eds). The Lower Triassic system in the Abrek Bay area, south Primorye, Russia. National Museum of Nature and Science Monographs, 38, 141-156.

_ and NÜTZEL A. 2011. Dead bellerophontids walking the short Mesozoic history of the Bellerophontoidea (Gastropoda). Palaeogeography Palaeoclimatology Palaeoecology, 308, 190-199.

BUCHER, H., BRÜHWILER, T. and GOUDEMAND, N. 2010. Early Triassic (Late Griesbachian) gastropods from South China (Shanggan, Guangxi). Swiss Journal of Geosciences, 103, 121-128.

- HAUTMANN, M. and BUCHER, H. 2013. Early Triassic gastropods from Salt Range, Pakistan. Bulletin of Geosciences, 88, 505-516.

KASHIYAMA, Y. and OJI, T. 2004. Low-diversity shallow marine benthic fauna from the Smithian of northeast Japan: paleoecologic and paleobiogeographic implications. Paleontological Research, 8, 199-218.

KING, W. 1848. A catalogue of the organic remains of the Permian rocks of Northumberland and Durham. Published by the author, Newcastle-upon-Tyne, $16 \mathrm{pp}$.

- 1850. A monograph of the Permian Fossils of England. Palaeontographical Society, London, $258 \mathrm{pp}$.

KIPARISOVA, L. D. 1938. Nizhnetriasovye plastinchatozhabernye Ussurijskogo kraya. Trudy Geologicheskogo Instituta, 7, 197-311. [In Russian].

KITTL, E. 1904. Geologie der Umgebung von Sarajevo. Jahrbuch der Kaiserlich-Königlichen Geologischen Reichsanstalt, 53 [for 1903], 707-738.

KNIGHT, J. B. 1931. The gastropods of the St. Louis, Missouri, Pennsylvanian outlier: the Subulitidae. Journal of Paleontology, 5, 177-229.

KOKEN, E. 1892. Ueber die Gastropoden der rothen Schlernschichten nebst Bemerkungen über Verbreitung und Herkunft einiger triassischer Gattungen. Neues Jahrbuch für Mineralogie, Geologie und Paläontologie, 2, 25-36.

1896. Die Leifossilien, ein Handbuch für den Unterricht und das Bestimmen von Versteinerungen. Chr. Herm. Tauchnitz, Leipzig, $848 \mathrm{pp}$.

KONINCK, L. G. DE. 1881. Faune du calcaire carbonifere de la Belgique, 3e partie, Gastéropodes. Musée Royal d'Histoire Naturelle de Belgique Annales, Série Paléntologique, 6, $1-170$.

1883. Faune du calcaire carbonifére de la Belgique, quartiéme partie. Gastéropodes. Musée Royal d'Histoire Naturelle de Belgique Annales, Série Paléntologique, 8, 1-240.

KOROBKOV, I. A. 1960. Anisomyaria. p. 83. In EBERZIN, A. G. (ed.). Osnovy Paleontologii, Vol. 3. Academy Nauk USSR, Moscow, 300 pp.

KRYSTYN, L., RICHOZ, S., BAUD, A. and TWITCHETT, R. J. 2003. A unique Permian-Triassic boundary section from the Neotethyan Hawasina Basin, Central Oman Mountains. Palaeogeography Palaeoclimatology Palaeoecology, 191, 329-344.
KUMAGAE, T. and NAKAZAWA, K. 2009. Bivalves. 156173. In SHIGETA, Y., ZAKHAROV, Y. D., MAEDA, H. and POPOV, A. M. (eds). The Lower Triassic system in the Abrek Bay area, south Primorye, Russia. National Museum of Nature and Science Monographs, 38, 156-173.

KUMMEL, B. and STEELE, G. 1962. Ammonites from the Meekoceras-Gracilitatus Zone at Crittenden-Spring, Elko County, Nevada. Journal of Paleontology, 36, 638-703.

LEPSIUS, R. 1878. Das westliche Südtirol. Verlag Wilhelm Hertz, Berlin, 375 pp.

LINNAEUS, C. 1758. Systema naturae per regna tria naturae, secundum classes, ordines, genera, species, cum characteribus, differentiis, synonymis, locis. Tomus I. Editio Decima. Laurentius Salvius, Stockholm, $824 \mathrm{pp}$.

LUCAS, S. G., KRAINER, K. and MILNER, A. R. 2007. The type section and age of the Timpoweap Member and stratigraphic nomenclature of the Triassic Moenkopi Group in Southwestern Utah. New Mexico Museum of Natural History and Science Bulletin, 40, 109-117.

MARENCO, P. J., GRIFFIN, J. M., FRAISER, M. L. and CLAPHAM, M. E. 2012. Paleoecology and geochemistry of Early Triassic (Spathian) microbial mounds and implications for anoxia following the end-Permian mass extinction. Geology, 40, 715-718.

MARWICK, J. 1953. Divisions and faunas of the Hokonui system (Triassic and Jurassic). New Zealand Geological Survey, Paleontological Bulletin, 21, 1-141.

MATA, S. A. and BOTTJER, D. J. 2011. Origin of Lower Triassic microbialites in mixed carbonate-siliciclastic successions: ichnology, applied stratigraphy, and the end-Permian mass extinction. Palaeogeography, Palaeoclimatology, Palaeoecology, 300, 158-178.

McGOWAN, A. J., SMith, A. B. and TAYlor, P. D. 2009. Faunal diversity, heterogeneity and body size in the Early Triassic: testing post-extinction paradigms in the Virgin Limestone of Utah, USA. Australian Journal of Earth Sciences, 56, 859-872.

MEEK, F. B. 1877. Part I: Palaeontology. 1-197. In KING, C. (ed.). Annual report to the secretary of war on the U.S. geological exploration of the Fortieth Parallel 4. Government Printing Office, Washington.

— and HAYDEN F. V. 1864. Palaeontology of the Upper Missouri. Smithsonian Contributions to Knowledge, 14, 1135.

MENKE, C. T. 1828, Synopsis methodica molluscorum generum omnium et specierum earum quae in Museo Menkeano adservantur. Pyrmonti sumtibus Georgi Uslar, 91 pp.

MILLER, S. A. 1877. The American Paleozoic fossils: a catalogue of the genera and species. Published by the author, Cincinnati, 334 pp.

MILLER, A. I. 1988. Spatio-temporal transitions in Paleozoic Bivalvia: an analysis of North American fossil assemblages. Historical Biology, 1, 251-273.

MORISITA, M. 1959. Measuring of interspecific association and similarity between communities. Memoirs of the Faculty of Science, Kyushu University Series E (Biology), 3, 65-80.

MÜNSTER, G. GRAF ZU. 1841. Beiträge zur Petrefacten-Kunde. IV. Beschreibung und Abbildung der in den Kalkmergels- 
chichten von St. Cassian gefundenen Versteinerungen. Buchner' sche Buchhandlung, Bayreuth, 152 pp.

NERI, C. and POSENATO, R. 1985. New biostratigraphical data on uppermost Werfen formation of western Dolomites (Trento, Italy). Geologisch-Paläontologische Mitteilungen Innsbruck, 14, 83-107.

NEUMAYR, M. 1884. Zur Morphologie des Bivalvenschlosses. Sitzungsberichte der Akademie der Wissenschaften in Wien, Mathematisch-Naturwissenschaftliche Klasse, Abteilung. 1, 88, 385-418.

NEWELL, N. D. 1938. Late Paleozoic pelecypods: Pectinacea. State Geological Survey of Kansas Publications, 10 [for 1937], 1-123.

- 1965. Classification of the Bivalvia. American Museum Novitates, 2206, 1-25.

— 1969. Order Modiomorphoida Newell, new order. P. N393. In MOORE, R. C. (ed.). Treatise on invertebrate paleontology, Part N, Mollusca 6, Vol. 1. Geological Society of America and University of Kansas Press, Boulder, 489 pp.

- and BOYD D. W. 1995. Pectinoid bivalves of the Permian-Triassic crisis. Bulletin of the American Museum of Natural History, 227, 5-95.

— and KUMMEL B. 1942. Lower Eo-Triassic stratigraphy, western Wyoming and southeast Idaho. Geological Society of America Bulletin, 53, 937-996.

NEYMAN, A. A. 1967. Limits to the application of the trophic group concept in benthic studies. Oceanology, 7, 149-155.

NÜTZEL, A. 2005. A new Early Triassic gastropod genus and the recovery of gastropods from the Permian/Triassic extinction. Acta Palaeontologica Polonica, 50, 19-24.

— and SCHULBERT C. 2005. Facies of two important Early Triassic gastropod Lagerstätten: implications for diversity patterns in the aftermath of the end-Permian mass extinction. Facies, 51, 480-500.

ORBIGNY, A. d'. 1850. Prodrome de paléontologie stratigraphique universelle des animaux mollusques et rayonnés faisant suite au coursélémentaire der paléontologie et géologie stratigraphiques. Deuxième Volume, Masson, Paris, 427 pp.

PAULL, R. A. and PAULL, R. K. 1993. Interpretation of Early Triassic nonmarine-marine relations, Utah, USA. New Mexico Museum of Natural History and Science Bulletin, 3, 403-409.

PENG, Y. Q. and SHI, G. R. 2008. New Early Triassic Lingulidae (Brachiopoda) genera and species from South China. Alcheringa, 32, 149-170.

PERRY, D. G. and CHATTERTON, B. D. E. 1979. Late Early Triassic brachiopod and conodont fauna, Thaynes Formation, Southeastern Idaho. Journal of Paleontology, 53, 307-319.

POBORSKY, S. J. 1954. Virgin formation (Triassic) of the St. George, Utah, area. Bulletin of the Geological Society of America, 65, 971-1006.

POSENATO, R. 2008. Anisian (Middle Triassic) bivalves from the Dolomites (Italy). Neues Jahrbuch fur Geologie und Palaontologie-Abhandlungen, 247, 93-115.

— PELIKAN, P. and HIPS, K. 2005. Bivalves and brachiopods near the Permian-Triassic boundary from the Bukk Mountains (Balvany-North section, Northern Hungary). Rivista Italiana di Paleontologia e Stratigrafia, 111, 215-232.
PRUSS, S. B. and BOTTJER, D. J. 2004. Early Triassic trace fossils of the western United States and their implications for prolonged environmental stress from the end-Permian mass extinction. Palaios, 19, 551-564.

RAFINESQUE, C. S. 1815. Analyse de la nature ou tableau de l'a Univers et des corps organisés. Jean Barravecchia, Palermo, 224 pp.

RICHTHOFEN, F. VON. 1860. Geognostische Beschreibung der Umgebung von Predazzo. Sanct Cassian und der Seiser Alpe in Süd-Tyrol, Gotha (Perthes), $327 \mathrm{pp}$.

RODLAND, D. L. and BOTTJER, D. J. 2001. Biotic recovery from the end-permian mass extinction: behavior of the inarticulate brachiopod Lingula as a disaster taxon. Palaios, 16, 95-101.

ROMANO, C., GOUDEMAND, N., VENNEMANN, T. W., WARE, D., SCHNEEBELI-HERMANN, E., HOCHULI, P. A., BRUHWILER, T., BRINKMANN, W. and BUCHER, H. 2013. Climatic and biotic upheavals following the end-Permian mass extinction. Nature Geoscience, 6, 57-60.

SALVINI-PLAWEN, L. V. 1980. A reconsideration of systematics in the Mollusca (phylogeny and higher classification). Malacologica, 19, 249-278.

SCHAUROTH, K. VON. 1859. Kritisches Verzeichnis der Versteinerungen der Trias im Vicentinischen. Sitzungsberichte der Kaiserlichen Akademie der Wissenschaften Wien, Mathematisch-Naturwissenschaftliche Classe, 34, 283-356.

SCHUBERT, J. K. and BOTTJER, D. J. 1995. Aftermath of the Permian-Triassic mass extinction event: paleoecology of Lower Triassic carbonates in the western USA. Palaeogeography, Palaeoclimatology, Palaeoecology, 116, 1-39.

SCHWARDT, A. 1992. Revision der Wortheniella Gruppe (Archaeogastropoda) der Cassianer Schichten (Trias, Dolomiten). Annalen des Naturhistorischen Museums in Wien, 94, 23-57.

SEPKOSKI, J. J. 1988. Alpha, beta, or gamma - where does all the diversity go. Paleobiology, 14, 221-234.

_ and MILLER A. I. 1998. Analysing diversification through time. Trends in Ecology \& Evolution, 13, 158-159.

SHA, J. 1995. Bivalves. 82-116, 151-153. In SHA, J. (ed.). Palaeontology of Hoh Xil region, Qinghai. Science Press, Beijing, China, 177 pp, 50 pls. [In Chinese with English abstract].

— and GRANT-MACKIE J. A. 1996. Late Permian to Miocene bivalve assemblages from Hohxil, Qinghai-Xizang Plateau, China. Journal of the Royal Society of New Zealand, 26, 429-455.

ShigeTA, Y., ZAKAHAROV, Y. D., MAEDA, H. and POPOV, A. M. (eds) 2009. The Lower Triassic System in the Abrek Bay area, south Primorye, Russia. National Museum of Nature and Science Monographs, Vol. 38. Tokyo, 218 pp.

STANLEY, M. S. 1972. Functional morphology and evolution of byssally attached bivalve mollusks. Journal of Paleontology, 46, 165-212.

STEHLI, F. G. 1965, Paleozoic Terebratulida. H730-H762. In MOORE, R. C. (ed.). Treatise on invertebrate paleontology, Part H, Brachiopoda, Vol. 2. Geological Socity of America and Univercity of Kansas Press, New York and Lawrence, Kansas, 404 pp. 
STEPHEN, D. A., BYLUND, K., BYBEE, P. J. and REAM, W. J. 2010. Ammonoid beds in the Lower Triassic Thaynes Formation of western Utah, USA. 243-252. In TANABE, K., SHIGETA, Y., SASAKI, T. and HIRANO, H. (eds). Cephalopods - present and past. Tokai University Press, Tokyo, 314 pp.

STOLICZKA, F. 1870-1871. Cretaceous fauna of southern India. 3. The Pelecypoda, with a review of all known genera of this class, fossil and Recent. Geological Survey of India, Palaeontologica Indica Memoirs, 6, 1-537.

THOMSON, J. A. 1926. A revision of the subfamilies of the Terebratulidae (Brachiopoda). The Annals and Magazine of Natural History, Series 9, 18, 523-530.

TWITCHETT, R. J. and WIGNALL, P. B. 1996. Trace fossils and the aftermath of the Permo-Triassic mass extinction: evidence from northern Italy. Palaeogeography, Palaeoclimatology, Palaeoecology, 124, 137-151.

VOKES, H. E. 1967. Genera of the Bivalvia: a systematic and bibliographic catalogue. Bulletins of American Paleontology, 51, 105-394.

WAAGEN, W. 1883. Productus Limestone fossils, Part IV, fas. 2. Salt Range Fossils. Palaeontologia Indica, Series, 13, 391-546.

1895. Salt-Range fossils, Vol. 2: fossils from the Ceratite Formation. Pisces-Ammonoidea (Cephalopoda). Memoirs of the Geological Survey of India, Palaeontologia Indica, 13, 1-323.

WALLER, T. R. 1978. Morphology, morphoclines and a new classification of the Pteriomorphia (Mollusca: Bivalvia). Philosophical Transactions of the Royal Society of London, Series B, 284, 345-365.

— 2005. Systematic Palaeontology. 7-50. In WALLER, T. R. and STANLEY, G. D. 2005. Middle Triassic pteriomorphian bivalvia (Mollusca) from the New Pass Range, west-central Nevada: systematics, biostratigraphy, paleoecology, and paleobiogeography. Journal of Paleontology, 79, 1-58.

- 2006. Phylogeny of families in the Pectinoidea (Mollusca: Bivalvia): importance of the fossil record. Zoological Journal of the Linnean Society, 148, 313-342.

_ and STANLEY G. D. 2005. Middle Triassic pteriomorphian bivalvia (Mollusca) from the New Pass Range, west-central Nevada: systematics, biostratigraphy, paleoecology, and paleobiogeography. Journal of Paleontology, 79, 1-58.

WARE, D., JENKS, J. F., HAUTMANN, M. and BUCHER, H. 2011. Dienerian (Early Triassic) ammonoids from the Candelaria Hills (Nevada, USA) and their significance for palaeobiogeography and palaeoceanography. Swiss Journal of Geosciences, 104, 161-181.

WASMER, M. and HAUTMANN, M. 2012. Systematic palaeontology. 1047-1065. In WASMER, M., HAUTMANN, M., HERMANN, E., WARE, D., ROOHI, G., URREH MAN, K., YASEEN, A. and BUCHER, H. 2012. Oleneki- an (Early Triassic) bivalves from the Salt Range and Surghar Range, Pakistan. Palaeontology, 55, 1043-1073.

- HERMANN, E., WARE, D., ROOHI, G., UR-REHMAN, K., YASEEN, A. and BUCHER, H. 2012. Olenekian (Early Triassic) bivalves from the Salt Range and Surghar Range, Pakistan. Palaeontology, 55, 1043-1073.

WENZ, W. 1938. Gastropoda, Teil I. 241-410. In SCHINDEWOLF, O. H. (ed.). Handbuch der Paläozoologie, Band. 6. Borntraeger, Berlin, 1639 pp.

WheELEY, J. R. and TWITCHETT, R. J. 2005. Palaeoecological significance of a new Griesbachian (Early Triassic) gastropod assemblage from Oman. Lethaia, 38, 37-45.

WHITTAKER, R. H. 1972. Evolution and measurement of species diversity. Taxon, 21, 213-251.

— and LEVIN S. A. 1975. Benchmark papers in ecology. Niche: theory and application. Dowden distributed by Halsted Press, Stroudsburg, PA, xv +448 pp.

WIGNALL, P. B. and HAllAM, A. 1992. Anoxia as a cause of the Permian/Triassic mass extinction: facies evidence from northern Italy and the western United States. Palaeogeography Palaeoclimatology Palaeoecology, 93, 21-46.

WILCKENS, R. 1909. Paläontologische Untersuchung triadischer Faunen aus der Umgebung von Predazzo in Südtirol. Verhandlungen des Naturhistorisch-medizinischen Vereins zu Heidelberg, $151 \mathrm{pp}$.

Williams, A., CARlsON, S. J., BRUNTON, C. H. C., HOLMER, L. E. and POPOV, L. 1996. A supra-ordinal classification of the Brachiopoda. Philosophical Transactions of the Royal Society of London, Series B-Biological Sciences, 351, 1171-1193.

WINCHELL, A. 1865. Descriptions of new species of fossils from the Marshall Group, and its supposed equivalent in other states. Proceedings of the Academy of Natural Sciences of Philadelphia, 1865, 109-133.

WITTENBURG, P. VON. 1908. Beiträge zur Kenntnis der Werfener Schichten Südtirols. Geologische und Palaeontologische Abhandlungen, 5, 251-289.

YIN, H. and YIN, J. 1983. Bivalves. 128-175. In YANG, Z., YIN, H., XU, G., WU, S., HE, Y., LIU, G. and YIN, J. (eds). Triassic of the South Qilian Mountains. Geological Publishing House, Beijing. [In Chinese], 381 pp.

Y Ü, W. 1975. The gastropod fossils from the Qomolangma Feng Region. Science Press, Peking, 214 pp. [In Chinese].

ZIETHEN, C. H. VON. 1830. Die Versteinerungen Württembergs. Verlag \& Lithographie des Werkes Unsere Zeit, Stuttgart, $102 \mathrm{pp}$.

ZITTEL, K. A. VON. 1895. Grundzüge der Paläontologie (Paläo-zoologie), Abteilung I, Invertebrata. Oldenburg, München \& Leipzig, 971 pp. 